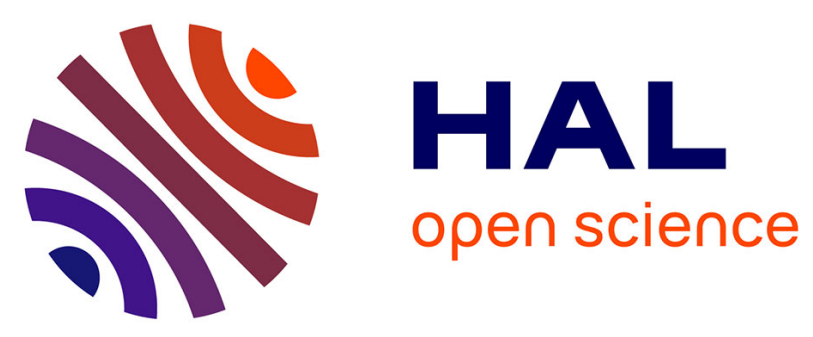

\title{
Effects of pesticide mixtures in human and animal models: an update of the recent literature
}

Virginie Rizzati, O. Briand, Hervé Guillou, Laurence Gamet-Payrastre

\section{To cite this version:}

Virginie Rizzati, O. Briand, Hervé Guillou, Laurence Gamet-Payrastre. Effects of pesticide mixtures in human and animal models: an update of the recent literature. Chemico-Biological Interactions, 2016, 254, pp.231-246. 10.1016/j.cbi.2016.06.003 . hal-02637756

\section{HAL Id: hal-02637756 \\ https://hal.inrae.fr/hal-02637756}

Submitted on 28 May 2020

HAL is a multi-disciplinary open access archive for the deposit and dissemination of scientific research documents, whether they are published or not. The documents may come from teaching and research institutions in France or abroad, or from public or private research centers.
L'archive ouverte pluridisciplinaire HAL, est destinée au dépôt et à la diffusion de documents scientifiques de niveau recherche, publiés ou non, émanant des établissements d'enseignement et de recherche français ou étrangers, des laboratoires publics ou privés.

\section{(ㅇ)(1) $\$$}

Distributed under a Creative Commons Attribution - NonCommercial - NoDerivatives| 4.0 


\section{Accepted Manuscript}

Effects of pesticide mixtures in human and animal models: An update of the recent literature

V. Rizzati, O. Briand, H. Guillou, L. Gamet-Payrastre

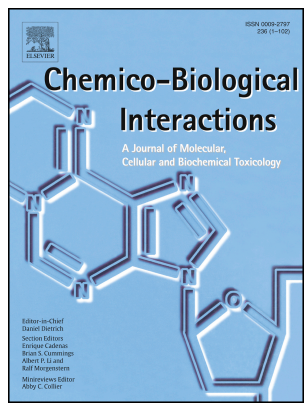

PII:

S0009-2797(16)30219-8

DOI:

10.1016/j.cbi.2016.06.003

Reference: $\quad$ CBI 7719

To appear in: Chemico-Biological Interactions

Received Date: 9 February 2016

Revised Date: 18 May 2016

Accepted Date: 3 June 2016

Please cite this article as: V. Rizzati, O. Briand, H. Guillou, L. Gamet-Payrastre, Effects of pesticide mixtures in human and animal models: An update of the recent literature, Chemico-Biological Interactions (2016), doi: 10.1016/j.cbi.2016.06.003.

This is a PDF file of an unedited manuscript that has been accepted for publication. As a service to our customers we are providing this early version of the manuscript. The manuscript will undergo copyediting, typesetting, and review of the resulting proof before it is published in its final form. Please note that during the production process errors may be discovered which could affect the content, and all legal disclaimers that apply to the journal pertain. 


\title{
Effects of pesticide mixtures in human and animal models: an update of the recent literature
}

\author{
V. Rizzati ${ }^{\mathrm{a}}$, O. Briand ${ }^{\mathrm{b}}$, H. Guillou ${ }^{\mathrm{a}}$ and L. Gamet-Payrastre ${ }^{\mathrm{a}, *}$

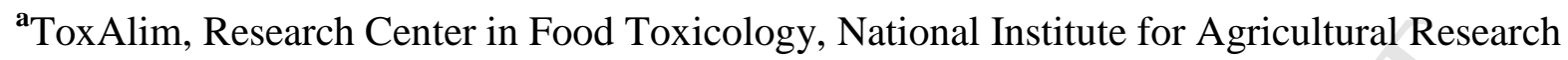 \\ (INRA) UMR 1331 INRA/INP/UPS, BP 93173, 180 chemin de Tournefeuille, Toulouse, \\ FRANCE
}

${ }^{\mathbf{b}}$ Ministère de l'agriculture, de l'agroalimentaire et de la forêt, 78 rue de Varenne, 75349 Paris, FRANCE

\section{*Corresponding author}

L. Gamet-Payrastre

ToxAlim, Research Center in Food Toxicology,

National Institute for Agricultural Research (INRA) UMR 1331 INRA/INP/UPS,

BP 93173,

180 chemin de Tournefeuille,

Toulouse, FRANCE

laurence.payrastre@toulouse.inra.fr

\section{Highlights}

- Here we provide an update of our current knowledge on pesticide cocktail effects

- $47 \%$ of the compiled studies reported an additive effect

- $36 \%$ of the compiled studies described interactions between compounds

- Pesticides interact in various ways but lead mainly to synergic effects

- Mixture effects vary according to the dose and/or physiological target

Keywords: Pesticides, Cocktail effect, Interaction, Synergy, Addition, Antagonism

\section{Abbreviations}

Dicarboximide (Dicarbo), neonicotinoid (NEO), organophosphorous (OP), organochlorine (OC), carbamate (CARB), pyrethroid (PYR), azole (AZ), imidazole (IMI), anilopyridine (APYR), benzimidazole (BenzIMI), , dithiocarbamate (DITHIOCARB), bi-pyridilium (Bi-Pyr), triazine (TRIA), triazole (TriAz), unclassified (UC): i.e. different from the other chemical 
families listed, insecticide (I), herbicide (H), fungicide (F), mixture of insecticides and herbicides $(\mathrm{I}+\mathrm{H})$, mixture of insecticides and fungicides $(\mathrm{I}+\mathrm{F})$, mixture of fungicides and herbicides $(\mathrm{F}+\mathrm{H})$, mixture of insecticides, fungicides and herbicides $(\mathrm{I}+\mathrm{F}+\mathrm{H})$.

\section{Abstract}

This review aims to provide an update on our current knowledge of the various effects of pesticide cocktails. We have collected data from studies conducted in mammalian models in vitro and in vivo that was published between 2000 and 2014. All ecotoxicological studies were voluntarily excluded. Cocktail effects were classified according to how they had been classified by each author. The frequency of the various cocktail effects and the classes and chemical families of pesticides involved in the observed effects were assessed. When focusing on the function of pesticides (i.e. herbicide, insecticide or fungicide), $46 \%$ of the mixtures contained insecticides alone, 15\% fungicides alone, and $4.5 \%$ herbicides alone. Mixtures with effects associated with neurotoxicity were mainly composed of insecticides, and most studies on the effects of fungicide mixtures (90\%) were associated with effects on endocrine regulation and/or reproduction. Dose addition was observed with each kind of mixture except herbicide combinations. In contrast, synergic interactions or greater-than-additive effects were mainly reported for insecticide mixtures. There were few examples of potentiating and antagonistic interactions. We have identified chemical families of compounds specifically involved in synergy, addition, potentiation and antagonism, and those that do not interact when combined. The chemical families identified as being involved in synergy are in agreement with data from another recently published compilation of ecotoxicological studies. For most mixtures investigated, further validation data is still needed from experiments using other compounds and other experimental models but this update provides useful information to help in human health risk assessments. 


\section{Introduction}

There is increasing concern over the health effects associated with the use of pesticides for both agricultural and residential purposes. In recent years, several studies have reported the occurrence of pesticides in a variety of matrices, such as food, water, soil, outdoor and indoor air and house dust, meaning that both general and professional populations are often exposed to compounds from different sources [1-4]. The effects of this combination of pesticides on human health need to be evaluated because the regulatory assessment of pesticide toxicity is currently only performed on selected single compounds.

One of the difficulties in assessing the effect of pesticide cocktails from the literature is the inconsistency of terms used to qualify these effects, which varies between authors. Therefore, we must first clarify that in this review we define the cocktail effects of chemical mixtures to be the result of two distinct situations: (i) where there is no direct interaction between compounds, which may or may not be associated with dose-dependent addition, and (ii) where there is an interaction between compounds. Addition is used to describe situations whereby chemicals do not interact but act together to produce effects without enhancing or diminishing each other's actions [5]. Dose addition is the term usually applied to chemicals that exert their effects through the same target and have similar modes of action. For interacting compounds, the resulting toxicities can be synergic (higher than expected from the additive effect of the doses, greater-than-additive or supra-additive effects are also classed as synergic), antagonistic (lower than expected), or potentiating (when the effect of one compound is increased by another/others). When compounds do not interact and no dose addition is observed, the toxicity of the mixture is either null or equal to that of the most efficient product(s) in the mixture.

Other reviews have already collated information on different aspects of the effects of pesticide cocktails. Carpy et al. [6] examined the available data published between 1985 and 
1998 regarding the health risk assessments of the residual concentrations of pesticide mixtures found in human food and drinking water. They reported that both synergy and antagonism occurred within the same organism depending on the organ or target, and that interactions between compounds did not appear to be a common event at these levels. In 2007, Kortenkamp et al.[5] published a review of studies that assessed endocrine disrupter (ED) mixtures in terms of additivity, antagonism or synergy. They concluded that combined effects occur even when all the individual mixture components are present at doses that are below those causing observable effects. To identify the greatest synergic effects of pesticide mixtures, Boobis et al. conducted a critical analysis of the literature from 1990 to 2008 on low-dose synergic effects of mixtures composed of a variety of chemicals (toluene, hydroquinone, pesticides, xylene) [7]. They defined synergy as a mixture response that significantly exceeds that predicted by a non-interaction model. Their search identified 90 studies that in total reported the effects of combinations of 204 different chemicals in mammals. Six of these studies provided useful quantitative estimates of synergy, and from these the authors concluded that the magnitude of synergy at low doses varied from 1.5 to 3.5 . From a number of other positive studies, they concluded that the occurrence of synergy was dose-dependent and was observed only at higher doses.

In another review, Hernandez et al. [8] assessed a number of toxicological interactions in pesticide mixtures at the molecular level and their relevance to human health. They reported several examples of cocktail effects, such as the potentiation of the toxicity of some pesticides by others (e.g. malathion by isomalation, pyrethroids (PYRs) by anticholinesterase insecticides, organophosphorous (OP) by organochlorine (OC), carbaryl by OP, and OP by triazines (TRIAs)), the synergy between PYR and carbamate (CARB) compounds, and the antagonism between TRIA herbicides and prochloraz. 
Very recently, Cedergreen [9] published a very interesting review of ecotoxicological studies that aimed to identify groups of chemicals that are overrepresented in synergic mixtures and define the molecular mechanisms underlying the observed synergy. Three groups of chemicals were studied, including pesticides, and synergic mixtures were defined as those with a minimum 2 -fold difference between the observed and predicted effect of the individual concentrations, using the concentration addition model (CA) as a reference model and including lethal and sub-lethal endpoints. Synergy occurred in 7\% of the 136 binary pesticide mixtures, which included mainly cholinesterase inhibitors or azole (AZ) fungicides, both of which are known to interfere with the metabolic degradation of other xenobiotics.

In the present review we provide an update of the recent literature on the impact of pesticide mixtures. We compiled 78 studies published between 2000 and 2014 that were conducted in mammalian model systems (both in vitro and in vivo). Ecotoxicological data were excluded although ecotoxicology and mammalian toxicity are linked to each other. From these studies, we identified those which had experimentally assessed the associated effects of simultaneous exposure to a combination of two or more pesticides and which had clearly reported the joint toxic effects of the pesticide mixtures. The cocktail effects were grouped into five classes according to the classifications made by the authors of the studies without recalculation of their results: (i) Addition, when authors clearly reported dose addition or additive effects; (ii) Synergy, when terms such as "synergistic effects", "greater-than-additive effects", or "supra-additive" were used; (iii) Antagonism, when antagonistic interactions or less-than-additive effects were reported; (iv) Potentiating interactions, when potentiation or potentiating effects were reported; or (v) No interaction, when authors reported that the cocktail effects did not exceed those of the individual compounds. Studies were not included if authors did not clearly state a dose additive effect, if they did not characterize the mixture effects as "cooperative" or "positive", if the minimum information needed to make an 
assessment was lacking, or if the term "cumulative" was used (the excluded studies are presented on Table 6 as additional data). Moreover, we also assessed the various observed effects in terms of the function and chemical family of the constituent pesticides in the mixtures. The experimental model used in each case was also taken into account (i.e. whether the study was conducted in vivo, or in vitro using cultured animal or human cells) in order to assess the utility of such studies for projecting their results to effects on human health.

\section{Materials and Methods}

\subsection{Study identification}

An electronic search using the term "pesticides mixture" was initially performed to obtain a list of relevant articles from PubMed (www.ncbi.nlm.nih.gov). This was supplemented by further searches using various combinations of the following keywords: fungicide, herbicide, insecticide, exposure, combined toxicity, combination, cocktail, cell line model, in vivo, in vitro, animal model, pesticide model, using the AND operating term to complete the search. When only abstracts were available on pubmed we either asked authors to send us a pdf copy of their article or we obtained a copy from the INIST library of the Centre Nationale de la Recherche Scientifique (CNRS). From this, we compiled a set of 78 experimental studies on the impact of pesticide mixtures that were published between 2000 and 2014. Many studies published prior to 2000 were previously incorporated into the technical report published by the European Centre for Ecotoxicology and Toxicology of Chemicals, Brussels [10]. In this document, the authors assessed studies based on the effects of co-exposure to chemicals (pesticides and other chemicals) at doses relevant to environmental human exposure. In contrast to this report, we did not select articles based upon the doses used. 


\subsection{Study selection}

Studies were excluded if:

- They were not published in English;

- They did not provide sufficient data (e.g. studies that looked at the effect of a mixture but not the individual pesticides);

- They were performed on ecotoxicological models such as insects, amphibians, or nematodes, or fish;

- The minimum information needed for assessment was lacking or the term "cumulative" was used. The studies that were excluded for this reason are listed in the supplementary data (Table 6).

Studies were included in the analysis when they complied with the following inclusion criteria:

- They had studied pesticides, including molecules currently banned;

- $\quad$ They were published in peer-reviewed journals, between 2000 and 2014;

- They had qualified any observed cocktail effects.

\subsection{Data extraction}

The following general and methodological information was abstracted from each paper: the references; pesticides evaluated; dose, duration, frequency, and manner of exposure (for in vivo studies) or cell model (for in vitro studies); parameters studied; observed effects; and the authors' conclusions in terms of whether there were synergic, antagonistic, positive or potentiating interactions, and/or whether there were any additive effects (Table 1). We also grouped the data into four categories according to the physiological functions targeted by the pesticide mixtures: (1) those associated with the central nervous system, neurotoxicity, brain or neuronal function and/or neurobehavior; (2) those associated with hematopoietic or 
immune parameters and/or inflammation (i.e. bone marrow, lymphocytes, cytokines, etc.); (3) those associated with cell biology (i.e. oxidative stress, genotoxicity, DNA damage, cell viability or proliferation) or metabolism (i.e. general, renal, hepatic, energetic and xenobiotic metabolism); and (4) those associated with parameters of reproduction, reproductive functions, and/or hormone or endocrine regulation.

\subsection{Data analysis}

The various types and combinations of pesticides (herbicides $(\mathrm{H})$, insecticides $(\mathrm{I})$, fungicides (F) or mixtures of these) were first classified according to the physiological function targeted (see Section 2.3 for details on the four categories used). Then, the percentage of each type of pesticide/pesticide mixture inducing: (i) additive effects, (ii) synergy, greater-than-additive effects, or supra-additive effects, (iii) antagonistic effects, (iv) potentiating effects or (v) no effect; was calculated, including all data that were or not deemed significant by the authors. Data were also segregated according to the model used (animal model, or cultured animal/human cells). The chemical families involved in the observed effects were also identified where possible, and their relative contributions towards the effect of each type of mixture were extracted by taking into account the magnitude of the significance of data reported by the authors. 


\section{Results and discussion}

As explained above in the section 2.2 and in the introduction, 24 studies were excluded and the various remaining 54 studies were classified as shown in Table 2, according to four distinct physiological targets and the type or function of the pesticides assessed in the mixtures: insecticides (I), herbicides $(\mathrm{H})$, fungicides $(\mathrm{F}), \mathrm{I}+\mathrm{H}, \mathrm{I}+\mathrm{F}, \mathrm{F}+\mathrm{H}$, or $\mathrm{I}+\mathrm{F}+\mathrm{H}$. From a general perspective, insecticide mixtures were the compounds most frequently evaluated in combination. Forty-six percent of the assessed mixtures we compiled from the 54 selected studies, focused on insecticide combinations, $15 \%$ on fungicide combinations, $4.5 \%$ on herbicide combinations, $12 \%$ on $\mathrm{I}+\mathrm{F}$ mixtures, $10.5 \%$ on $\mathrm{I}+\mathrm{H}$ mixtures, $4.5 \%$ on $\mathrm{H}+\mathrm{F}$ mixtures and $7.5 \%$ on $\mathrm{I}+\mathrm{F}+\mathrm{H}$ mixtures.

Mixtures assessed on parameters associated with neurotoxicity were mainly composed of insecticide compounds alone (75\%), although insecticide mixtures also affected other physiological categories (Table 2). Most studies related to the impact of fungicide mixtures (90\%) were dedicated to parameters associated with endocrine regulation and/or reproduction, with $10 \%$ reporting neurotoxic properties. The impact of herbicide mixtures was assessed less often, with two studies associating their effects with cell biology, metabolism or oxidative stress $[11,12]$ and one with reproduction and or hormonal regulation [13]. Cocktails of $\mathrm{I}+\mathrm{H}$ and I+F were mainly linked to effects on cell biology, metabolism or oxidative stress (Table 2).

\subsection{Types and frequency of cocktail effects in terms of their associated functions}

The type and frequency of the cocktail effects reported in the literature were then examined in terms of their associated physiological functions. The type of cocktail was defined here by that reported by authors; further details on the types of interaction, the magnitude of the significance were subsequently analyzed for the results presented in Section 
3.2. As shown in Table 3, forty-eight percent of the assessed mixtures were described by authors to induce effects in a dose additive manner. Moreover, $17 \%$ of the mixtures did not show any interactions between compounds. The remaining 35\% of the mixtures assessed caused effects due to interactions between compounds that were independent of a dose effect and, according to the authors, $71 \%$ were reportedly synergic, supra-additive or greater-thanadditive and $21 \%$ were antagonistic. Few were potentiating interactions (8\% of the total reported interactions) and these were observed only in vitro. For example, at non-cytotoxic concentrations, a fungicide potentiated the cytotoxicity of an insecticide in Ehrlich ascites tumor cells [14]. Recently, potentiating interactions were also reported between two insecticides and between an insecticide and a herbicide $(\mathrm{I}+\mathrm{H})$, where they increased the cytotoxicity of cultured human hepatocytes [15]. Antagonistic effects were shown to occur when combining different insecticides, different fungicides, or a mixture of herbicides and fungicides (Table 3). In rat dopaminergic cells in culture, a mixture of insecticides was found to exert an antagonistic effect on cytosolic calcium concentrations [16], and in human HepaRG liver cells, a mixture of insecticides had an antagonistic effect on parameters linked to apoptosis [17]. Recently, Savary et al. [18] reported the antagonistic effect of an insecticide mixture on the activity of Cytochrome P450 2B6 in cultured HepaRG cells. Three in vivo animal studies have also reported antagonistic interactions. In C56BL/6 mice, a herbicide antagonized the impact of a fungicide on neurochemical targets [19], and two insecticides were shown to interact in an antagonistic manner on lipoperoxidation in adult albino male Wistar rats [20]. Oral exposure of one fungicide also antagonized the increase in serum testosterone induced by another fungicide in male rats [21]. Synergic interactions were mainly observed with insecticide mixtures and were not reported for herbicide mixtures or for $\mathrm{F}+\mathrm{H}$ or $\mathrm{I}+\mathrm{F}+\mathrm{H}$ mixtures, since the few studies conducted on herbicide mixtures did not allow firm conclusions to be drawn regarding additive or non-additive effects [11, 22]. A recent study 
[23] showed that some fungicides interact synergistically regarding their anti-androgenic activity in human mammary breast cancer cell lines, according to the dose. A greater-thanadditive effect was reported by Pruett et al. [24] on interleukin production in mice exposed to a mixture of a herbicides and insecticides for 7 days. In human peripheral lymphocytes in vitro, the combination of $\mathrm{I}+\mathrm{F}$ also interacted in a possibly synergistic manner [25]. Together the compiled studies observed a dose addition with each kind of mixture except with a combination of herbicides. In addition, some studies reported pesticide mixture effects that were equivalent to the effect of the most active compound alone, inferring that there was no interaction (Table 3). This was the case with some mixtures of insecticides, fungicides, or both insecticides and herbicides or herbicides and fungicides. For example, a mixture of three insecticides did not induce synergistic or additive effects on oxidative stress compared to when they were tested alone both in vitro in rat lymphocytes and in vivo in adult rats [26, 27]. Similarly for fungicides, Prutner et al. [28] reported that the overall effects of a mixture of fungicides belonging to the same chemical class that shared either the same or opposite mechanisms of action were determined by the most potent compounds in the human adrenocortical carcinoma cell line H295. The impact of a mixture composed of two insecticides and one herbicide was also not different from that induced by the most efficient compound in vitro in primary human and mouse hepatocytes [29] as well as in vivo on hematopoietic parameters in mice [30]. Combining a herbicide with a fungicide also did not change the effect of the former on neurodegeneration in rats [31].

Overall, the large number of studies concerning insecticides allows us to draw overall conclusions following the analysis of these studies in combination. They have revealed that insecticide mixtures can lead to cocktail effects due to

(i) Dose addition (33 reports of dose addition or an additive effect: 12 in animal models, 11 in cultured human cells and 10 in cultured animal cells); 
(ii)

Interactions between compounds (24 reports). Seventeen reported synergic, greater-than-additive or supra-additive effects ( 8 in animal models, 7 in cultured human cells and 2 in cultured animal cells), 5 reported antagonistic interactions ( 3 in animal models, 1 in cultured human cells and 1 in cultured animal cells) and 2 potentiating interactions ( 1 in cultured human cells and 1 in cultured animal cells).

(iii) Being the most efficient compound of the mixture (i.e. no interaction with other pesticides in the mixture). This was reported by 12 studies: 6 in animal models, 1 in cultured human cells and 5 in cultured animal cells) (Table 3 ).

In conclusion, different combinations of insecticides were associated with different effects. Combinations of fungicide compounds led mainly to additive effects. Four studies reported such an effect in cultured human cells, two in cultured animal cells and one in an in vivo animal model (Table 3). I+H combinations were associated with synergy (one example), potentiating effects (two examples), addition (one example), and no interaction (two examples) and all studies (except those concluding a potentiating effect) were performed in animal models (Table 3). For $\mathrm{I}+\mathrm{F}$ combinations, one in vivo example was classified as having "synergic or greater-than-additive effects", one with "potentiating effects" in cultured animal cells, and three causing "addition": one from in vivo experiments and two from cultured human cells (Table 3). F+H combinations led to synergy (one example in vivo), antagonistic effects (one example in vivo), or no interaction between the fungicides and herbicides (one example in vivo and one in cultured animal cells). Mixing the three classes of pesticides only led to dose addition, as reported by three in vitro studies and one in vivo experiment (Table 3 ).

Together these data show that the function of pesticides does not necessarily determine the effects of the mixture, as the same combinations of pesticides has been found to lead to 
distinct effects. Therefore, we next focused on whether the chemical family of the pesticide, and where possible the dose and biological target, plays a role in the various types of cocktail effect.

\subsection{Types and frequency of cocktail effects in terms of the chemical family, the} experimental model, the dose.

This section compares the different chemical families of the pesticides involved in the reported cocktail effects in terms of the physiological targets described by the authors in the compiled studies and the experimental models used (Table 4). Interestingly, in most cases each specific combination was associated with only one studied physiological parameter, for example the impact of mixtures of carbamate (CARB) or organophosphorous and carbamate (OP+CARB) compounds was only reported in studies related to neurotoxicity, and mixtures of OC+TRIA compounds in studies related to immunity or haematopoiesis. The exceptions were mixtures of organoclorine (OC), OP, OP+PYR (pyrethrinoid), OP+OC and azoles (AZ,) which were associated with at least two different physiological parameters. In order to find the parameters affected in each type of cocktail mixture, we decided to overcome the distinction between the studied targets. In the following paragraphs we describe the pesticide cocktails that led to synergic, antagonistic, and additive effects, and in cases of noninteraction. Each sub-section is split into 3 parts: (i) provides a general list of the various mixtures that were described to produce this effect, the physiological parameters involved and the model used in each given situation; (ii) analyzes the combinations of compounds that gave rise to that type of effect only, according to the significance of the data provided by authors; (Table 5a) and (iii) concludes our findings and allows us to identify the chemical combinations of compounds that could be a risk to human health. Moreover the names of all the chemical families their abbreviations and the corresponding compounds discussed in the 
manuscript, as well as their functions (insecticide, herbicide or fungicide) are described in table $5 b$.

\subsubsection{Synergic pesticide mixtures}

3.2.1.1 General list of chemical families with synergic, greater-than-additive or supraadditive effects

The results in Table 4 show that synergy was observed between compounds thought to have both distinct and common mechanisms of action. In the cultured Chinese hamster ovary (CHO) cell line, a mixture of five pesticides (OP+PYR+2TriAZ (triazole)+TRIA (triazine)) induced a greater-than-additive effect (i.e. the predicted effect concentrations were higher than the observed effect concentrations) on induced androgen receptor activity [32]. In mouse neuroblastoma cells, synergy was detected between combinations of OP and pyrethrum [33]. Combinations of $\mathrm{OP}+\mathrm{CARB}, \mathrm{OC}+\mathrm{CARB}, \mathrm{OP}+\mathrm{OC}$ appeared to clearly interact in a synergic manner in vitro in human peripheral lymphocytes and AZ+dicarbo (dicarboximide) in human mammary breast cancer cells [23, 34]. In addition, a mixture of TRIA+OC had a much greater-than-additive effect on IL6 production in mice, with a $20 \%$ predicted effect for the individual effects of each compound versus $80 \%$ when assessed in combination. This was a specific effect since it did not apply to a different biological parameter (the inhibition of cJun activation) [24]. Exposing male Wistar rats to a mixture of pyrethrinoid+neonicotinoid (PYR+NEO) (delthamethrin and thiachloprid) was reported to synergistically increase genotoxicity and cytotoxicity in rat bone marrow cells [35]. A mixture of 2OP and 2OC (chlorpyrifos, monochrotophos, lindane and endosulfan) produced a synergic effect on apoptosis and the proliferative activity of rat bone marrow cells in vivo [36]. However, an in vitro experimental model in mice splenocytes and thymocytes that combined $1 \mathrm{OP}$ with $1 \mathrm{OC}$ (lindane and malathion) produced an additive effect [37, 38]. The combined effect of PYR+OP (deltamethrin and chlorpyrifos) in male Wistar rats was also synergic and this effect 
was shown to be specific for certain physiological parameters (catalase activity)[20]. Moreover, other OP+PYR mixtures (e.g. diazinon and cypermethrin) produced an additive effect on reproductive parameters in mice [39], but when assessed in mouse neuroblastoma cells in vitro were found not to interact [40]. Mixtures of anilopyridine (A-PYR) with the phenyl Pyrrole or of Neo+phenylamide produced "some degree of synergy or possible synergy" when assessing their effects on oxidative stress-related gene expression in human neuroblastoma cells [41] and on micronuclei formation in rat bone marrow or human lymphocytes, respectively [25]. Christen et al. [23] reported a clear dose-related synergic interaction between azoles and dicarboximide compounds in a binary mixture in a human mammary breast cancer cell line. The differences in synergy observed at different equieffective concentrations were suggested to be due to either the different strengths of the competing antagonistic compounds for the ligand binding site of the AR, interactions with distinct sites of the AR, or transactivation. A mixture of pyridine and CARB compounds was also reported to interact synergistically on the nigrostriatal dopaminergic system in mice [42], but no interaction was found when assessing the inflammatory processes linked to the neurodegeneration process in rats [31]. Both studies used comparable doses, with mice injected intraperitoneally twice a week for 6 weeks in the first study [42], and rats injected twice a week for 4 weeks in the second study. The different duration of exposures may explain the differential effects of this mixture.

Synergy was also observed with mixtures of compounds belonging to the same chemical family which supposedly shared a common mechanism of action (Table 4). Only a few examples are described in the following paragraph. Richardson et al. [43] showed that the sequential exposure of rats to a mixture of two OPoxon compounds (oxon metabolite of organophosphorous compounds) resulted in greater-than-additive effects on choline esterase activity at higher concentrations, whereas simultaneous exposure to the same mixture led to 
additive effects on this parameters [44]. Dose-dependent synergic interactions were also reported by Moser et al. [45] in pre-weaning and adult Long Evans rats exposed to a mixture of 7 carbamate compounds. The effects were mostly dose additive with mixture ratios based on relative potency factors (i.e. hazard-based mixtures), whereas greater-than-additive, or synergistic effects were noted when the mixture ratios used were based on amounts sold in California (i.e. were exposure based). These results were similar across various endpoints in both adults and pups. The magnitude of the synergy was up to twofold in adults and threefold in pups. In contrast, in the same animal model, Mwanza et al. [44] reported an additive effect of a mixture of carbamate compounds, however they assessed mixtures of only two carbamate compounds and used doses higher than those tested in the studies of Moser et al. Synergy between OC compounds has also been clearly reported by various authors in human cell lines (hepatic, mammary, intestinal) and primary cultured hepatocytes (Table 4). The impact of OC mixtures appears to depend on the targets studied, with a good example provided by Savary et al. [18]. These authors showed that a mixture of OC compounds in cultured human cells led to synergy in terms of a cytotoxic endpoint, addition in terms of CYP3A4 expression, and antagonism in terms of CYP2B6 activity. Moreover, [46] reported that the combination of OC compounds lindane and dieldrine led to either an additive effect on membrane depolarization or an antagonistic effect on basal calcium concentrations in the rat dopaminergic cell line PC12. Christen et al. [23] reported a dose-related synergic interaction between azole compounds in a binary mixture in a human mammary breast cancer cell line. On the other hand, in a human adrenocortical cell line, a ternary mixture of three azole compounds (epoxiconazole, propiconazole and tebuconazole) led to additive effects on the cellular endocrine potential [47]. Moreover, binary and quaternary mixtures of azole compounds induced additive effects on basal concentrations and voltage gated calcium channels in rat dopaminergic PC12 cells [48]. 


\subsubsection{Mixtures that are reported to induce only synergic effects (Table 5 a)}

Mixtures that were found to cause only synergic effects were AZ+Dicarbo, APYR+phenylpyrrole and OC+CARB in cultured human cultured cells, PYR+NEO and $\mathrm{NEO}+\mathrm{Phenylamide}$ in vivo, and $\mathrm{OP}+\mathrm{PYR}+2 \mathrm{AZ}+\mathrm{TRIA}$ in $\mathrm{CHO}$ cells. In human peripheral lymphocytes, synergic interactions between OC and CARB were confirmed by authors using the statistical method described by Marking (1977) and DeLorenzo and Serrano (2003) [34]. A joint synergic effect of $\mathrm{OP}+\mathrm{CARB}$ and $\mathrm{OC}+\mathrm{OP}$ was also confirmed but these chemical mixtures were also shown to interact in an additive manner [37, 49]. However neither the compounds nor the experimental models assessed were the same between these studies. The joint effects of the mixture of $\mathrm{AZ}$ and dicarboxymide (dicarbo) in a human mammary breast cancer cell line were calculated on the basis of the Hill regression model for each pesticide in the mixture, using the concept of concentration addition [23]. On the other hand, Coleman et al. [41] described only a small degree of interaction between A-PYR and phenylpyrrole that was reported but not calculated, so this study has been omitted for the discussion. In an animal model the joint effect of PYR and Neo was shown to be significantly greater than that of the individual compounds [35]. This synergy was also observed in animals at high concentrations (around the $\mathrm{mg} / \mathrm{kg}$ body weight) so cannot be used to estimate the human risk, and were not proved by mathematical modeling. In addition, the effect of NEO and phenylamide mixtures on micronuclei formation in the bone marrow of male rats has been suggested by authors [25]. In CHO cells, after completing concentration-response analyses of the single pesticides, mixture effect concentrations of OP+PYR+2TriAZ+TRIA were predicted by applying the principle of concentration addition (CA) [32]. For the mixture the predicted effect concentrations were found outside the $95 \%$ confidence band for the observed 
effect, and were higher than the observed effect concentrations, indicating a greater-thanadditive (synergic) effect of the mixture on DHT-induced AR activity [32].

\subsubsection{Conclusion}

Synergic interactions have been clearly reported between two insecticides belonging to the OC and CARB families of compounds (endosulfan and carbofuran) and between two fungicides belonging to the $\mathrm{AZ}$ and dicarboximide families (vinclozolin and tebuconazole/vinclozolin+ecoconazole) in human mammary breast cancer cells at low concentrations $(\mu \mathrm{M})$, suggesting that these mixtures may represent a hazard to human health. However, this needs to be confirmed in other cellular and animal models. The synergic effect of OP+PYR+2TriAZ+TRIA (terbuthylazine, bitertanol, propiconazole, cypermethrin and malathion) was significant and observed at relatively low doses but needs to be confirmed in human cell lines before these results can be projected [32] to human health risk.

\subsubsection{Antagonistic pesticide mixtures}

\subsubsection{General list of chemical families involved in antagonistic interactions}

Antagonistic interactions were reported between compounds belonging to different chemical families. For example, in rat PC12 cells, when OP (chlorpyrifos) was combined at its lower observed effect concentration (LOEC) with its OP oxon-metabolite (chlorpyrifos-oxon), no additivity effects were observed [50]. This LOEC mixture of chlorpyrifos $(0.1 \mu \mathrm{M})$ with chlorpyrifos-oxon $(1 \mu \mathrm{M})$ did not significantly inhibit the depolarization-evoked increase in $\left[\mathrm{Ca}^{2+}\right]_{\mathrm{i}}(94 \pm 3 \%, n=42, N=5)$ compared to control cells, whereas the individual compounds both inhibited it by around $25 \%$. These results suggest that these two compounds may interact in an antagonistic manner through competition for specific targets. In another study [19], authors reported an antagonistic interaction of a mixture of TriAZ and pyridine compounds (triadimefon and paraquat) in male mice orally exposed for 12 weeks to doses ranging from 2 
to $12 \mathrm{mg} / \mathrm{kg}$ body weight per day, doses which far exceed those at which humans can be exposed through food intake. Mixtures of OP and PYR compounds (deltamethrin and chlorpyrifos) given to male albino Wistar rats at doses of 1 and $5 \mathrm{mg} / \mathrm{kg}$ over 16 weeks led to synergic effects on catalase activity in brain [20], however the same studies showed that these compounds also interacted in an antagonistic manner in their effects on enzymes involved in lipoperoxidation [20]. The effects of OP+PYR mixtures therefore appear to depend on the target and the constituent compounds. Indeed, a different OP+PYR mixture (diazinon and cypermethrin) was found to exert an additive effect on the reproductive function in male mice [39], whereas the same compounds were shown to not interact when assessed in vitro in mouse neuroblastoma cells [40]. Antagonistic interactions have also been reported between compounds belonging to the same chemical family (e.g. mixtures of dicarboximide, OP or OC compounds) (Table 4). Two distinct mixtures of OC compounds (lindane and dieldrine: M1, and endosulfan and metoxychlore: M2) were shown to interact in an antagonistic manner on basal calcium concentrations (M1) or CYP2B6 activity (M2), however this antagonism was not observed on other studied parameters. Both of these studies were performed in vitro in cultured animal (M1) or human (M2) cells $[18,46]$. As described above, other OC compounds have been shown to interact in a synergic [11, 12, 18] or additive manner [18], or to not interact [51] in cultured human cells. Together these results suggest that the antagonistic interactions between OC compounds may depend upon the constituent compounds and the cell model used. Antagonistic interactions between other OP compounds (isomalathion and malathion) have also been reported in their effects on apoptosis in human hepaRG cells [17]. OP mixtures have also been reported to lead to additive effects either in vivo in an animal model or in vitro in cultured human cells $[17,52]$. Another study of OP mixtures by Ojha et al. reported no interaction in an in vivo animal model [53]. It is noteworthy that in each study reported here the compounds were different, supporting the concept that the cocktail effect 
may depend in part on the chemical family of the compound but mainly on the compound itself. Mixtures of dicarboximide were reported to interact in an antagonistic manner on serum testosterone production in male rats in only one in vivo study [21], however administration of the dicarboximide mixture has rather a cumulative effect on other androgen-sensitive end points in the pubertal male rat exceeding the response expected [21].

\subsubsection{Mixtures that are reported to induce only antagonistic interactions (Table5a)}

Mixtures of TriAZ+pyridine compounds have been reported by authors to interact in an antagonistic manner. In male C57BL/6 mice exposed to this $\mathrm{F}+\mathrm{H}$ mixture containing triadimefon (TDF50) and paraquat (PQ) for 12 weeks (at doses of 25 and $10 \mathrm{mg} / \mathrm{kg}$, respectively), authors observed that PQ prevented the increased levels of activity associated with TDF50, suggesting that there were antagonistic interactions between these compounds in vivo. However, these results were not confirmed by statistical modeling $[19,50]$.

\subsubsection{Conclusions}

For compounds producing effects suggestive of antagonistic interactions, none were clearly identified to interact only in an antagonistic manner.

\subsubsection{Potentiating pesticide mixtures}

\subsubsection{General list of chemical families involved in potentiating interactions}

The potentiating effects of pesticides in mixtures was reported in vitro in Ehrlich ascite tumor cells for OC+DTCARB mixtures at very high doses (1.2 and $0.6 \mathrm{mM}$ respectively) [14] and for mixtures of TRIA+OC or OP+OC in HepaRG cells [54] (Table4). Upon repeated longterm exposure in a HepaRG model, the effect of the OC compound endosulfan on cell impedance was potentiated when combined with the TRIA compound triazine, and was potentiated even more intensively with the OP compound chlorpyrifos, in a dose-dependent manner. It is noteworthy that mixtures of TRIA+OC or OP+OC compounds have also been 
reported to interact in an additive or synergic manner (as described in the section 3.2.1 above with other chemical compounds (e.g. lindane and malathion $[37,38]$ or atrazine and dieldrine [24]) and in other experimental models. Thus, the potentiation between TRIA+OC or OP+OC compounds may not be attributed to all compounds belonging to these classes of chemicals and may depend on the constituent compounds and/or the experimental model used.

\subsubsection{Mixtures that are reported to induce only potentiating interactions (Table 5a)}

Mixtures of OC and DTCARB compounds appear to have only potentiating interactions in terms of their effects on cytotoxicity. This effect was observed in vitro and a mechanism was proposed whereby thiram potentiates the cytotoxicity of endosulfan through excessive glutathione depletion, leading to higher oxidative stress as evidenced by the induction of reactive oxygen species (ROS).

\subsubsection{Conclusions}

Potentiating interactions between endosulfan and thiram should be confirmed at realistic doses. Before making conclusions as to the chemical families involved in this effect, other OC and DTCARB compounds must also be assessed using other models.

\subsubsection{Additive pesticide mixtures}

\subsubsection{General list of chemical families with additive effects}

The pesticide mixtures reported as having additive effects on physiological parameters are presented in Table 4. In this section we will focus on the chemical families eliciting only additive effects (and not combinations of effects) since (i) the list of mixtures reported to produce additive effects is very long, and (ii) mixtures inducing a combination of effects have been described in the above paragraphs.

3.2.4.4 Chemical families involved only in additive effects (Table 5A) 
Mixtures that have been reported to induce only additive effects are shown in Table 5 and include compounds within the same (PYR, IMI) or different chemical families (APyR+Dicarb, OP+DTCARB, OP+CARB, PYR+BenzIMI, CARB+IMI+AZ+Dicarbo, 2 Phenyl pyrroles+OP+2AZs+Phenol+Dicarbo+CARB). In human adrenocortical carcinoma cells in vitro, the combination of A-Pyr with dicarbo (i.e. cyprodinil and procymidone) was reported to act in a dose additive manner in most cases, although this was not determined using statistical modeling [28]. In this study the authors observed that this effect was dosedependent and was observed for mixtures where both compounds enhanced estrone biosynthesis but belonged to different chemical families. In an in vivo study evaluating the cocktail effects of a mixture of CARB, AZ, IMI and Dicarbo compounds [55] at doses close to the No Observable Adverse Effect Level NOAEL, authors reported that the predicted mixture effects based on dose-additivity were in good agreement with the observed effects. However, an in vivo study by Astiz et al. assessing the cocktail effects of a 2OP+DTCARB mixture reported that the simultaneous exposure to more than one compound was likely to have additive effects although these were not calculated [56]. Additive cytotoxic effects on tissues and the physiology of metabolic pathways was reported by authors upon repeated exposure of mice to BenzIMI and PYR (carbendazim with cypermethrin) at doses of 10 to 20 $\mathrm{mg} / \mathrm{kg}$ /day over 28 days [57]. In a separate study, the predicted effect concentrations of the combination of PYR+2 TriAZ compounds (cypermethrin, bitertanol, propiconazole) affecting the function of sex hormone receptors and aromatase enzyme activity in human and animal cell lines were within the $95 \%$ confidence band for the observed effects, suggestive of additive mixture effects. Isobole coefficients were estimated to give values relatively close to 1, supporting the finding of an additive mixture effect [32]. The effects of a binary mixture of OP (chlorpyrifos) with CARB (carbaryl) in rat PC12 cells was also interpreted as being additive without using any statistical approaches [50]. Another study found that a mixture of 
eleven pyrethrinoids induced the intracellular sodium concentration in mouse embryonic neuronal cells in primary culture in an additive manner. In this study, the experimental mixture data was compared with the predicted mixture concentration-response curve, and a likelihood ratio test was used to test the hypothesis of additivity using an F-distribution [58]. Assessing a binary mixture of PYR in neuronal primary culture from mouse embryos also showed an additive effect on electrophysiological properties in vitro [59], where authors compared the calculated and experimental results from binary mixture dose-response curves. A mixture of imidazoles also inhibited adrenal cortisol secretion in a monotonic, additive and predictive manner in the human adrenocortical carcinoma cell line H295R [60]. In stablytransfected human breast cancer cells, the responses of this mixture of 8 imidazoles (composed of "pure" AR antagonists: 2 Phenyl pyrroles+OP+2AZs+Phenol+Dicarbo+CARB) agreed very well with the combined effects predicted by CA.

\subsubsection{Conclusions}

The mixture effect predictions based on dose-additivity were in good agreement with the observed effects for mixtures of CARB+IMI+AZ+Dicarbo, PYR+IMI, PYR+2AZs and 2 Phenyl pyrroles+OP+2AZs+Phenol+Dicarbo+CARB. These data should be confirmed in other experimental models before they can be translated to human health risk but may help in the consideration of the impact of pesticides mixtures.

\subsubsection{Mixtures with an absence of interaction between compounds and no additive effects}

(Table 5A)

Mixtures of $\mathrm{CARB}+$ bipyridilium, $\mathrm{OP}+\mathrm{OC}+\mathrm{TRIA}$, or $\mathrm{AZ}+\mathrm{Dicarbo+DTCARB}$ were not associated with antagonistic, additive, potentiating or synergic effects and were reported to contain chemical families that did not interact when combined (Table 5) meaning that the effects of these mixtures were comparable to those of the most efficient constituents [29-31]. 
These studies were all performed in vivo in animal models. As for all types of observed effects, it is crucial that other pesticides belonging to the cited chemical classes are tested and the various mixtures are assessed in other experimental models in order to confirm these data.

\section{General discussion}

The aim of this study was to update our knowledge on the effects of pesticide mixtures by compiling studies performed in animal and human models. Taken together, our findings indicate that when combined, pesticides interact in various ways, mainly in a dose additive or synergic manner. Moreover, from our study it appears that the effect of each mixture varies according to the compound itself, the dose and the physiological target within the cell or body $[23,45]$. Overall, it seems that some combinations of chemical families of pesticides elicit effects in various categories whereas some are associated with one specific type of cocktail effect. For example, synergy was significantly observed with mixtures of compounds belonging to different chemical families (AZ+Dicarbo and OC+CARB in human cells and $\mathrm{OP}+\mathrm{PYR}+2 \mathrm{AZ}+\mathrm{TRIA}$ in cultured animal calls), additive effects with mixtures of compounds belonging to different or the same chemical families (PYR+2AZs or 3IMIs in human cells, PYR in animal cultured cells and CARB+AZ+IMI+Dicarbo in vivo in animal models). However, in each case these observations are only true for one specific compound from the identified chemical family, for example the effects of the OC+CARB mixture correspond only to mixtures of endosulfan and carbofuran. An exception is PYR +AZ+Dicarbo mixtures, whose effects have been confirmed for more than one compound from each of these chemical families. Thus, it is crucial to evaluate other compounds from the chemical families involved in these effects (AZ, OC Dicarbo, etc) before making general conclusions about the cocktail effects related to chemical families. In addition, the mixtures identified as eliciting the effects in each category should be assessed using other experimental models before their results can 
be transferred to human risk assessment. In a recent review, Cedergreen [9] defined five groups of chemicals that may be involved in synergistic interactions observed in ecotoxicological studies: OP, CARB, AZ, PYR and TRIA. These results are in agreement with our data and suggest that the focus should be on these chemical families when assessing the impact of exposure to multiple pesticide residues on human health.

The various cocktail effects discussed in this review could be explained by examining both the metabolic pathways (toxicokinetic parameters) and the cellular targets of individual pesticides (toxicodynamic parameters). Some pesticides could bind to or regulate the activity of efflux $\mathrm{ABC}$ transporters or enzymes involved in xenobiotic metabolism, leading to a change in the bioavailability and toxicity of other xenobiotics [61-63]. Moreover, two compounds may synergize by different mechanisms but have the same effect [64]. Individually, pesticides are known to exert specific effects on some cell processes and/or key proteins involved in the regulation of general metabolism, cell growth, differentiation, and survival (Figure 1). Individual pesticides can regulate the mitochondrial respiratory chain, leading to apoptosis and/or increased ROS production[65-68]. The subsequent oxidative stress, which is also part of the detoxifying process, could provoke inflammation and/or alter cell signaling enzymes involved in the control of growth and survival or induce DNA damage. Some pesticides are known to bind to or activate nuclear receptors, thereby altering the cell's general or energetic metabolism. Thus, compounds in a mixture could interact at various cellular levels (Figure 1), and it is important to take into account the multiplicity of these possible sites of interaction to explain the various mixture effects. Moreover, the chronic duration of the exposure to contaminants may add another level of complexity that must also be considered in risk evaluation. In our opinion, the complexity of the interactions involving various cellular or molecular levels is likely to lead to unpredictable effects of mixtures. 


\section{Conclusion}

Studying the impact of pesticide mixtures is of great interest to human health risk assessment processes since everyone can potentially be exposed to various cocktails of these compounds through food intake or occupational exposure. Pesticides can interact in various manners, according to the compound itself and its chemical family, the dose and the targeted parameters, and these variables can therefore lead to various effects. However, we have identified chemical families that appear to be specifically involved in one type of effect such as synergy or addition. These results need to be confirmed using other compounds in both in vivo and in vitro models to allow firm conclusions to be drawn, but they raise concerns about the safety of these pesticide cocktails since they are comparable to those often found in fruits and vegetables or used by professionals on field crops.

Acknowledgements: This work was supported by a grant from the French Ministry for Agriculture, Agrifood and Forestry.

1. Rety J., B.O., Merlo M., Volatier JL., Estimation de la contribution de l'exposition hydrique aux résidus de pesticides en France métropolitaine au regard de l'exposition alimentaire totale/ Estimation of the contribution of drinking water exposure to pesticide residues in metropolitan France in relation to the total dietary exposure. Environnement, risques et santé 2012. 11(84).

2. Orton T.G. , S.N.P.A., Arrouays D., Jolivet C.C., Villanneau E.J., MarchantB.P., Caria G., Barriuso E., Bispo A., Briand O. , Spatial distribution of Lindane concentration in topsoil across France. Science of the Total Environment, 2013. 443: p. 338-350.

3. Schummer C. , T.L., Briand O., Appenzeller B.M. , Millet M. , Application of XAD-2 resin-based passive samplers and SPME-GC-MS/MS analysis for the monitoring of spatial and temporal variations of atmospheric pesticides in Luxembourg. Environnemental Pollution 2012. 170: p. 88-94.

4. Schummer B.C., S.G., Briand O., Millet M., Appenzeller B.M.R., Determination of farm workers' exposure to pesticides by hair analysis. Toxicology letters, 2012. 210(2): p. 203-210.

5. Kortenkamp, A., Ten years of mixing cocktails: a review of combination effects of endocrinedisrupting chemicals. Environ Health Perspect, 2007. 115 Suppl 1: p. 98-105.

6. Carpy, S.A., W. Kobel, and J. Doe, Health risk of low-dose pesticides mixtures: a review of the 1985-1998 literature on combination toxicology and health risk assessment. J Toxicol Environ Health B Crit Rev, 2000. 3(1): p. 1-25.

7. Boobis, A., et al., Critical analysis of literature on low-dose synergy for use in screening chemical mixtures for risk assessment. Crit Rev Toxicol, 2011. 41(5): p. 369-83. 
8. Hernandez, A.F., et al., Toxic effects of pesticide mixtures at a molecular level: their relevance to human health. Toxicology, 2013. 307: p. 136-45.

9. Cedergreen, N., Quantifying synergy: a systematic review of mixture toxicity studies within environmental toxicology. PLoS One, 2014. 9(5): p. e96580.

10. ECETOC, effect of chemical co-exposure at doses relevant for human safety assessments. European Centre for Ecotoxicology and Toxicology of Chemicals technical report Brussels,

, 2012. 115.

11. Crepet, A., et al., The PERICLES research program: an integrated approach to characterize the combined effects of mixtures of pesticide residues to which the French population is exposed. Toxicology, 2013. 313(2-3): p. 83-93.

12. Takakura, N., et al., In vitro combined cytotoxic effects of pesticide cocktails simultaneously found in the French diet. Food Chem Toxicol, 2013. 52: p. 153-62.

13. Greenlee, A.R., T.M. Ellis, and R.L. Berg, Low-dose agrochemicals and lawn-care pesticides induce developmental toxicity in murine preimplantation embryos. Environ Health Perspect, 2004. 112(6): p. 703-9.

14. Rana, I. and T. Shivanandappa, Mechanism of potentiation of endosulfan cytotoxicity by thiram in Ehrlich ascites tumor cells. Toxicol In Vitro, 2010. 24(1): p. 40-4.

15. Nawaz, A., et al., Cellular impact of combinations of endosulfan, atrazine, and chlorpyrifos on human primary hepatocytes and HepaRG cells after short and chronic exposures. Cell Biol Toxicol, 2014. 30(1): p. 17-29.

16. Heusinkveld, H.J. and R.H. Westerink, Organochlorine insecticides lindane and dieldrin and their binary mixture disturb calcium homeostasis in dopaminergic PC12 cells. Environ Sci Technol, 2011. 46(3): p. 1842-8.

17. Josse, R., et al., Impact of isomalathion on malathion cytotoxicity and genotoxicity in human HepaRG cells. Chem Biol Interact, 2014. 209: p. 68-76.

18. Savary, C.C., et al., Interactions of endosulfan and methoxychlor involving CYP3A4 and CYP2B6 in human HepaRG cells. Drug Metab Dispos, 2014. 42(8): p. 1235-40.

19. Reeves, R., et al., Interactions of paraquat and triadimefon: behavioral and neurochemical effects. Neurotoxicology, 2003. 24(6): p. 839-50.

20. Tuzmen, M.N., N. Candan, and E. Kaya, The evaluation of altered antioxidative defense mechanism and acetylcholinesterase activity in rat brain exposed to chlorpyrifos, deltamethrin, and their combination. Toxicol Mech Methods, 2007. 17(9): p. 535-40.

21. Blystone, C.R., et al., Cumulative and antagonistic effects of a mixture of the antiandrogens vinclozolin and iprodione in the pubertal male rat. Toxicol Sci, 2009. 111(1): p. 179-88.

22. de la Rosa, P., J. Barnett, and R. Schafer, Loss of pre-B and $\lg M(+) B$ cells in the bone marrow after exposure to a mixture of herbicides. J Toxicol Environ Health A, 2003. 66(24): p. 2299313.

23. Christen, V., P. Crettaz, and K. Fent, Additive and synergistic antiandrogenic activities of mixtures of azol fungicides and vinclozolin. Toxicol Appl Pharmacol, 2014. 279(3): p. 455-466.

24. Pruett, S.B., R. Fan, and S. Oppenheimer, Greater than additive suppression of TLR3-induced IL-6 responses by administration of dieldrin and atrazine. J Immunotoxicol, 2006. 3(4): p. 25362.

25. Demsia, G., et al., Assessment of the genotoxicity of imidacloprid and metalaxyl in cultured human lymphocytes and rat bone-marrow. Mutat Res, 2007. 634(1-2): p. 32-9.

26. Ojha, A. and N. Srivastava, In vitro studies on organophosphate pesticides induced oxidative DNA damage in rat lymphocytes. Mutat Res, 2014. 761: p. 10-7.

27. Ojha, A., et al., Evaluation of DNA damage and cytotoxicity induced by three commonly used organophosphate pesticides individually and in mixture, in rat tissues. Environ Toxicol, 2011. 28(10): p. 543-52.

28. Prutner, W., et al., Effects of single pesticides and binary pesticide mixtures on estrone production in H295R cells. Arch Toxicol, 2013. 
29. Rouimi, P., et al., Impacts of low doses of pesticide mixtures on liver cell defence systems. Toxicol In Vitro, 2012. 26(5): p. 718-26.

30. Demur, C., et al., Dietary exposure to a low dose of pesticides alone or as a mixture: the biological metabolic fingerprint and impact on hematopoiesis. Toxicology, 2013. 308: p. 7487.

31. Cicchetti, F., et al., Systemic exposure to paraquat and maneb models early Parkinson's disease in young adult rats. Neurobiol Dis, 2005. 20(2): p. 360-71.

32. Kjeldsen, L.S., M. Ghisari, and E.C. Bonefeld-Jorgensen, Currently used pesticides and their mixtures affect the function of sex hormone receptors and aromatase enzyme activity. Toxicol Appl Pharmacol, 2013. 272(2): p. 453-64.

33. Axelrad, J.C., C.V. Howard, and W.G. McLean, Interactions between pesticides and components of pesticide formulations in an in vitro neurotoxicity test. Toxicology, 2002. 173(3): p. 259-68.

34. Das, P.P., A.P. Shaik, and K. Jamil, Genotoxicity induced by pesticide mixtures: in-vitro studies on human peripheral blood lymphocytes. Toxicol Ind Health, 2007. 23(8): p. 449-58.

35. Sekeroglu, V., Z.A. Sekeroglu, and E. Demirhan, Effects of commercial formulations of deltamethrin and/or thiacloprid on thyroid hormone levels in rat serum. Toxicol Ind Health, 2011. 30(1): p. 40-6.

36. Yaduvanshi, S.K., et al., Evaluation of micronuclei induction capacity and mutagenicity of organochlorine and organophosphate pesticides. Drug Metab Lett, 2012. 6(3): p. 187-97.

37. Battaglia, C.L., et al., Malathion, lindane, and piperonyl butoxide, individually or in combined mixtures, induce immunotoxicity via apoptosis in murine splenocytes in vitro. Int J Toxicol, 2010. 29(2): p. 209-20.

38. Olgun, S. and H.P. Misra, Pesticides induced oxidative stress in thymocytes. Mol Cell Biochem, 2006. 290(1-2): p. 137-44.

39. Wang, D., et al., Evidence for diazinon-mediated inhibition of cis-permethrin metabolism and its effects on reproductive toxicity in adult male mice. Reprod Toxicol, 2012. 34(4): p. 489-97.

40. Flaskos, J., et al., The effects of diazinon and cypermethrin on the differentiation of neuronal and glial cell lines. Toxicol Appl Pharmacol, 2007. 219(2-3): p. 172-80.

41. Coleman, M.D., et al., A preliminary investigation into the impact of a pesticide combination on human neuronal and glial cell lines in vitro. PLoS One, 2012. 7(8): p. e42768.

42. Thiruchelvam, M., et al., The nigrostriatal dopaminergic system as a preferential target of repeated exposures to combined paraquat and maneb: implications for Parkinson's disease. J Neurosci, 2000. 20(24): p. 9207-14.

43. Richardson, J.R., H.W. Chambers, and J.E. Chambers, Analysis of the additivity of in vitro inhibition of cholinesterase by mixtures of chlorpyrifos-oxon and azinphos-methyl-oxon. Toxicol Appl Pharmacol, 2001. 172(2): p. 128-39.

44. Mwanza, J.C., et al., Cholinesterase inhibition and depression of the photic after discharge of flash evoked potentials following acute or repeated exposures to a mixture of carbaryl and propoxur. Neurotoxicology, 2012.33(3): p. 332-46.

45. Moser, V.C., et al., Impact of chemical proportions on the acute neurotoxicity of a mixture of seven carbamates in preweanling and adult rats. Toxicol Sci, 2012. 129(1): p. 126-34.

46. Heusinkveld, H.J. and R.H. Westerink, Organochlorine insecticides lindane and dieldrin and their binary mixture disturb calcium homeostasis in dopaminergic PC12 cells. Environ Sci Technol, 2012. 46(3): p. 1842-8.

47. Kjaerstad, M.B., et al., Mixture effects of endocrine disrupting compounds in vitro. Int J Androl, 2010. 33(2): p. 425-33.

48. Heusinkveld, H.J., et al., Azole fungicides disturb intracellular $\mathrm{Ca2}+$ in an additive manner in dopaminergic PC12 cells. Toxicol Sci, 2013. 134(2): p. 374-81.

49. Wang, P., et al., Combined subchronic toxicity of dichlorvos with malathion or pirimicarb in mice liver and serum: a metabonomic study. Food Chem Toxicol, 2014. 70: p. 222-30. 
50. Meijer, M., T. Hamers, and R.H. Westerink, Acute disturbance of calcium homeostasis in PC12 cells as a novel mechanism of action for (sub)micromolar concentrations of organophosphate insecticides. Neurotoxicology, 2014.

51. Mumtaz, M.M., et al., Gene induction studies and toxicity of chemical mixtures. Environ Health Perspect, 2002. 110 Suppl 6: p. 947-56.

52. Timchalk, C., et al., Pharmacokinetic and pharmacodynamic interaction for a binary mixture of chlorpyrifos and diazinon in the rat. Toxicol Appl Pharmacol, 2005. 205(1): p. 31-42.

53. Ojha, A. and N. Srivastava, Redox imbalance in rat tissues exposed with organophosphate pesticides and therapeutic potential of antioxidant vitamins. Ecotoxicol Environ Saf, 2011. 75(1): p. 230-41.

54. Nawaz, A., et al., Cellular impact of combinations of endosulfan, atrazine, and chlorpyrifos on human primary hepatocytes and HepaRG cells after short and chronic exposures. Cell Biol Toxicol, 2013. 30(1): p. 17-29.

55. Hass, U., et al., Adverse effects on sexual development in rat offspring after low dose exposure to a mixture of endocrine disrupting pesticides. Reprod Toxicol, 2012. 34(2): p. 26174.

56. Astiz, M., M.J. de Alaniz, and C.A. Marra, Antioxidant defense system in rats simultaneously intoxicated with agrochemicals. Environ Toxicol Pharmacol, 2009. 28(3): p. 465-73.

57. Dikic, D., et al., Carbendazim impends hepatic necrosis when combined with imazalil or cypermethrin. Basic Clin Pharmacol Toxicol, 2012. 110(5): p. 433-40.

58. Cao, Z., et al., Additivity of pyrethroid actions on sodium influx in cerebrocortical neurons in primary culture. Environ Health Perspect, 2011. 119(9): p. 1239-46.

59. Scelfo, B., et al., Application of multielectrode array (MEA) chips for the evaluation of mixtures neurotoxicity. Toxicology, 2012. 299(2-3): p. 172-83.

60. Ohlsson, A., et al., Mixture effects of imidazole fungicides on cortisol and aldosterone secretion in human adrenocortical H295R cells. Toxicology, 2010. 275(1-3): p. 21-8.

61. Oosterhuis, B., et al., Specific interactions of chloroacetanilide herbicides with human $A B C$ transporter proteins. Toxicology, 2008. 248(1): p. 45-51.

62. Habibollahi, P., et al., Multi drug resistance-1 (MDR1) expression in response to chronic diazinon exposure: an in vitro study on Caco-2 cells. Bull Environ Contam Toxicol, 2011. 86(1): p. 105-9.

63. Bircsak, K.M., J.R. Richardson, and L.M. Aleksunes, Inhibition of human MDR1 and BCRP transporter ATPase activity by organochlorine and pyrethroid insecticides. J Biochem Mol Toxicol, 2013. 27(2): p. 157-64.

64. Corbel, V., et al., Synergism between insecticides permethrin and propoxur occurs through activation of presynaptic muscarinic negative feedback of acetylcholine release in the insect central nervous system. Neurotoxicology, 2006. 27(4): p. 508-19.

65. Jang, Y., et al., Chlorpyrifos induces NLRP3 inflammasome and pyroptosis/apoptosis via mitochondrial oxidative stress in human keratinocyte HaCaT cells. Toxicology, 2015. 338: p. 37-46.

66. Ramirez-Vargas, M.A., et al., Methamidophos induces cytotoxicity and oxidative stress in human peripheral blood mononuclear cells. Environ Toxicol, 2015.

67. Argentin, G., M. Divizia, and R. Cicchetti, Oxidative Stress, Cytotoxicity, and Genotoxicity Induced by Methyl Parathion in Human Gingival Fibroblasts: Protective Role of Epigallocatechin-3-Gallate. J Toxicol Environ Health A, 2015. 78(19): p. 1227-40.

68. Iorio, R., et al., Mancozeb affects mitochondrial activity, redox status and ATP production in mouse granulosa cells. Toxicol In Vitro, 2015. 30(1 Pt B): p. 438-45. 


\section{Legend to Figure 1}

Figure 1: Illustration of the various cell targets of pesticides and their effects on cell activity.

Some pesticides can bind to or regulate the activity of efflux $A B C$ transporters or enzymes involved in xenobiotic metabolism, leading to a change in the bioavailability and thus the toxicity of the other co-exposed compounds. Some pesticides are known to directly induce DNA damage. Individual pesticides are also known to exert specific effects on some cell processes and/or key proteins involved in the regulation of general metabolism, cell growth, differentiation and survival. Indeed individual pesticides may interfere with mitochondrial respiratory chain complexes or impair oxidative phosphorylation and induce mitochondrial dysfunction, leading to apoptosis and/or an imbalance in cell metabolic activity. Individual pesticides are also known to induce reactive oxygen species (ROS) production by decreasing antioxidant capacity or through increasing XME activities. The subsequent oxidative stress may interfere with inflammatory responses, leading to changes in the cell's metabolic activity and/or alter cellular signaling enzymes involved in the control of growth and survival (apoptotic pathways) or induce DNA damage. In addition, some pesticides are known to bind to or activate nuclear receptors involved in the regulation of general or energetic metabolism.

When combined, the various cellular targets of pesticides become the various possible sites of interaction. The multiplicity of these interaction sites must also be taken into account when assessing the impact of pesticide mixtures. 
Table 1A In vitro and in vivo studies related to the parameters of central nervous system, to neurotoxicity, to brain, to neuronal function, to neurobehavioral.

\begin{tabular}{|c|c|c|c|c|}
\hline Studies & $\begin{array}{l}\text { Pesticides/ } \\
\text { class// } \\
\text { chemical } \\
\text { family } \\
\end{array}$ & $\begin{array}{l}\text { Doses/ } \\
\text { Exposure way }\end{array}$ & Target & Observed effects \\
\hline \multicolumn{5}{|c|}{ Thiruchelvam, M., 2000} \\
\hline C57BL/6 mice & $\begin{array}{l}\text { Paraquat and } \\
\text { Maneb }\end{array}$ & $\begin{array}{l}-5-10 \mathrm{mg} / \mathrm{kg} \\
\text { paraquat } \\
15-30 \mathrm{mg} / \mathrm{kg} \text { maneb } \\
\text { - IP once a week for } \\
4 \text { weeks }\end{array}$ & Nigrostriatal dopamine system & $\begin{array}{l}\text { No effect of pesticide alone } \\
\text { effect of the mixture : Sustained } \\
\text { decreases in motor activity levels } \\
\text { of dopamine and metabolites and } \\
\text { dopamine turnover were } \\
\text { increased Reductions in tyrosine } \\
\text { hydroxylase immunoreactivityv } \\
\text { compounds, while having no or } \\
\text { marginal effects when } \\
\text { administered individually, can } \\
\text { produce synergistic effects when } \\
\text { given in combination }\end{array}$ \\
\hline \multicolumn{5}{|l|}{ Richardson JR 2001} \\
\hline $\begin{array}{l}\text { in vitro brain and serum } \\
\text { from male Sprague Dawley } \\
\text { rats }\end{array}$ & $\begin{array}{l}\text { Azinphos methyl } \\
\text { oxon and } \\
\text { chlorpyrifos oxon }\end{array}$ & - Dose response & $\begin{array}{l}\text { Inhibition of CHE activity by simultaneous or sequential } \\
\text { exposure to the metabolites }\end{array}$ & $\begin{array}{l}\text { Simultaneous exposure to the } \\
\text { compounds led to additive } \\
\text { effects. Sequential exposure } \\
\text { resulted in greater than additive } \\
\text { effects at the higher } \\
\text { concentrations (other factors } \\
\text { such as detoxification enzymes } \\
\text { or allosteric modulation, may be } \\
\text { involved in the departure from } \\
\text { additivity. At lower concentration } \\
\text { no departure from additivity }\end{array}$ \\
\hline \multicolumn{5}{|l|}{ Axelrad JC, 2002} \\
\hline $\begin{array}{l}\text { In vitro: } \\
\text { NB2a neuroblastoma cells }\end{array}$ & $\begin{array}{l}\text { diazinon and } \\
\text { chlorpyrifos, in } \\
\text { combination with } \\
\text { a commercial } \\
\text { formulation of the } \\
\text { compounds and, } \\
\text { independently, } \\
\text { the components } \\
\text { of that formulation }\end{array}$ & $\begin{array}{l}- \text { The compounds } \\
\text { were tested in pairs } \\
\text { in various } \\
\text { proportions } \\
\text { - } 24 \text { Hours }\end{array}$ & $\begin{array}{l}\text { neurite outgrowth measured by light microscopy and } \\
\text { quantitative image analysis. }\end{array}$ & $\begin{array}{l}\text { The combination of chlorpyrifos } \\
\text { at a maximum concentration of } \\
10 \mathrm{M} \text { and pyrethrum at a } \\
\text { maximum of } 500 \mathrm{nM} \text { produced } \\
\text { statistically significant synergism } \\
(P \text { 0.02). }\end{array}$ \\
\hline \multicolumn{5}{|l|}{ Reeves R., 2003} \\
\hline C56BL/6 male mice & $\begin{array}{l}\text { Triadimefon and } \\
\text { Paraquat }\end{array}$ & $\begin{array}{l}-25 \mathrm{and} 50 \mathrm{mg} / \mathrm{kg} \\
-10 \mathrm{mg} / \mathrm{kg} \\
- \text { IP twice a week/12 } \\
\text { weeks }\end{array}$ & Behavioral and neurochemical effects & $\begin{array}{l}\text { Mixture effect : antagonistic } \\
\text { interaction of PQ on TDF induced } \\
\text { hyperactivity PQ prevented the } \\
\text { increased levels of activity } \\
\text { associated with TDF50. }\end{array}$ \\
\hline \multicolumn{5}{|l|}{ Timchalk C, 2005} \\
\hline $\begin{array}{l}\text { In vivo: } \\
\text { Oral gavage, rats males } \\
\text { Sprague-Dawley }\end{array}$ & $\begin{array}{l}\text { Chlorpyrifos and } \\
\text { diazinon }\end{array}$ & $\begin{array}{l}\cdot 0,15,30 \text { and } 60 \\
\mathrm{mg} / \mathrm{kg} \\
-3,6,12 \text {, and } 24 \\
\text { hours postdosing }\end{array}$ & $\begin{array}{l}\text { Pharmacokinetic, pharmacodynamic assays, } \\
\text { ChE (plasma, red blood cells, brain) }\end{array}$ & $\begin{array}{l}\text { Coexposure to CPF/DZN at the } \\
\text { low dose of } 15 / 15 \mathrm{mg} / \mathrm{kg} \text { did not } \\
\text { alter the pharmacokinetics of } \\
\text { CPF, DZN, or their metabolites in } \\
\text { blood. A high binary dose of } \\
60 / 60 \mathrm{mg} / \mathrm{kg} \text { increased the }\end{array}$ \\
\hline
\end{tabular}




\begin{tabular}{|c|c|c|c|c|}
\hline & & & & $\begin{array}{l}\mathrm{C}(\mathrm{max}) \text { and } \mathrm{AUC} \text { and decreased } \\
\text { the clearance for both parent } \\
\text { compounds, likely due to } \\
\text { competition between CPF and }\end{array}$ \\
\hline & & & & $\begin{array}{l}\text { DZN for CYP450 metabolism. } \\
\text { the overall choline esterase } \\
\text { response was additive }\end{array}$ \\
\hline \multicolumn{5}{|l|}{ Cicchetti F. 2005} \\
\hline $\begin{array}{l}\text { Rats males Sprague- } \\
\text { Dawley and dopaminergic } \\
\text { (DA) neuron-glia cultures }\end{array}$ & Paraquat, Maneb & $\begin{array}{l}\text { - } 10 \mathrm{mg} / \mathrm{kg} \text { paraquat } \\
\text { - } 30 \mathrm{mg} / \mathrm{kg} \text { maneb } \\
\text { IP twice a week } / 4 \\
\text { weeks }\end{array}$ & Neuronal degeneration & $\begin{array}{l}\text { No interaction PQ with or without } \\
\text { MB induces neurodegeneration }\end{array}$ \\
\hline \multicolumn{5}{|l|}{ Tuzmen MN, 2007} \\
\hline $\begin{array}{l}\text { In vivo : adult males albino } \\
\text { Wistar rats }\end{array}$ & $\begin{array}{l}\text { Deltamethrin, } \\
\text { chlorpyrifos }\end{array}$ & $\begin{array}{l}\text { - Oral administration } \\
\text { - in food CPF } \\
1 \mathrm{mg} / \mathrm{kg} \\
\text { Deltamethrin } \\
5 \mathrm{mg} / \mathrm{kg} \\
\text { - } 16 \text { weeks }\end{array}$ & $\begin{array}{l}\text { Antioxidant enzymes activities in the } \\
\text { brain/lipoperoxidation/acetylcholine esterase }\end{array}$ & $\begin{array}{l}\text { the effects of the combination of } \\
\text { PYR and OP on LPO may be } \\
\text { due to functional, dispositional, or } \\
\text { chemical antagonism, while the } \\
\text { effects of the combination on } \\
\text { CAT activity may be synergistic. }\end{array}$ \\
\hline \multicolumn{5}{|l|}{ Jia Z, 2007} \\
\hline $\begin{array}{l}\text { In vitro: } \\
\text { Neuroblastoma SH-SY5Y } \\
\text { cell, }\end{array}$ & Endosulfan, zineb & $\begin{array}{l}: 100 \mu \mathrm{\mu M}(\mathrm{LC} 25) \\
\cdot 16 \mathrm{~h}\end{array}$ & LDH, apoptosis, necrosis , & $\begin{array}{l}\text { Toxicity of mixture higher than } \\
\text { that of individual compounds }\end{array}$ \\
\hline \multicolumn{5}{|l|}{ Flaskos J, 2007} \\
\hline $\begin{array}{l}\text { In vitro: } \\
\text { Mouse NB2a } \\
\text { neuroblastoma et C6 } \\
\text { glioma cells }\end{array}$ & $\begin{array}{l}\text { Diazinon and } \\
\text { cypermerthrine }\end{array}$ & $\begin{array}{l}\text { - Concentrations up } \\
\text { to } 10 \text { microM of } \\
\text { both compounds } \\
\text { and their mixture } \\
\text { - } 24 \text { hours }\end{array}$ & differentiation of neuronal and glial cell lines & $\begin{array}{l}\text { cypermethrin had no additional } \\
\text { effect on the inhibition of axon } \\
\text { outgrowth by diazinon. }\end{array}$ \\
\hline \multicolumn{5}{|l|}{ Wolansky MJ, 2009} \\
\hline $\begin{array}{l}\text { In vivo :males Long-Evans } \\
\text { rats }\end{array}$ & $\begin{array}{l}11 \text { pyrethroids } \\
\text { permethrin, } \\
\text { bifenthrin, } \\
\text { cypermethrin, } \\
\text { esfenvalerate, } \\
\text { deltamethrin, } \\
\text { cy- } \\
\text { cyfluthrin, } \\
\text { tefluthrin, } \lambda \text { - } \\
\text { cyhalothrin, } \\
\text { fenpropathin, } \\
\text { resmethrin, and } \\
S \text {-bioallethrin }\end{array}$ & $\begin{array}{l}\text { - Oral gavage } \\
\text { - Acute exposure (1 } \\
\text { to } 4 \mathrm{H} \text { ) each at the } \\
\text { ED30 }\end{array}$ & Motor activity & Dose additivity on motor activity \\
\hline \multicolumn{5}{|l|}{ Ojha A, 2011} \\
\hline $\begin{array}{l}\text { In vivo : mâles Wistar Rats } \\
\text { Voie orale, aigu } 24,48 \text { ou } \\
72 h \text {, chronique } 60 \text { jours, } \\
\text { Etude génotoxicité (Comet } \\
\text { assay) dans tissus (rate, } \\
\text { cerveau, rein, foie) }\end{array}$ & $\begin{array}{l}\text { Chlorpyrifos, } \\
\text { methyl parathion, } \\
\text { malathion }\end{array}$ & $\begin{array}{l}\text { - accute exposure by } \\
\text { oral gavage ( } 24, \\
48,72 \mathrm{H}) \text { at } 1 / 2 \mathrm{LD} 50 \\
(77.5 \mathrm{mg} / \mathrm{kg} \text { CPF, } \\
6,5 \mathrm{mg} / \mathrm{kg} \mathrm{MPT} \\
687,5 \mathrm{mg} / \mathrm{kg} \mathrm{MLT}) \\
\text { - Chronic exposure } \\
\text { by daily oral } \\
\text { gavage for } 60 \\
\text { days : LD50 }\end{array}$ & DNA damages in various tissues & $\begin{array}{l}\text { the damage was not the sum of } \\
\text { damage caused by individual } \\
\text { pesticide, confirming that these } \\
\text { pesticides do not potentiate the } \\
\text { toxicity of each other. }\end{array}$ \\
\hline \multicolumn{5}{|l|}{ Cao Z, 2011} \\
\hline $\begin{array}{l}\text { In vitro: } \\
\text { Mouse embryonic Neuronal } \\
\text { cells in primary culture }\end{array}$ & $\begin{array}{l}\text { deltamethrin, } \beta- \\
\text { cyfluthrin, } \\
\text { cypermethrin, } \\
\text { permethrin, } \\
\text { bifenthrin, } \\
\text { esfenvalerate, }\end{array}$ & $0.002-1 \mu \mathrm{M}$ & $\mathrm{Na}$ influx & $\begin{array}{l}\text { Additivity of the mixture: authors } \\
\text { compared the actual mixture data } \\
\text { with the predicted mixture } \\
\text { concentration-response curve, } \\
\text { and used a likelihood ratio test to } \\
\text { test the hypothesis of additivity }\end{array}$ \\
\hline
\end{tabular}




\begin{tabular}{|c|c|c|c|c|}
\hline & $\begin{array}{l}\lambda \text {-cyhalothrin, } \\
\text { tefluthrin, } \\
\text { fenpropathrin, } \\
\text { resmethrin, and } \\
S \text {-bioallethrin. }\end{array}$ & & & using an F-distribution. \\
\hline \multicolumn{5}{|c|}{ Heusinkveld HJ, 2012} \\
\hline $\begin{array}{l}\text { In vitro: } \\
\text { Rat dopaminergic PC12 } \\
\text { cells, }\end{array}$ & Lindane, Dieldrine & $\begin{array}{l}\text { - } 10 \mathrm{nM} \text { to } 10 \mu \mathrm{M} \\
\text { (calcium) } \\
10 \text { or } 100 \mu \mathrm{M} \\
\text { (viability) } \\
\text { - } 20 \text { min ou } 24 \mathrm{~h}\end{array}$ & Viability (NR), calcium homeostasis & $\begin{array}{l}\text { Differential effect of the mixture } \\
\text { antagonistic interaction on the } \\
\text { basal ca concentration and } \\
\text { additive interaction on } \\
\text { depolarization }\end{array}$ \\
\hline \multicolumn{5}{|l|}{ Moser VC, 2012} \\
\hline $\begin{array}{l}\text { In vivo : adult and } \\
\text { preweaning males Long- } \\
\text { Evans rats }\end{array}$ & $\begin{array}{l}\text { Carbaryl/propoxur } \\
\text { / methiocarb/ } \\
\text { methomy// } \\
\text { Formetanate } \\
\text { /oxamyl } \\
\text { /carbofuran }\end{array}$ & 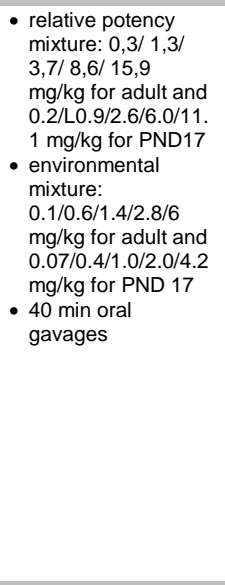 & $\begin{array}{l}\text { Behavioral and motor activity; Choline esterase activity in } \\
\text { brain and red blood cells }\end{array}$ & $\begin{array}{l}\text { Different interactive properties for } \\
\text { different mixing ratios of these } \\
\text { chemicals. II contrast, for the } \\
\text { environmental mixture, more } \\
\text { obvious greater than additive } \\
\text { responses were observed in both } \\
\text { age groups for all endpoints. This } \\
\text { synergism was generally evident } \\
\text { at all but the lowest dose tested } \\
\text { in adults and pups; The data } \\
\text { were mostly dose additive with } \\
\text { mixture ratios based on relative } \\
\text { potency factors (i.e., hazard- } \\
\text { based mixture), whereas greater- } \\
\text { than additive, or synergistic, } \\
\text { effects were noted with mixture } \\
\text { ratios based on amounts sold in } \\
\text { California (i.e., exposure based). } \\
\text { These results were similar across } \\
\text { endpoints in both adults and } \\
\text { PND17 pups. The magnitude of } \\
\text { the synergy was up to twoofold in } \\
\text { adults, and up to threefold in } \\
\text { pups. }\end{array}$ \\
\hline \multicolumn{5}{|l|}{ Scelfo B, 2012} \\
\hline $\begin{array}{l}\text { In vitro : neuronal networks } \\
\text { from } 16 \text { days old Balb/CIRC } \\
\text { murine embryos cultured on } \\
\text { Microelectrode array (MEA) }\end{array}$ & $\begin{array}{l}\text { deltamethrin or } \\
\text { permethrin alone } \\
\text { or in mixture }\end{array}$ & $\begin{array}{l}20 / 80 \%, 50 / 50 \% \text { ou } \\
80 / 20 \% \\
\text { at } 10,100 \mathrm{nM}, 1,10 \\
100 \text { ou } 300 \mu \mathrm{M}\end{array}$ & Spontaneous neuronal activity & $\begin{array}{l}\text { additive Neurotoxicity : } \\
\text { Normalized dose-response } \\
\text { curves of single chemicals and } \\
\text { binary mixtures were fitted to } \\
\text { sigmoidal shape curves with } \\
\text { values between } 0 \text { and } 1 \text { ( } 0- \\
100 \% \text { ) by using five different } \\
\text { theoretical models. Subsequently } \\
\text { the two classical approaches to } \\
\text { mixtures study, CA and IA, have } \\
\text { been applied to each of the used } \\
\text { theoretical models to compare } \\
\text { calculated and experimental } \\
\text { results from binary mixtures } \\
\text { dose-response curves }\end{array}$ \\
\hline \multicolumn{5}{|l|}{ Coleman MD, 2012} \\
\hline $\begin{array}{l}\text { In vitro: } \\
\text { Glial U251 and neuronal } \\
\text { SH-SY5Y cells }\end{array}$ & $\begin{array}{l}\text { pyrimethanil, } \\
\text { cyprodinil and } \\
\text { fludioxonil }\end{array}$ & $\begin{array}{l}62,5 \text { or } 500 \mu \mathrm{M} \\
48 \mathrm{H}\end{array}$ & $\begin{array}{l}\text { Energy metabolism ATP level apoptosis, oxidative stress } \\
\text { enzymes expression }\end{array}$ & $\begin{array}{l}\text { oxidative stress-related enzyme } \\
\text { gene expression increases } \\
\text { appeared to demonstrate some } \\
\text { degree of synergy in the } \\
\text { presence of the combination of } \\
\text { agents. }\end{array}$ \\
\hline \multicolumn{5}{|l|}{ Mwanza JC 2012} \\
\hline $\begin{array}{l}\text { in vivo in male Long Evans } \\
\text { rat }\end{array}$ & $\begin{array}{l}\text { Carbaryl and } \\
\text { propoxur }\end{array}$ & $\begin{array}{l}\text { 1:1.45 part Pro:carb } \\
\text { At } 031045 \text { and } 75 \\
\mathrm{mg} / \mathrm{kg}\end{array}$ & ChEsterase neurophysiological activity & $\begin{array}{l}\text { Dose addition on brain ChE } \\
\text { Erythrocyte ChE had larger } \\
\text { difference between acute and }\end{array}$ \\
\hline
\end{tabular}




\begin{tabular}{|c|c|c|c|c|}
\hline & & $\begin{array}{l}\text { Oral gavage } \\
\text { Acute or repeated } \\
\text { exposures (14 days) }\end{array}$ & & $\begin{array}{l}\text { repeated exposure and a slightly } \\
\text { greater deviation from dose } \\
\text { addition }\end{array}$ \\
\hline \multicolumn{5}{|c|}{ Heusinkveld HJ, 2013} \\
\hline $\begin{array}{l}\text { In vitro: } \\
\text { Rat dopaminergic PC12 } \\
\text { cells, }\end{array}$ & $\begin{array}{l}\text { Imazalil, } \\
\text { Flusilazole,flucon } \\
\text { azole, } \\
\text { Tebuconazole, } \\
\text { triadimefon, } \\
\text { Cyproconazole. }\end{array}$ & $\begin{array}{l}-0,1 \text { à } 100 \mu \mathrm{M} \\
\text { individual } \\
\text { compound } \\
\text { - IC20 binary } \\
\text { mixtures, } \\
\text { - IC10 quaternary } \\
\text { - } 20 \text { min or } 24 \mathrm{~h}\end{array}$ & $\begin{array}{l}\text { cell viability and oxidative stress and intracellular calcium } \\
\text { levels }\end{array}$ & $\begin{array}{l}\text { Additive effects on basal calcium } \\
\text { concentration and on voltage- } \\
\text { gated calcium channels }\end{array}$ \\
\hline \multicolumn{5}{|l|}{ Wang HP, 2014} \\
\hline In vivo : Wistar Rats & $\begin{array}{l}\text { chlorpyritos and } \\
\text { carbaryl } \\
1+1\end{array}$ & $\begin{array}{l}-1 / 125,1 / 501 / 20 \\
\text { LD50 } \\
\text { - } 90 \text { consecutive } \\
\text { days } \\
\text { - orally administered }\end{array}$ & $\begin{array}{l}\text { activities of serum cholinesterase (ChE) as well as } \\
\text { acetylcholinesterase (AChE) and neuropathy target } \\
\text { esterase (NTE) in nevve tissues }\end{array}$ & $\begin{array}{l}\text { independent effect in brain and } \\
\text { spinal cord, and additive effect in } \\
\text { the sciatic nerves }\end{array}$ \\
\hline \multicolumn{5}{|l|}{ Meijer M, 2014} \\
\hline $\begin{array}{l}\text { In vitro: } \\
\text { Rat PC12 cells }\end{array}$ & $\begin{array}{l}\text { Chlorpyrifos oxon } \\
+ \text { chlorryrifos, or } \\
\text { + parathion ethyl } \\
\text { and methyl , or + } \\
\text { carbaryl }\end{array}$ & $\begin{array}{l}10 \mu \mathrm{M}, 20 \min \text { Low } \\
\text { doses LOEC }\end{array}$ & Basal and depolarization evoked $\mathrm{ca}(2+) \mathrm{i}$ concentration & $\begin{array}{l}\text { Chlorpyrifoas and carbaryl } \rightarrow \\
\text { additive effect } \\
\text { Chlorpyrifos and oxon or } \\
\text { parathion } \rightarrow \text { non additive } \\
\text { interaction (competition for } \\
\text { voltage gated calcium channels) }\end{array}$ \\
\hline
\end{tabular}


Table $1 \mathrm{~B}$ In vitro and in vivo studies related to hematopoietic parameters (bone marrow, haematopoiesis, stem cells) and or immunity human lymphocytes

\begin{tabular}{|c|c|c|c|c|}
\hline Studies & $\begin{array}{l}\text { Pesticides/ } \\
\text { class// } \\
\text { chemical } \\
\text { family }\end{array}$ & $\begin{array}{l}\text { Doses/ Exposure } \\
\text { way }\end{array}$ & Target & Observed effects \\
\hline \multicolumn{5}{|l|}{ Olgun S, 2006} \\
\hline $\begin{array}{l}\text { In vitro: } \\
\text { Thymocytes (mice C57/B16), }\end{array}$ & $\begin{array}{l}\text { Lindane, Malathion, } \\
\text { Perméthrine, mixture: } \\
\text { Lin + Perm or Lin + } \\
\text { MLT }\end{array}$ & $\begin{array}{l}\text { - } 50 \text { to } 150 \mu \mathrm{M} \\
-5 \text { and } 15 \text { minutes }\end{array}$ & Oxidative stress & $\begin{array}{l}\text { Additive effect on } \\
\text { oxidative stress mixture } \\
\text { Lin + MLT }\end{array}$ \\
\hline \multicolumn{5}{|l|}{ Pruett, SB, 2006} \\
\hline In vivo $\mathrm{C} 57 \mathrm{~B} / 6 \times \mathrm{C} 3 \mathrm{HF} 1$ mice & Atrazine/dieldrine & $\begin{array}{l}\text { - } 100-200 \mathrm{mg} / \mathrm{kg} / 10-20 \\
\mathrm{mg} / \mathrm{kg} \\
\text { - IP } \\
\text { - daily for } 7 \text { days } \\
\text { (Dieldrine) : and one } \\
\text { dose on day } 7 \text { atrazine }\end{array}$ & Immunotoxicology parameters & $\begin{array}{l}\text { the effect was much } \\
\text { greater than additive on } \\
\text { IL-6 production (adding } \\
\text { the individual effects of } \\
\text { atrazine and dieldrin on } \\
\text { IL-6 production indicates } \\
20 \% \text { suppression, } \\
\text { whereas the combination } \\
\text { yields } 80 \% \text { suppression) } \\
\text { and essentially additive } \\
\text { for inhibition of the } \\
\text { activation of -JUN (a } \\
\text { component of the } \\
\text { transcription factor, AP1 }\end{array}$ \\
\hline \multicolumn{5}{|l|}{ Das, PP, 2007} \\
\hline Human peripheral lymphocytes & $\begin{array}{l}\text { Endosulfan/ } \\
\text { carbofuran/ } \\
\text { Monocrotophos }\end{array}$ & $\begin{array}{l}\text { - LC50 } 4.18 \mu \mathrm{M} / \mathrm{LC} 505.76 \\
\mu \mathrm{MM} / \mathrm{LC50} 7.5 \mu \mathrm{M} \\
\cdot \\
72 \text { heures }\end{array}$ & Genotoxicity of ten binary mixtures & $\begin{array}{l}\text { all the three mixtures } \\
\text { showed synergistic } \\
\text { toxicities }\end{array}$ \\
\hline \multicolumn{5}{|l|}{ Demsia G, 2007} \\
\hline In vitro :human Lymphocytes & $\begin{array}{l}\text { IIIdidacloprid, } \\
\text { Métalaxyl, }\end{array}$ & $\begin{array}{l}\cdot 0,1,1,5,10,50,100 \\
\mu g / m l \text { alone } \\
\cdot 10,25,50,100,200 \\
\mu g / m \text { in mixture } \\
\text { - } 72 \text { hours }\end{array}$ & $\begin{array}{l}\text { Cytogenetic end-points such as CBMN and SCE } \\
\text { induction in human lymphocytes in vitro }\end{array}$ & $\begin{array}{l}\text { Possible synergistic } \\
\text { effect }\end{array}$ \\
\hline In vivo: male Wistar rats & $\begin{array}{l}\text { Imidacloprid, } \\
\text { metalaxyl, }\end{array}$ & $\begin{array}{l}\text { - Orally exposure } \\
\text { mixture } 1: 1(1+\mathrm{M}) \\
\text { Imidacloprid } \\
22,45 \text { or } 67 \% \text { LD50 } \\
\text { Matalaxyl } 11,22,45 \% \\
\text { LD50 } \\
\text { - } 24 \text { Hours }\end{array}$ & in vivo $\mathrm{MN}$ formation in rat bone-marrow & $\begin{array}{l}\text { Possible synergistic } \\
\text { effects }\end{array}$ \\
\hline \multicolumn{5}{|l|}{ Battaglia CLR, 2010} \\
\hline $\begin{array}{l}\text { In vitro: } \\
\text { males C57/BL6 Mice splenocytes }\end{array}$ & $\begin{array}{l}\text { Lindane and } \\
\text { malathion, MLT, } \\
\text { Piperonyl } \\
\text { butoxideBo, Seul ou } \\
\text { en mélange }\end{array}$ & $<\mathrm{LC} 25$ & Cytotoxicity and cell death & $\begin{array}{l}\text { The pesticide mixture } \\
\text { Malathion and lindane } \\
\text { induced an additive } \\
\text { increase in cytoxicitity } \\
\text { compared with the } \\
\text { corresponding individual } \\
\end{array}$ \\
\hline
\end{tabular}




\begin{tabular}{|c|c|c|c|c|}
\hline \multicolumn{5}{|l|}{ Sekeroglu V, 2011} \\
\hline \multirow[t]{2}{*}{$\begin{array}{l}\text { In vivo: } \\
\text { male albino Wistar Rats, }\end{array}$} & $\begin{array}{l}\text { Commercial } \\
\text { formulation } \\
\text { Deltamethrin(Decis2,5 } \\
\text { EC, 25g/L) and } \\
\text { Thiacloprid (Clypso } \\
\text { OD 240, 240g/L) }\end{array}$ & $\begin{array}{l}\text { - acute exposure : (1 } \\
\text { gavages } / 24 h) 37,5 \% \\
\text { LD50 Deltamethrin (15 } \\
\text { mg/kg), Thiacloprid } \\
(112,5 \mathrm{mg} / \mathrm{kg}), \text { Delta + } \\
\text { Thia }(15+112,5 \mathrm{mg} / \mathrm{kg})\end{array}$ & $\begin{array}{l}\text { Genotoxicity and cytoxicity in rat bone marrow } \\
\text { cells, using mitotic index (MI), micronucleus (MN) } \\
\text { and chromosome aberrations (CA) assay }\end{array}$ & $\begin{array}{l}\text { Their results indicate that } \\
\text { the mixture of DEL and } \\
\text { THIA synergistically } \\
\text { increased the cytotoxicity } \\
\text { and genotoxicity in rat } \\
\text { bone marrow cells }\end{array}$ \\
\hline & & $\begin{array}{l}\text { - chronic exposure (1 } \\
\text { gavages per days during } \\
30 \text { days): } 7,5 \% \text { LD50 } \\
\text { Delta }(3 \mathrm{mg} / \mathrm{kg}) \text {, Thia } \\
(22,5 \mathrm{mg} / \mathrm{kg}), \text { Delta }+ \\
\text { Thia }(3+22,5 \mathrm{mg} / \mathrm{kg})\end{array}$ & & \\
\hline \multicolumn{5}{|l|}{ Demur C. 2013} \\
\hline In vivo C57 Bl6 mice & $\begin{array}{l}\text { Chlorpyrifos } \\
\text { endosulfan atrazine }\end{array}$ & $\begin{array}{l}\text { DJA } \\
\text { In food } \\
\text { From gestation until PND } \\
98\end{array}$ & $\begin{array}{l}\text { Metabolic fingerprint and haematopietic } \\
\text { parameters }\end{array}$ & No interaction \\
\hline \multicolumn{5}{|l|}{ Yaduyanshi SK, 2012} \\
\hline In vivo :male Park strain- 24h mice & $\begin{array}{l}\text { Lindane, Endosulfan } \\
\text { chlorpyrifos, } \\
\text { monochotophos }\end{array}$ & $\begin{array}{l}\cdot \text { Mixture } 0,125 \text { LD50, } \\
\text { pesticide alone } 0,25 \\
\text { LD50 } \\
\text { IP } 24 \mathrm{H}\end{array}$ & Genotoxicity (MN) and mutagenicity (Ames) & $\begin{array}{l}\text { Their results showed that } \\
\text { mixture caused a highest } \\
\text { increase in the } \\
\text { frequencies of } \mathrm{MN} \text { at the } \\
\text { dose of } 0.125 \text { and } 0.25 \\
\mathrm{mg} \text { of each pesticide } / \mathrm{kg} \\
\text { body weight compared to } \\
\text { individual pesticides. } \\
\text { authors concluded to a } \\
\text { synergistic effect }\end{array}$ \\
\hline
\end{tabular}




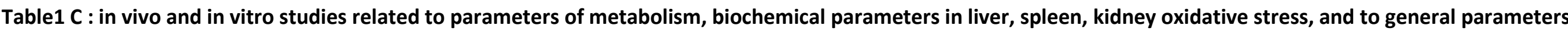
of cytotoxicity, genotoxicity, proliferation.

\begin{tabular}{|c|c|c|c|c|}
\hline Studies & $\begin{array}{l}\text { Pesticides/ class/ } \\
\text { chemical family }\end{array}$ & $\begin{array}{l}\text { Doses/ Exposure } \\
\text { way }\end{array}$ & Target & Observed effects \\
\hline \multicolumn{5}{|l|}{ Payne J, 2001} \\
\hline $\begin{array}{l}\text { In vitro: mammary } \\
\text { carcinoma cell line } \\
\text { MCF-7 }\end{array}$ & 0, p'-DDT/p, p'-DDE /, b-Hexachlorohexane/p, p' DDT & $\begin{array}{l}\cdot 1 / 10 / 5 / 4 \mathrm{nM} \\
\cdot 7 \text { days }\end{array}$ & $\begin{array}{l}\text { the induction of cell } \\
\text { proliferation }\end{array}$ & $\begin{array}{l}\text { Synergistic effect when taking } \\
\text { into account the most efficient } \\
\text { compound additive effect } \\
\text { according to mathematical } \\
\text { modeling IA ou CA }\end{array}$ \\
\hline \multicolumn{5}{|l|}{ Astiz M, 2009} \\
\hline $\begin{array}{l}\text { In vivo : } \\
\text { male Wistar rats, }\end{array}$ & $\begin{array}{l}\text { Dimethoate, Zineb, glyphosate, binary and ternary } \\
\text { mixtures }\end{array}$ & $\begin{array}{l}\text { - } 1 / 250 \text { LD50 } \\
\text { IP } \\
\text { - } 3 \text { times a week/5 } \\
\text { weeks }\end{array}$ & $\begin{array}{l}\text { Oxidative stress in liver } \\
\text { kidneys brain and } \\
\text { plasma }\end{array}$ & $\begin{array}{l}\text { Additive effects for the binary } \\
\text { or ternary mixture }\end{array}$ \\
\hline \multicolumn{5}{|c|}{ Rana I and Shivanandappa T 2010} \\
\hline $\begin{array}{l}\text { In vitro Ehrlich ascites } \\
\text { tumor cells }\end{array}$ & Thiram and endosulfan & $\begin{array}{l}-0.5 \text { to } 1.5 \mathrm{mM} \\
\text { endosulfan and from } 2 \\
\text { to } 8 \mathrm{mM} \text { thiram } \\
\text { - Mixture thiram } 0.6 \mathrm{mM} \\
\text { and } 1.12 \mathrm{mM} \\
\text { endosulfan }\end{array}$ & $\begin{array}{l}\text { Glutathione level ROS } \\
\text { Cytotoxicty }\end{array}$ & $\begin{array}{l}\text { Very high doses potentiating } \\
\text { cytotoxicity }\end{array}$ \\
\hline \multicolumn{5}{|l|}{ Ojha A, 2011} \\
\hline $\begin{array}{l}\text { In vivo: } \\
\text { Adult male albino } \\
\text { Wistar rats }\end{array}$ & Chlorpyrifos, malathion, parathion & $\begin{array}{l}\cdot 0,25 \text { LD50 } \\
\text { : 2 days } \\
\text { - oral gavages }\end{array}$ & $\begin{array}{l}\text { Glutathione } \\
\text { homeostasis and } \\
\text { oxidative status in liver } \\
\text { kidneys spleen and } \\
\text { brain. }\end{array}$ & $\begin{array}{l}\text { selected OP pesticides have } \\
\text { no interactive toxicity }\end{array}$ \\
\hline \multicolumn{5}{|l|}{ Rouimi P, 2012} \\
\hline $\begin{array}{l}\text { In vitro: } \\
\text { Mouse and human } \\
\text { hepatocytes in } \\
\text { primary culture }\end{array}$ & Atrazine, Chlorpyrifos, Endosulfan, & $\begin{array}{l}\bullet 0,1,1,10 \mu \mathrm{M} \\
\bullet 24 \mathrm{~h}\end{array}$ & maccroarrays & No interaction \\
\hline \multicolumn{5}{|l|}{ Dikic D, 2012} \\
\hline $\begin{array}{l}\text { In vivo :male and } \\
\text { female Swiss mice }\end{array}$ & Imazalil (I), Cypermethrin (Cy), Carbendazim (Ca) & 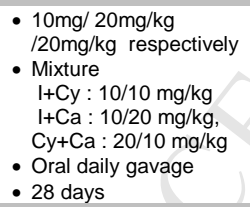 & $\begin{array}{l}\text { Liver and biochemical } \\
\text { parameters }\end{array}$ & $\begin{array}{l}\text { Additive effect for } \mathrm{Ca}+\mathrm{I} \text { or } \mathrm{Ca}+ \\
\mathrm{Cy}\end{array}$ \\
\hline \multicolumn{5}{|l|}{ Nawaz A, 2013} \\
\hline In vitro: HepaGR cells & $\begin{array}{l}\text { Binary and ternary mixture of endosulfan atrazine and } \\
\text { chlorpyrifos }\end{array}$ & $\begin{array}{l}-1,10 \text { et } 25 \mu \mathrm{MM} 50,75 \\
\text { or } 100 \mu \mathrm{M} \\
\text { Equimolar concentration } \\
\text { in the mixture } \\
\text { - Chronic and acute (2 } \\
\text { weeks or } 24 \text { hours) }\end{array}$ & $\begin{array}{l}\text { cytotoxicity gene } \\
\text { metabolism Real-Time } \\
\text { Cell IImedance }\end{array}$ & $\begin{array}{l}\text { Endosulfan potentiate the } \\
\text { effect of the other pesticides }\end{array}$ \\
\hline \multicolumn{5}{|c|}{ Takakura N, 2013} \\
\hline $\begin{array}{l}\text { In vitro: } \\
\text { Caco2 and HepG2 } \\
\text { cells }\end{array}$ & $\begin{array}{l}7 \text { mixtures } \\
\mathrm{C} 1: 3 \text { fongicides } \\
2 \text { insecticides }\end{array}$ & 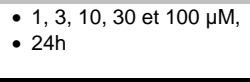 & $\begin{array}{l}\text { Cytotoxicity. evaluation } \\
\text { of the ombined effects } \\
\text { of the two most }\end{array}$ & $\begin{array}{l}\text { For the cocktail composed of } \\
\text { dichlorodiphenyltrichloroethane } \\
\text { (DDT) and dieldrin, the }\end{array}$ \\
\hline
\end{tabular}




\section{C2:}

2 insecticides 1 erbicide
C3:

4 fongicides

1 insecticide

1 herbicide
C4:
2 fongicides

2 fongicides
3 insecticides

C5 ;

2 insecticides (OC)

C6 1 herbicide un régulateur de croissance

cytotoxic cocktails by

measured effects of the the additive effect estimated by

mixtures with the the two concepts. Furthermore,

predictions based on apoptosis induction was higher

concepts-independent predicted by summing the

action (IA) and effects of DDT and dieldrin.

concentration addition Thus, some supra-additive

toxicity was found in the DD

\section{Crepet A, 2013}

vitro : rat and
human hepatocytes in

primary culture and

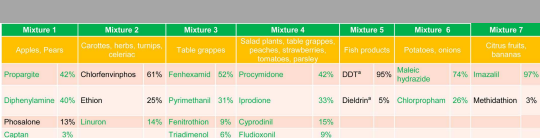

$\begin{array}{ll}\text { - } 1 \text { to } 100 \mu \mathrm{MM}, & \begin{array}{l}\text { Cytotoxicity, oxidative } \\ \text { stress, genotoxicity, } \\ \text { apoptosis, PXR }\end{array}\end{array}$

$\begin{array}{ll}\text { Cytotoxicity, oxidative } & \text { OC (mixture 5) greater than } \\ \text { stress, genotoxicity, } & \text { additive effect on cytotoxicity. }\end{array}$

apoptosis, PXR

impedance

\section{Josse R, 2014}

In vitro :HepaRG cells Isomalathion (isoMLT) and malathion (MLT)

\section{Cytotoxicity viability,}

Additive genotoxic effect and

$0,05,5,10,25,50 \mu \mathrm{M} \quad$ genotoxicity, oxidative $\quad \begin{array}{ll}\text { Additive genonistic effect on } \\ \text { stress }\end{array}$

- mixture MLT//soMLT
$25 / 0,05,25 / 5,10 / 10$,

- $24 \mathrm{~h}$

Savary CC

2014

Endosulfan and metoxychlore 
Table $1 \mathrm{D}$ : In vitro and in vivo studies related to parameters linked to reproduction, sexual hormones level, hormone receptor

\begin{tabular}{|c|c|c|c|c|}
\hline Studies & $\begin{array}{l}\text { Pesticides/ class/ } \\
\text { chemical family }\end{array}$ & Doses/ Exposure way & Target & $\begin{array}{l}\text { Observed } \\
\text { effects }\end{array}$ \\
\hline \multicolumn{5}{|c|}{ Mumtaz MM, 2002} \\
\hline $\begin{array}{l}\text { In vitro: HeLa } \\
\text { cells } \\
\text { cotransfected } \\
\text { with an } \\
\text { expression } \\
\text { vector encoding } \\
\text { estrogen } \\
\text { receptor and an } \\
\text { estrogen- } \\
\text { responsive } \\
\text { chloramphenicol } \\
\text { aceytltransferase } \\
\text { (CAT) reporter } \\
\text { plasmid }\end{array}$ & DDT, DDD, aldrin, dieldrine, endrine & $\begin{array}{l}\bullet 0 ; 0,001 ; 0,01 ; 0,1 ; 1 \text { et } 10 \mu \mathrm{M} \text { binary mixture } \\
\cdot 18 \text { hours }\end{array}$ & $\begin{array}{l}\text { transcriptional } \\
\text { activation of an } \\
\text { estrogen- } \\
\text { responsive } \\
\text { reporter gene } \\
\text { in transfected } \\
\text { HeLa cells }\end{array}$ & $\begin{array}{l}\text { no detectable } \\
\text { estrogenic activity } \\
\text { for any of the six } \\
\text { organochlorines } \\
\text { tested singly. no } \\
\text { synergistic } \\
\text { interactions } \\
\text { among } \\
\text { combinations of } \\
\text { these pesticides }\end{array}$ \\
\hline \multicolumn{5}{|c|}{ Greenlee AR, 2004} \\
\hline $\begin{array}{l}\text { In vivo Murin } \\
\text { preimplantation } \\
\text { embryos }\end{array}$ & $\begin{array}{l}\text { - dicamba/pendimethalin } \\
\text { - Dicamba/2,44-D/atrazine } \\
\text { Chlorothaloni//mancozeb/diquat } \\
\text { - atrazine/metolachlor/2,4-D/ammonium nitrate } \\
\text { - Chlorpyrifos/terbufos/ } \\
\text { permethrin } \\
\text { - Dicamba/ 2,4-D/MCPP }\end{array}$ & $\begin{array}{l}\cdot 0.03 / 0.04 \mu \mathrm{g} / \mathrm{ml} \\
\bullet 0.03 / 0.01 / 0.03 \\
\bullet 0.015 / 0.003 / 0.0022 \\
\cdot 0.035 / 0.1 / 0.01 / 1 \\
\cdot 0.003 / 0.0001 / 0.05 \\
\cdot 0.03 / 0.01 / 0.0005\end{array}$ & $\begin{array}{l}\text { effects on } \\
\text { mouse } \\
\text { preimplantation } \\
\text { embryo } \\
\text { development, a } \\
\text { period } \\
\text { corresponding } \\
\text { to the first 5-7 } \\
\text { days after } \\
\text { human } \\
\text { conception }\end{array}$ & $\begin{array}{l}\text { Mixtures showed a } \\
\text { pattern of injury } \\
\text { similar to } \\
\text { pesticides tested } \\
\text { individually }\end{array}$ \\
\hline \multicolumn{5}{|c|}{ Valeron PF, 2009} \\
\hline $\begin{array}{l}\text { In vitro: } \\
\text { Human } \\
\text { mammary } \\
\text { epithelial cells } \\
\text { (HMEC) }\end{array}$ & $\mathrm{p}, \mathrm{p}^{\prime}-D D T / \mathrm{o}, \mathrm{p}^{\prime}-D D E / \mathrm{p}^{\prime} \mathrm{p}^{\prime}-D D E, \mathrm{p}, \mathrm{p}^{\prime}-D D D /$ aldrine/ dieldrine & $\begin{array}{l}-0.46 / 1.43 / 1.08 / 1.33 / 0.2 / 0.035 \\
1 \times, 100 \times 500 \text { and } 1000 x \text { the serum concentration } \\
\cdot 96 \text { hours }\end{array}$ & $\begin{array}{l}\text { Cytotoxiccity } \\
\text { viability } \\
\text { Gene } \\
\text { expression }\end{array}$ & $\begin{array}{l}\text { Additive effect of } \\
\text { the mixture on cell } \\
\text { viability }\end{array}$ \\
\hline \multicolumn{5}{|c|}{ Blystone, CR 2009} \\
\hline $\begin{array}{l}\text { male Sprague } \\
\text { Dawley Rats }\end{array}$ & $\begin{array}{l}\text { Vinclozoline } \\
\text { Iprodione }\end{array}$ & $\begin{array}{l}-0 / 10 / 30 / 50 / 100 \mathrm{mg} / \mathrm{kg} / \mathrm{J} \\
50 \mathrm{mg} / \mathrm{kg} / \mathrm{J} \\
\text { - Oral gavage from PND } 23 \text { to PNDJ55-57 }\end{array}$ & $\begin{array}{l}\text { Male rat } \\
\text { development } \\
\text { The age at } \\
\text { puberty } \\
\text { (preputial } \\
\text { separation } \\
\text { [PPS]), organ } \\
\text { weights, } \\
\text { serum } \\
\text { hormones, } \\
\text { and ex vivo } \\
\text { testis steroid } \\
\text { hormone } \\
\text { production }\end{array}$ & $\begin{array}{l}\text { Serum } \\
\text { testosterone } \\
\text { increased from } \\
\text { vinclozolin } \\
\text { exposure but } \\
\text { iprodione } \\
\text { significantly } \\
\text { decreased this } \\
\text { effect with the } \\
\text { effect of iprodione } \\
\text { being most } \\
\text { prominent when } \\
\text { combined with } \\
\text { vinclozolin at } 60 \\
\text { mg/kg/day }\end{array}$ \\
\hline \multicolumn{5}{|c|}{ Kjaerstad MB, 2010} \\
\hline $\begin{array}{l}\text { In vitro : human } \\
\text { adrenocortical } \\
\text { carcinoma cell }\end{array}$ & $\begin{array}{l}\text { imidazoles (econazole, ketoconazole, miconazole, } \\
\text { prochloraz) } \\
\text { and triazoles (epoxiconazole, propiconazole, }\end{array}$ & $\begin{array}{l}\text { - } 4 \text { equimolar mixtures } \\
(0,025 \text { à } 50 \mu \mathrm{M}) \\
\text {. } 48 \text { Hours }\end{array}$ & $\begin{array}{l}\text { endocrine } \\
\text { potential } \\
\text { (transcriptional }\end{array}$ & $\begin{array}{l}\text { When predicting } \\
\text { the effect of the } \\
\text { mixture of the }\end{array}$ \\
\hline
\end{tabular}




\begin{tabular}{|c|c|c|c|c|}
\hline line $H 295 \mathrm{R}$ & tebuconazole) & & $\begin{array}{l}\text { activation AR, } \\
\text { estradiol and } \\
\text { testosterone } \\
\text { levels }\end{array}$ & $\begin{array}{l}\text { azole fungicides } \\
\text { on testosterone } \\
\text { production, the } \\
\text { shape of the } \\
\text { predicted curve } \\
\text { was different from } \\
\text { the observed } \\
\text { effect curve but, } \\
\text { the predicted } \\
\text { curve was } \\
\text { however, close to } \\
\text { the observed } \\
\text { values suggesting } \\
\text { additivity }\end{array}$ \\
\hline \multicolumn{5}{|c|}{ Perobelli JE, 2010} \\
\hline $\begin{array}{l}\text { In vivo: Rats } \\
\text { Lewis males } \\
\text { pesticides }\end{array}$ & Dicofol/dieldrine/endosulfan/permethrine/dichlorvos/mixture & $\begin{array}{l}\text { - LOEL/LOAEL/LEL/ } \\
\text { - In the diet } \\
\cdot 8 \text { weeks }\end{array}$ & $\begin{array}{l}\text { Reproductive } \\
\text { toxicity }\end{array}$ & $\begin{array}{l}\text { Additive effect or } \\
\text { no interaction } \\
\text { according to the } \\
\text { studied } \\
\text { parameters }\end{array}$ \\
\hline \multicolumn{5}{|c|}{ Ohlsson , 2010} \\
\hline $\begin{array}{l}\text { In vitro: } \\
\text { adrenocortical } \\
\text { carcinoma cell } \\
\text { line } \mathrm{H} 295 \mathrm{R}\end{array}$ & Prochloraz, ketoconazole, Imazalil & $\begin{array}{l}\text { - Single compounds } 0,003,0,01,0,03,0,1,0,3,1,3,10 \mu \mathrm{M}, \\
\text { binary mixture: } 1: 1(0,06 \text { or } 0,2,2 \mathrm{M}) \\
\text { - Ternary mixture } 1: 1: 1(0,003,0,009,0,03,0,09,0,3,0,9,3 \text { ou } \\
9 \mu \mathrm{M}) \\
\text { - } 24 \text { hours }\end{array}$ & $\begin{array}{l}\text { secretion of } \\
\text { cortisol and } \\
\text { aldosterone } \\
\text { and the effects } \\
\text { on } \\
\text { steroidogenic } \\
\text { gene } \\
\text { expression. }\end{array}$ & $\begin{array}{l}\text { - /Additive effect } \\
\text { on the secretion } \\
\text { of cortisol }\end{array}$ \\
\hline \multicolumn{5}{|l|}{ Hass U, 2012} \\
\hline $\begin{array}{l}\text { In vivo: female } \\
\text { Han-tac } \\
\text { rats }\end{array}$ & $\begin{array}{l}\text { epoxiconazole, mancozeb, prochloraz, tebuconazole and } \\
\text { procymidone }\end{array}$ & $\begin{array}{l}\text { - Doses closed to NOAEL for single pesticide } \\
\text { - } 14,6,29,2,43,8 \mathrm{mg} / \mathrm{kg} / \mathrm{j} \text { for the mixture } \\
\text { - Daily gavage during gestation }(7 \text { to } 21) \text { and PND1 to } 16\end{array}$ & $\begin{array}{l}\text { Sexual } \\
\text { development in } \\
\text { rat offspring }\end{array}$ & $\begin{array}{l}\text { Severe mixture } \\
\text { effects on on } \\
\text { gestation length, } \\
\text { nipple retention } \\
\text { and genital } \\
\text { malformations } \\
\text { were seen a d dose } \\
\text { levels where the } \\
\text { individual } \\
\text { pesticides caused } \\
\text { no or smaller } \\
\text { effects when given } \\
\text { alone. Generally, } \\
\text { the mixture effect } \\
\text { predictions based } \\
\text { on dose-additivity } \\
\text { were in good } \\
\text { agreement with } \\
\text { the observed } \\
\text { effects. }\end{array}$ \\
\hline \multicolumn{5}{|c|}{ Wang D, 2012} \\
\hline $\begin{array}{l}\text { In vivo: } \\
\text { Male Sv/129 } \\
\text { mice }\end{array}$ & Diazinon, cis-permethrin, & $\begin{array}{l}\text { - } 10 \text { and } 90 \mu \mathrm{mol} / \mathrm{kg} / \mathrm{day} \text { respectively } \\
\text { : } 100 \mu \mathrm{mol} / \mathrm{kg} / \mathrm{day} \text { mixture }(30 \mathrm{mg} / \mathrm{kg} / \mathrm{day} \text { approcximatively } \\
\text { - Gavage } 6 \text { weeks }\end{array}$ & $\begin{array}{l}\text { Reproductive } \\
\text { toxicity }\end{array}$ & $\begin{array}{l}\text { Diazinon inhibited } \\
\text { cis-permethrin } \\
\text { metabolism. } \\
\text { additif effect of the } \\
\text { mixture on the } \\
\text { reproductive } \\
\text { function }\end{array}$ \\
\hline \multicolumn{5}{|l|}{ Orton F 20} \\
\hline $\begin{array}{l}\text { In vitro MDA-kb2 } \\
\text { cells human } \\
\text { breast cancer } \\
\text { cells stably }\end{array}$ & $\begin{array}{l}\text { Fludioxonil; fenhexamid, orthophenyl phenol, imazalil, } \\
\text { tebuconazole, dimethomorph, methiocarb, } \\
\text { pirimiphosmethyl (8 mix ar agonist) cypridonyl, } \\
\text { pyrimethanil, vinclozolin, chlorpropham, linuron (5 mix AR }\end{array}$ & $1.17 \mathrm{nM}-150 \mu \mathrm{M}$, & $\begin{array}{l}\text { Antagonist } \\
\text { activity }\end{array}$ & $\begin{array}{lr}\text { Widely } & \text { used } \\
\text { pesticides } & \text { act } \\
\text { additively in } & \text { AR } \\
\text { vitro as } & \text { AR } \\
\end{array}$ \\
\hline
\end{tabular}




\begin{tabular}{|c|c|c|c|c|}
\hline $\begin{array}{l}\text { transfected with } \\
\text { a fireffy } \\
\text { luciferase } \\
\text { reporter gene } \\
\text { that is driven by } \\
\text { an androgen- } \\
\text { response } \\
\text { element- } \\
\text { containing } \\
\text { promoter }\end{array}$ & antagonist) and all pest (mix 13) & & & antagonists \\
\hline \multicolumn{5}{|c|}{ Overgaard, 2013} \\
\hline $\begin{array}{l}\text { In vivo: females } \\
\text { rats Han-tac: } \\
\text { WH }\end{array}$ & $\begin{array}{l}\text { epoxiconazole, mancozeb, prochloraz, tebuconazole and } \\
\text { procymidone }\end{array}$ & 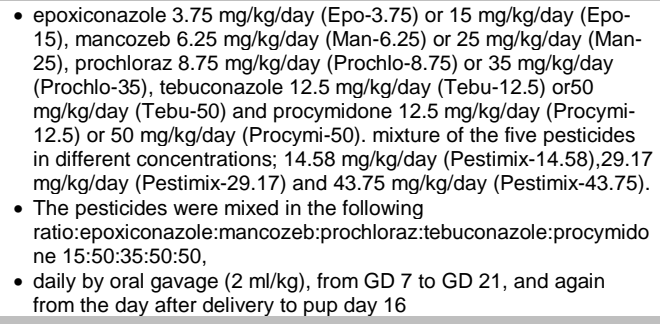 & $\begin{array}{l}\text { on kisspeptin } \\
\text { neurons in the } \\
\text { rat } \\
\text { hypothalamus }\end{array}$ & No additive effects \\
\hline \multicolumn{5}{|c|}{ 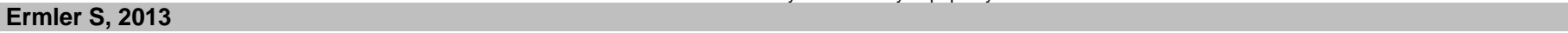 } \\
\hline $\begin{array}{l}\text { In vitro: } \\
\text { CHO-K1 cells }\end{array}$ & $\begin{array}{l}\text { albendazole, benomyl, carbendazim, } \\
\text { flubendazole, mebendazole, oxibendazole, thiabendazole, } \\
\text { albendazole oxyde }\end{array}$ & - Dose 10-7M & $\begin{array}{l}\text { MTT, } \\
\text { cytochalasin } \\
\text { blocked } \\
\text { micronucleus } \\
\text { assay }\end{array}$ & $\begin{array}{l}\text { Additive effect of } \\
\text { the mixture of all } \\
\text { pesticides }\end{array}$ \\
\hline \multicolumn{5}{|c|}{ Prutner W, 2013} \\
\hline $\begin{array}{l}\text { In vitro: } \\
\text { Human } \\
\text { adrenocortical } \\
\text { carcinoma cell } \\
\text { line H295R }\end{array}$ & $\begin{array}{l}\text { cyprodinyl, pyrimethanil, iprodione, procymidone, } \\
\text { myclobutanil, tebuconazoole, azoxystrobin, kresoxim- } \\
\text { méthyl, methomyl, captan }\end{array}$ & $\begin{array}{l}\text { : from } 0,01 \text { to } 100 \mu \mathrm{M} \\
24 \mathrm{~h}\end{array}$ & $\begin{array}{l}\text { Estrone } \\
\text { production }\end{array}$ & $\begin{array}{l}\text { - Combination of } \\
\text { fungicides } \\
\text { enhancing } \\
\text { estrone } \\
\text { biosynthesis and } \\
\text { belonging to the } \\
\text { same chemical } \\
\text { group, --- the } \\
\text { effect of the } \\
\text { more potent } \\
\text { compound in the } \\
\text { mixture } \\
\text { - Combination of } \\
\text { fungicides } \\
\text { enhancing } \\
\text { estrone } \\
\text { biosynthesis and } \\
\text { belonging to } \\
\text { different } \\
\text { chemical groups } \\
\text {--> a dose addi- } \\
\text { tivity cypro + } \\
\text { procy } \\
\text { - two fungicides } \\
\text { having opposing } \\
\text { effects on } \\
\text { estrone } \\
\text { biosynthesis--- } \\
\text { effect of the } \\
\text { compound } \\
\text { inhibiting } \\
\text { estrone } \\
\text { biosynthesis. }\end{array}$ \\
\hline
\end{tabular}




\section{In vitro:}

CHO-K1 cells,

using luciferase

assays

2-methyl-4-chlorophenoxyacetic acid mesosulfuron-methyl, metsulfuron-methyl,

pothioconazolo mancozeb, cypermethrin, tau lluvalinate, malathion

and the metabolite ethylene thiourea (ETU)
- ER et AR transactivation : mixture $55.10^{-12}$ to $2,5.10 \mathrm{M}$

Aromatase activity : mixture $5.10^{-8}$ to $2,5.10^{-4} \mathrm{M}$

The estrogenic and antiestrogenic activities of the pesticides were

by Prof. M. Pons. France), derived from the human breast

adenocarcinoma MCF-7 cell line, carrying an estrogen response

element luciferase reporter vector The androgenic and

antiandrogenic activites of the pesticides were assessed using the

Chemen

aromatase activity
JEG-3 cell line

- no case a

synergistic effect
was observed

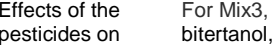

$\begin{array}{ll}\text { pesticides on } & \text { bitertanol, } \\ \text { ER and AR } & \text { propiconazole, }\end{array}$

After completing predicted effect

concentration-
response analyses concentrations

of the single

pesticides, mixture $\quad 95 \%$ confidence
effect

concentrations observed effects,

were predicted as as suggesting
described (Birkhoj

et al. 200 additive mixture

2004 and Kruger effects. Isobole

et al., 2008) by coefficients were

principle of values relatively

close to 1 ,

supporting the

addition (CA).
Briefly, this model

relies on the
assumption that

mixture

finding of an
additive mixture

effect . For Mix5,

(terbuthylazine,

bitertanol,

which do not
interact, difer only

in potency and

can be considered cypermethrin,

malathion), the
predicted effect

concentrations

were found

confidence band

for the observed

effect, and were

higher than
observed effect

observed effect

indicating an effect

more than additive

(synergistic) of the
mixture on $D H T$ -

induced $A R$

activity

Christen V, 2014
In vitro MDA kb2 dicarboximide and azoles
cells

cells
Anti androgenic

activity Interactions in
mixtures follow the
CA model. CA model.
However, a high synergistic

interactions

occurred..Additivity
and synergy occur

according to the

dose $(A Z+A Z$ and 
Table 2. Classification of results from studies listed in Table 1 (available in the supplementary data) investigating the effects of pesticides mixtures. Values in red show the number of mixtures assessed in each category. Some references appear many times in the table where authors have assessed different mixtures. In brackets the percentage values.

\begin{tabular}{|c|c|c|c|c|c|c|c|}
\hline 67 mixtures assessed in total & $\begin{array}{c}\text { Mixture of } \\
\text { insecticides } \\
\text { (I) } \\
31(46 \%)\end{array}$ & $\begin{array}{l}\text { Mixture of } \\
\text { herbicides } \\
\quad(\mathrm{H}) \\
3(4.5 \%)\end{array}$ & $\begin{array}{l}\text { Mixture of } \\
\text { fungicides } \\
(\mathrm{F}) \\
10(\mathbf{1 5 \%})\end{array}$ & $\begin{array}{l}\text { Mixture of } \\
\qquad+\mathrm{H} \\
7(\mathbf{1 0 . 5 \%})\end{array}$ & $\begin{array}{l}\text { Mixture of } \\
\mathrm{I}+\mathrm{F} \\
8(12 \%)\end{array}$ & $\begin{array}{l}\text { Mixture of } \\
\quad \mathrm{H}+\mathrm{F} \\
\mathbf{3}(4.5 \%)\end{array}$ & $\begin{array}{c}\begin{array}{c}\text { Mixture of } \\
\mathrm{I}+\mathrm{F}+\mathrm{H}\end{array} \\
5(7.5 \%)\end{array}$ \\
\hline $\begin{array}{l}\text { Parameters linked to } \\
\text { neurotoxicity, brain, } \\
\text { central nervous system, or } \\
\text { neuronal functions } \\
20 \text { mixtures assessed in } \\
\text { total }\end{array}$ & $\begin{array}{l}\text { 15 (75\%) } \\
\text { (Richardson, } \\
\text { Chambers et al. 2001; } \\
\text { Axelrad, Howard et } \\
\text { al. 2002; Timchalk, } \\
\text { Poet et al. 2005; } \\
\text { Flaskos, Harris et al. } \\
\text { 2007; Tuzmen, } \\
\text { Candan et al. 2007; } \\
\text { Wolansky, Gennings } \\
\text { et al. 2009; Cao, } \\
\text { Shafer et al. 2011; } \\
\text { Ojha, Yaduvanshi et } \\
\text { al. 2011; Coleman, } \\
\text { O'Neil et al. 2012; } \\
\text { Heusinkveld and } \\
\text { Westerink 2012; } \\
\text { Moser, Padilla et al. } \\
\text { 2012; Mwanza, Lyke } \\
\text { et al. 2012; Scelfo, } \\
\text { Politi et al. 2012; } \\
\text { Meijer, Hamers et al. } \\
\text { 2014; Wang, Wang et } \\
\text { al. 2014) }\end{array}$ & None & $\begin{array}{l}\qquad \mathbf{1}(\mathbf{5 \%}) \\
\text { (Heusinkveld, } \\
\text { Molendijk et al. } \\
\text { 2013) }\end{array}$ & None & $\begin{array}{l}\text { 1(5\%) } \\
(\mathrm{Jia} \text { and Misra } \\
\text { 2007) }\end{array}$ & $\begin{array}{l}\mathbf{3}(\mathbf{1 5 \%}) \\
\text { (Thiruchelvam, Richfield } \\
\text { et al. 2000; Reeves, } \\
\text { Thiruchelvam et al. 2003; } \\
\text { Cicchetti, Lapointe et al. } \\
\text { 2005) }\end{array}$ & None \\
\hline
\end{tabular}




\begin{tabular}{|c|c|c|c|c|c|c|c|}
\hline $\begin{array}{c}\text { Hematopoietic and } \\
\text { immune parameters } \\
8 \text { mixtures assessed in } \\
\text { total }\end{array}$ & 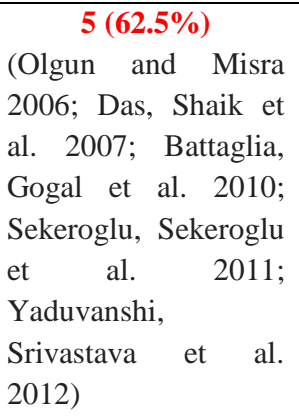 & & None & \begin{tabular}{l}
\multicolumn{2}{c}{$\mathbf{2 5 \% )}$} \\
(Pruett, Fan et \\
al. $\quad 2006$; \\
Demur, Metais \\
et al. 2013)
\end{tabular} & $\begin{array}{l}1(\mathbf{1 2 . 5 \% )}) \\
\text { (Demsia, Vlastos et } \\
\text { al. 2007) }\end{array}$ & None & None \\
\hline $\begin{array}{l}\text { Parameters of cell biology } \\
\text { (proliferation, oxidative } \\
\text { stress, DNA damage) or } \\
\text { metabolism } \\
\text { (detoxification, hepatic, } \\
\text { renal, energetic, general) } \\
20 \text { mixtures assessed in } \\
\text { total }\end{array}$ & $\begin{array}{l}\mathbf{6}(\mathbf{3 0 \%}) \\
\text { (Payne, Scholze et al. } \\
\text { 2001; Ojha and } \\
\text { Srivastava 2011; } \\
\text { Crepet, Heraud et al. } \\
\text { 2013; Takakura, } \\
\text { Sanders et al. 2013; } \\
\text { Josse, Sharanek et al. } \\
\text { 2014; Savary, Josse } \\
\text { et al. 2014) }\end{array}$ & \begin{tabular}{l}
\multicolumn{2}{c}{$\mathbf{2 ( 1 0 \% )}$} \\
(Crepet, Heraud \\
et al. 2013; \\
Takakura, \\
Sanders et al. \\
2013)
\end{tabular} & & 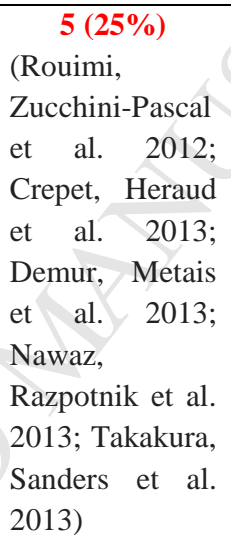 & $\begin{array}{l}\text { 4 (20\%) } \\
\text { (Rana and } \\
\text { Shivanandappa } \\
\text { 2010; Dikic, } \\
\text { Landeka et al. 2012; } \\
\text { Crepet, Heraud et } \\
\text { al. 2013; Takakura, } \\
\text { Sanders et al. 2013) }\end{array}$ & None & $\begin{array}{l}\mathbf{3}(\mathbf{1 5 \% )} \\
\text { (Astiz, de } \\
\text { Alaniz et al. } \\
\text { 2009; Crepet, } \\
\text { Heraud et al. } \\
\text { 2013; Takakura, } \\
\text { Sanders et al. } \\
\text { 2013) }\end{array}$ \\
\hline $\begin{array}{l}\text { Parameters linked to } \\
\text { reproduction and/or } \\
\text { hormonal regulation } \\
19 \text { mixtures assessed in } \\
\text { total }\end{array}$ & $\begin{array}{l}\mathbf{5}(\mathbf{2 6 . 5 \%}) \\
\text { (Mumtaz, Tully et al. } \\
\text { 2002; Greenlee, Ellis } \\
\text { et al. 2004; Valeron, } \\
\text { Pestano et al. 2009; } \\
\text { Perobelli, Martinez et } \\
\text { al. 2010; Wang, } \\
\text { Kamijima et al. 2012) }\end{array}$ & $\begin{array}{l}1 \mathbf{1}(\mathbf{5 \% )} \\
\text { (Greenlee, Ellis } \\
\text { et al. 2004) }\end{array}$ & $\begin{array}{l}9(\mathbf{4 7 . 5 \% )} \\
\text { (Greenlee, Ellis et } \\
\text { al. 2004; Blystone, } \\
\text { Lambright et al. } \\
\text { 2009; Kjaerstad, } \\
\text { Taxvig et al. 2010; } \\
\text { Ohlsson, } \\
\text { Cedergreen et al. } \\
\text { 2010; Hass, Boberg } \\
\text { et al. 2012; Ermler, } \\
\text { Scholze et al. 2013; } \\
\text { Overgaard, Holst et } \\
\text { al. 2013; Prutner, } \\
\text { Nicken et al. 2013; }\end{array}$ & None & $\begin{array}{l}\mathbf{2}(\mathbf{1 0 . 5 \%}) \\
\text { (Prutner, Nicken et } \\
\text { al. 2013; Christen, } \\
\text { Crettaz et al. 2014) }\end{array}$ & None & \begin{tabular}{l}
\multicolumn{2}{c}{$\mathbf{2 ( 1 0 . 5 \% )}$} \\
(Orton, Rosivatz \\
et al. 2012; \\
Kjeldsen, \\
Ghisari et al. \\
$2013)$
\end{tabular} \\
\hline
\end{tabular}




\begin{tabular}{|l|l|l|l|l|l|l|}
\hline & & $\begin{array}{l}\text { Christen, Crettaz et } \\
\text { al. 2014) }\end{array}$ & & & \\
\hline
\end{tabular}


Table 3. Observed effects of different types of pesticide mixtures. Values in red show the number of mixtures assessed in each category. The same reference may be present at various places in the table since some authors have assessed more than one mixture or one mixture led to various effects according to the dose or chemical target.

\begin{tabular}{|c|c|c|c|c|c|c|c|c|}
\hline \multicolumn{2}{|l|}{ Reported effects } & Insecticides (I) & Herbicides (H) & Fungicides (F) & $\mathrm{I}+\mathrm{H}$ & $\mathrm{I}+\mathrm{F}$ & $\mathrm{H}+\mathrm{F}$ & $\mathrm{I}+\mathrm{F}+\mathrm{H}$ \\
\hline \multicolumn{9}{|c|}{$\begin{array}{c}\text { Interactions (24 examples) } \\
35 \%\end{array}$} \\
\hline \multirow{5}{*}{$\begin{array}{l}\text { Synergic, } \\
\text { greater- } \\
\text { than- } \\
\text { additive } \\
\text { effects or } \\
\text { supra } \\
\text { additive } \\
17 \text { examples }\end{array}$} & $\begin{array}{c}\text { Animal } \\
\text { model } \\
\text { studies } \\
8 \text { examples }\end{array}$ & $\begin{array}{l}\text { (Richardson, Chambers et al. 2001; } \\
\text { Tuzmen, Candan et al. 2007; Sekeroglu, } \\
\text { Sekeroglu et al. 2011; Moser, Padilla et } \\
\text { al. 2012; Yaduvanshi, Srivastava et al. } \\
\text { 2012) }\end{array}$ & & & $\begin{array}{l}\text { (Pruett, Fan } \\
\text { et al. 2006) }\end{array}$ & $\begin{array}{l}\text { (Demsia, } \\
\text { Vlastos et } \\
\text { al. 2007) }\end{array}$ & $\begin{array}{l}\text { (Thiruchel } \\
\text { vam, } \\
\text { Richfield } \\
\text { et al. 2000) }\end{array}$ & \\
\hline & $\begin{array}{l}\text { Human } \\
\text { primary } \\
\text { cultured } \\
\text { cells or } \\
\text { human cell } \\
\text { lines }\end{array}$ & $\begin{array}{l}\text { (Payne, Scholze et al. 2001; Das, Shaik } \\
\text { et al. 2007; Coleman, O'Neil et al. 2012; } \\
\text { Crepet, Heraud et al. 2013; Takakura, } \\
\text { Sanders et al. 2013; Savary, Josse et al. } \\
\text { 2014) }\end{array}$ & & $\begin{array}{l}\text { (Christen, Crettaz et } \\
\text { al. 2014) }\end{array}$ & & & & \\
\hline & 7 examples & & & & & & & \\
\hline & $\begin{array}{c}\text { Animal cell } \\
\text { lines }\end{array}$ & $\begin{array}{l}\text { (Axelrad, Howard et al. 2002; Kjeldsen, } \\
\text { Ghisari et al. 2013) }\end{array}$ & & & & & & \\
\hline & 2 examples & & & & & & & \\
\hline \multirow{3}{*}{$\begin{array}{c}\begin{array}{c}\text { Antagonistic } \\
\text { effect }\end{array} \\
5 \text { examples }\end{array}$} & $\begin{array}{l}\text { Animal } \\
\text { models }\end{array}$ & (Tuzmen, Candan et al. 2007) & & \multirow[t]{3}{*}{$\begin{array}{l}\text { (Blystone, Lambright } \\
\text { et al. 2009) }\end{array}$} & & & \multirow{3}{*}{$\begin{array}{l}\text { (Reeves, } \\
\text { Thiruchelv } \\
\text { am et al. } \\
\text { 2003) }\end{array}$} & \\
\hline & & & & & & & & \\
\hline & $\begin{array}{l}\text { Human } \\
\text { primary }\end{array}$ & $\begin{array}{l}\text { (Josse, Sharanek et al. 2014; Savary, } \\
\text { Josse et al. 2014) }\end{array}$ & & & & & & \\
\hline
\end{tabular}




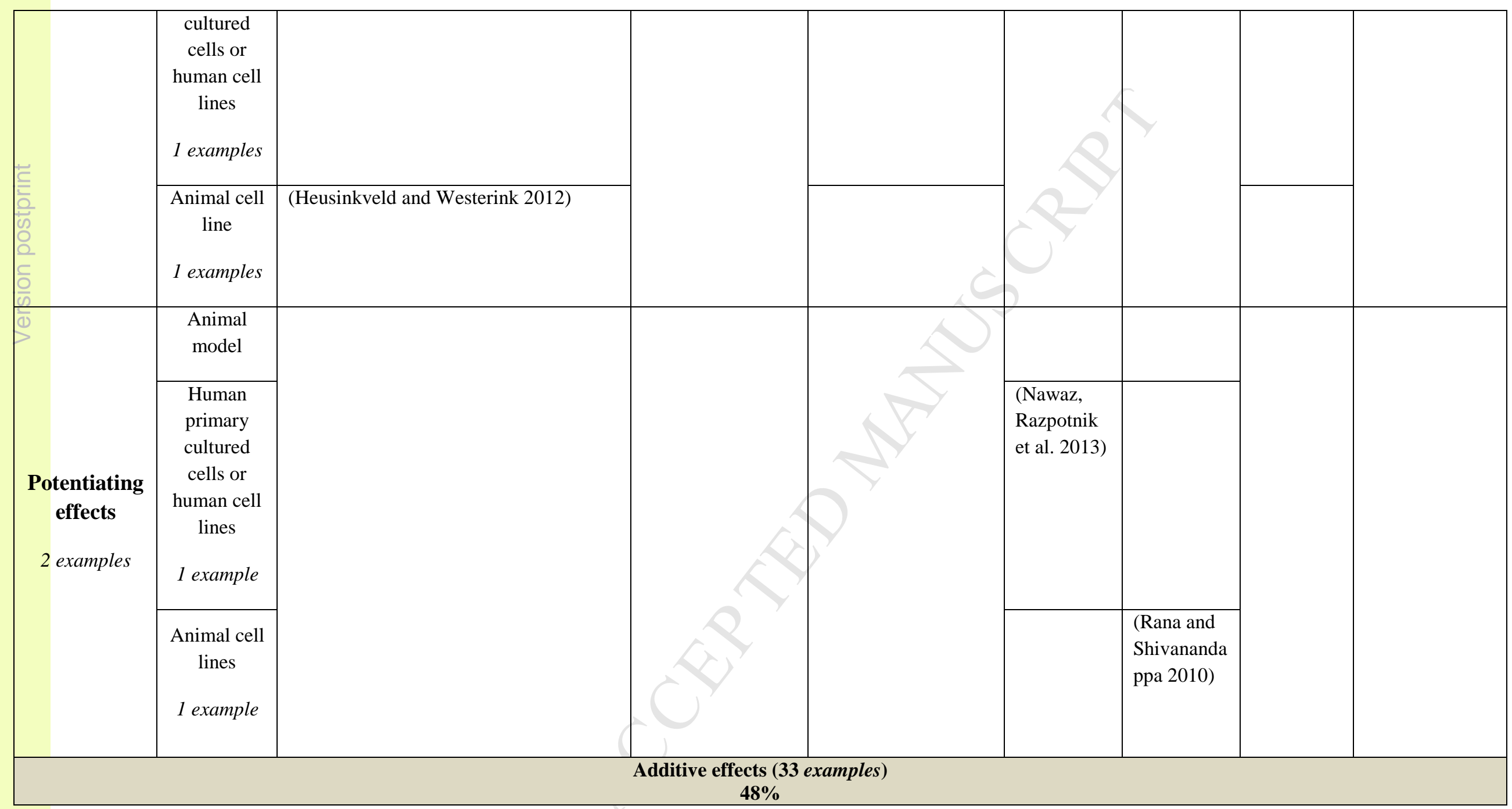




\begin{tabular}{|c|c|c|c|c|c|c|c|}
\hline$\subseteq$ & $\begin{array}{c}\text { Animal } \\
\text { models } \\
12 \\
\text { examples }\end{array}$ & $\begin{array}{l}\text { (Richardson, Chambers et al. 2001; } \\
\text { Timchalk, Poet et al. 2005; Wolansky, } \\
\text { Gennings et al. 2009; Perobelli, } \\
\text { Martinez et al. 2010; Moser, Padilla et } \\
\text { al. 2012; Mwanza, Lyke et al. 2012; } \\
\text { Wang, Kamijima et al. 2012; Wang, } \\
\text { Wang et al. 2014) }\end{array}$ & $\begin{array}{l}\text { (Hass, Boberg et al. } \\
\text { 2012) }\end{array}$ & $\begin{array}{l}\text { (Pruett, Fan } \\
\text { et al. 2006) }\end{array}$ & $\begin{array}{l}\text { (Dikic, } \\
\text { Landeka et } \\
\text { al. 2012) }\end{array}$ & & $\begin{array}{l}\text { (Astiz, de } \\
\text { Alaniz et al. } \\
\text { 2009) }\end{array}$ \\
\hline is & $\begin{array}{l}\text { Human } \\
\text { primary } \\
\text { cultured } \\
\text { cells or } \\
\text { human } \\
\text { cell lines } \\
11 \\
11 \\
\text { examples }\end{array}$ & $\begin{array}{l}\text { (Valeron, Pestano et al. 2009; Crepet, } \\
\text { Heraud et al. 2013; Josse, Sharanek et al. } \\
\text { 2014; Savary, Josse et al. 2014); }\end{array}$ & $\begin{array}{l}\text { (Kjaerstad, Taxvig et } \\
\text { al. 2010; Ohlsson, } \\
\text { Cedergreen et al. } \\
\text { 2010; Prutner, } \\
\text { Nicken et al. 2013; } \\
\text { Christen, Crettaz et } \\
\text { al. 2014) }\end{array}$ & & $\begin{array}{l}\text { (Jia and } \\
\text { Misra } \\
2007 ; \\
\text { Takakura, } \\
\text { Sanders et } \\
\text { al. 2013)) }\end{array}$ & & $\begin{array}{l}\text { (Orton, } \\
\text { Rosivatz et al. } \\
\text { 2012) }\end{array}$ \\
\hline & $\begin{array}{c}\text { Animal } \\
\text { cell lines } \\
\\
10 \\
\text { examples }\end{array}$ & $\begin{array}{l}\text { (Olgun and Misra 2006; Battaglia, Gogal } \\
\text { et al. 2010; Cao, Shafer et al. 2011; } \\
\text { Heusinkveld and Westerink 2012; } \\
\text { Scelfo, Politi et al. 2012; Meijer, } \\
\text { Hamers et al. 2014) }\end{array}$ & $\begin{array}{l}\text { (Ermler, Scholze et } \\
\text { al. 2013; } \\
\text { Heusinkveld, } \\
\text { Molendijk et al. } \\
\text { 2013) }\end{array}$ & & & & $\begin{array}{l}\text { (Orton, } \\
\text { Rosivatz et al. } \\
\text { 2012; Kjeldsen, } \\
\text { Ghisari et al. } \\
\text { 2013) }\end{array}$ \\
\hline \multicolumn{8}{|c|}{$\begin{array}{l}\text { No interaction and no additive effects (12 studies) } \\
17 \%\end{array}$} \\
\hline & $\begin{array}{c}\text { Animal } \\
\text { models } \\
6 \\
6 \\
\text { examples }\end{array}$ & $\begin{array}{l}\text { (Perobelli, Martinez et al. 2010; Ojha, } \\
\text { Yaduvanshi et al. 2011) }\end{array}$ & $\begin{array}{l}\text { (Overgaard, Holst et } \\
\text { al. 2013) }\end{array}$ & $\begin{array}{l}\text { (Rouimi, } \\
\text { Zucchini- } \\
\text { Pascal et al. } \\
\text { 2012; } \\
\text { Demur, } \\
\text { Metais et } \\
\text { al. 2013) }\end{array}$ & & $\begin{array}{l}\text { (Cicchetti, } \\
\text { Lapointe et } \\
\text { al. 2005) }\end{array}$ & \\
\hline
\end{tabular}




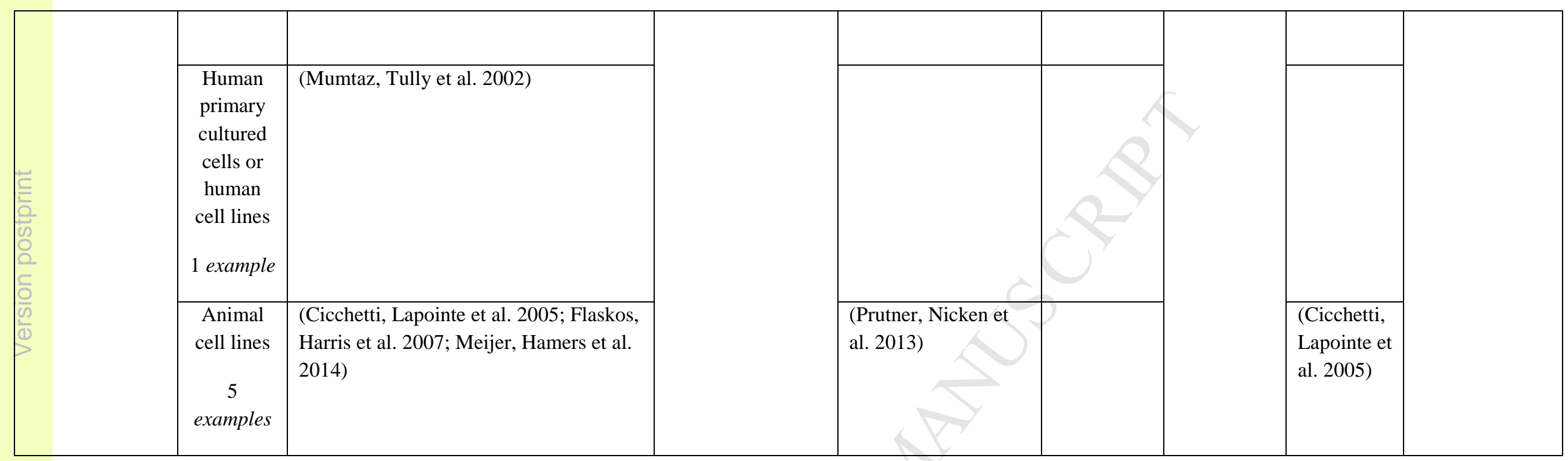


Table 4. Chemical families of pesticides involved in the various observed interactions. $\mathrm{OP}=$ organophosphorous; $\mathrm{OC}=$ organochloride PYR = pyrethrinoid; $\mathrm{AZ}=$ azole; IMI = imidazole , BenzIMI = benzimidazole TRIA = triazine $;$ TriAz $=$ triazole $; \mathrm{NEO}=$ neonicotinoide $; \mathrm{A}-\mathrm{PYR}=$ anilopyridine $;$ Dicarbo $=$ dicarboximide CARB = carbamate;

DTCARB = dithiocarbamate; $\mathrm{Bi}-\mathrm{Pyr}=$ bipyridilium; phosphono $=$ aminoacid phosphonoglycine, $\mathrm{UC}=$ unclassified.

\begin{tabular}{|c|c|c|c|c|c|c|c|c|c|c|c|c|}
\hline \multirow[b]{2}{*}{ Test system } & \multicolumn{3}{|c|}{ Neurotoxicity } & \multicolumn{3}{|c|}{ Immunity and hematopoiesis } & \multicolumn{3}{|c|}{$\begin{array}{c}\text { Metabolism, cytotoxicity, } \\
\text { apoptosis, proliferation, and } \\
\text { oxidative stress }\end{array}$} & \multicolumn{3}{|c|}{ Reproduction or hormones } \\
\hline & $\begin{array}{r}\text { Animal } \\
\text { model }\end{array}$ & $\begin{array}{c}\text { Cultured } \\
\text { human } \\
\text { cells }\end{array}$ & $\begin{array}{c}\text { Cultured } \\
\text { animal } \\
\text { cells }\end{array}$ & $\begin{array}{r}\text { Animal } \\
\text { model }\end{array}$ & $\begin{array}{l}\text { Cultured } \\
\text { human cells }\end{array}$ & $\begin{array}{l}\text { Culture } \\
\mathrm{d} \\
\text { anima } \\
\text { cells }\end{array}$ & $\begin{array}{r}\text { Animal } \\
\text { model }\end{array}$ & $\begin{array}{l}\text { Cultured } \\
\text { human } \\
\text { cells }\end{array}$ & $\begin{array}{c}\text { Cultured } \\
\text { animal } \\
\text { cells }\end{array}$ & $\begin{array}{r}\text { Animal } \\
\text { model }\end{array}$ & $\begin{array}{l}\text { Cultured } \\
\text { human cells }\end{array}$ & $\begin{array}{c}\text { Cultured } \\
\text { animal } \\
\text { cells }\end{array}$ \\
\hline $\begin{array}{c}\text { Synergy, } \\
\text { greater- } \\
\text { than- } \\
\text { additive } \\
\text { effect or } \\
\text { supra- } \\
\text { additive }\end{array}$ & $\begin{array}{c}\text { - OPoxon+ } \\
\text { OP oxon } \\
\text { (Richardson, } \\
\text { Chambers et } \\
\text { al. 2001) } \\
\text { - PYR+OP } \\
\text { (Tuzmen, } \\
\text { Candan et } \\
\text { al. 2007) } \\
\text { - } 7 \text { CARB } \\
\text { ((Moser, } \\
\text { Padilla et al. } \\
\text { 2012) } \\
\text { - pyridine } \\
\text { + } \\
\text { CARB }\end{array}$ & $\begin{array}{l}\text { - } 2 \text { A- } \\
\text { PYR+1 } \\
\text { phenyl } \\
\text { pyrrole } \\
\text { (Coleman } \\
\text { O'Neil et } \\
\text { al. 2012) }\end{array}$ & $\begin{array}{l}\text { - OP+ } \\
\text { Pyrethrum } \\
\text { (Axelrad, } \\
\text { Howard et al. } \\
\text { 2002) }\end{array}$ & $\begin{array}{l}\text { - TRIA + } \\
\text { OC } \\
\text { (Pruett, Fan } \\
\text { et al. 2006) } \\
-2 \text { OP+2 } \\
\text { OC } \\
\text { (Yaduvansh } \\
\text { i, Srivastava } \\
\text { et al. 2012) } \\
\text { - PYR+ } \\
\text { NEO } \\
\text { (Sekeroglu, } \\
\text { Sekeroglu et } \\
\text { al. 2011) } \\
\text { - } 2 \text { NEO+1 } \\
\text { phenyla }\end{array}$ & $\begin{array}{l}\text { - OP +CARB } \\
\text { - OP+OC } \\
\text { - OC+CARB } \\
\text { (Das, Shaik et } \\
\text { al. 2007) } \\
\text { - } 2 \text { NEO+1 } \\
\text { phenylamid } \\
\text { e (Demsia, } \\
\text { Vlastos et al. } \\
\text { 2007) } \\
\text { - }\end{array}$ & $Y$ & & 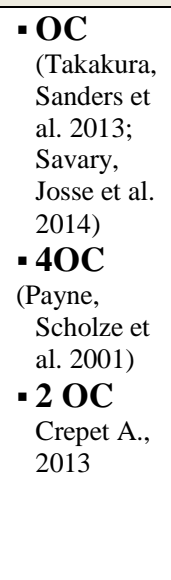 & & & $\begin{array}{l}-\mathbf{A Z + A Z} \\
\text { And } \\
\mathbf{A Z + D i C a r b} \\
\text { o (Christen, } \\
\text { Crettaz et al. } \\
\text { 2014) }\end{array}$ & $\begin{array}{l}\text { - OP+PYR } \\
\text { +2TriAZ } \\
\text { (Kjeldsen } \\
\text { LS 2013) }\end{array}$ \\
\hline
\end{tabular}




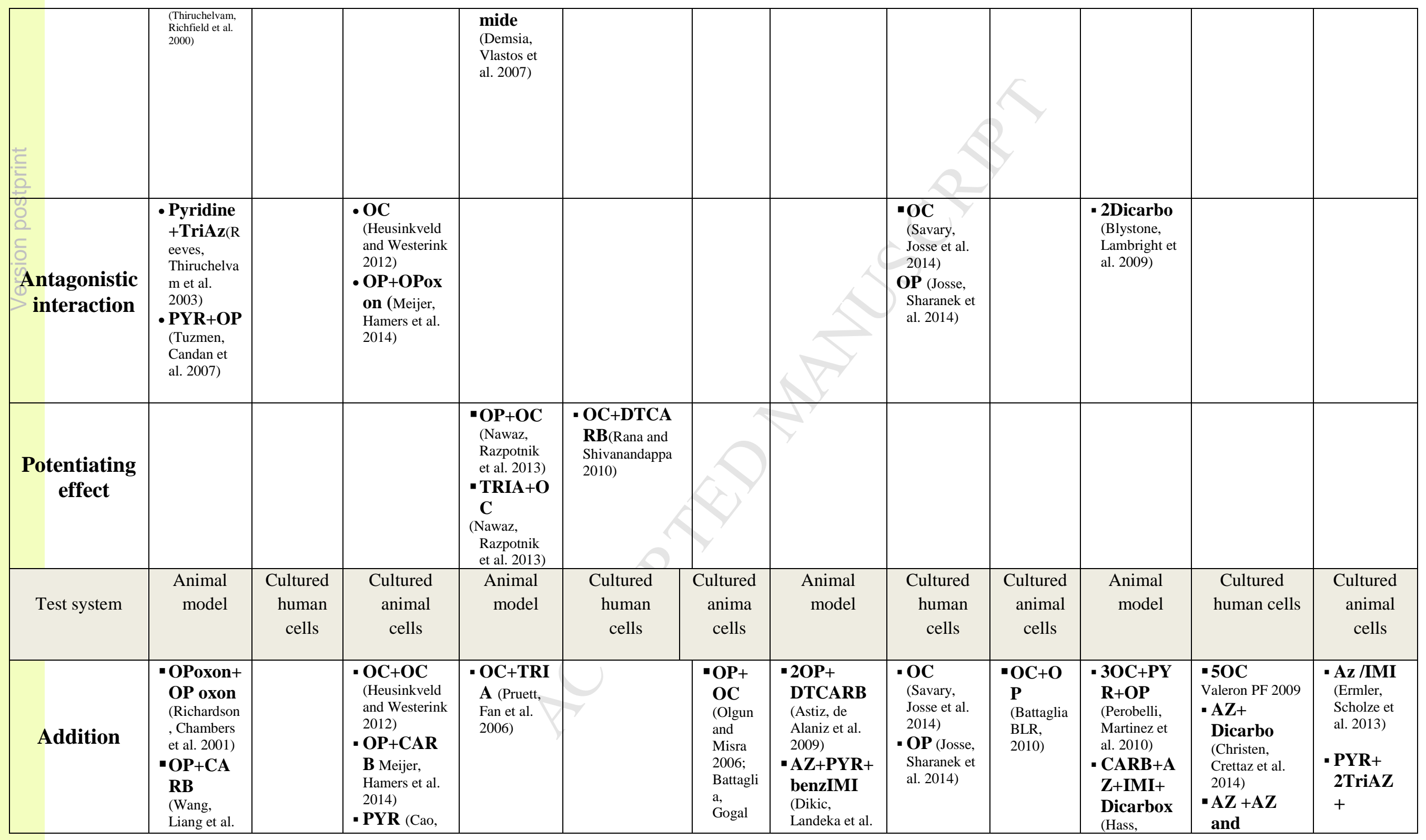




\begin{tabular}{|c|c|c|c|c|c|c|c|c|c|c|c|c|}
\hline 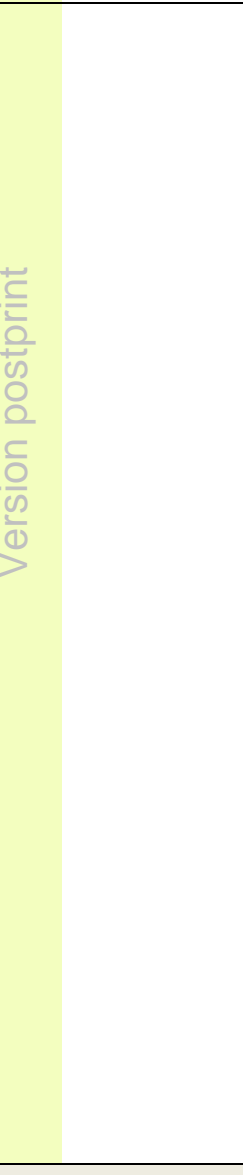 & $\begin{array}{l}\text { 2013; } \\
\text { - PYR } \\
\text { Wolansky, } \\
\text { Gennings et } \\
\text { al. 2009 } \\
\text { - OP } \\
\text { (Timchalk, } \\
\text { Poet et al. } \\
\text { 2005) } \\
\text { - } 7 \text { or 2 } \\
\text { CARB } \\
\text { (Moser, } \\
\text { Padilla et al. } \\
\text { 2012; } \\
\text { Mwanza, } \\
\text { Lyke et al. } \\
\text { 2012) } \\
\text { - OP+PYR } \\
\text { ((Wang, } \\
\text { Kamijima et al. } \\
\text { 2012) }\end{array}$ & & $\begin{array}{l}\text { Shafer et al. } \\
\text { 2011; Scelfo, } \\
\text { Politi et al. } \\
\text { 2012) } \\
\text { - AZ } \\
\text { (Heusinkveld, } \\
\text { Molendijk et } \\
\text { al. 2013) }\end{array}$ & & & $\begin{array}{l}\text { et al. } \\
2010 \text { ) }\end{array}$ & 2012) & & $y$ & $\begin{array}{l}\text { Boberg et al. } \\
\text { 2012) } \\
\text { - OP+PYR } \\
\text { (Wang D, } \\
\text { 2012) }\end{array}$ & $\begin{array}{l}\text { Dicarbo+ } \\
\text { AZ } \\
\text { (Christen, } \\
\text { Crettaz et al. } \\
\text { 2014) } \\
\text { - TRIA+ } \\
\text { PYR+OP } \\
\text { +2AZ } \\
\text { (Kjeldsen, } \\
\text { Ghisari et al. } \\
\text { 2013) } \\
\text { - 3AZ } \\
\text { (Kjaerstad, } \\
\text { Taxvig et al. } \\
\text { 2010) } \\
\text { - A-PYR+ } \\
\text { Dicarbo } \\
\text { (Prutner, Nicken } \\
\text { et al. 2013) } \\
\text { - 2 IMI } \\
\text { +AZ(Ohlsson, } \\
\text { Cedergreen et } \\
\text { al. 2010) } \\
\text { 2 Phenyl } \\
\text { pyrrole+ } \\
\text { OP+2AZ+ } \\
\text { Phenol+ } \\
\text { Dicarbo+ } \\
\text { CARB } \\
\text { (Orton, } \\
\text { Rosivatz et al. } \\
\text { 2012) } \\
\end{array}$ & $\begin{array}{l}\text { TRIA(kje } \\
\text { ldsen LS, } \\
\text { 2013) }\end{array}$ \\
\hline Test system & $\begin{array}{r}\text { Animal } \\
\text { model }\end{array}$ & $\begin{array}{c}\text { Cultured } \\
\text { human } \\
\text { cells }\end{array}$ & $\begin{array}{c}\text { Cultured } \\
\text { animal } \\
\text { cells }\end{array}$ & $\begin{array}{r}\text { Animal } \\
\text { model }\end{array}$ & $\begin{array}{c}\text { Cultured } \\
\text { human } \\
\text { cells }\end{array}$ & $\begin{array}{c}\text { Cultured } \\
\text { anima } \\
\text { cells }\end{array}$ & $\begin{array}{l}\text { Animal } \\
\text { model }\end{array}$ & $\begin{array}{c}\text { Cultured } \\
\text { human } \\
\text { cells }\end{array}$ & $\begin{array}{c}\text { Cultured } \\
\text { animal } \\
\text { cells }\end{array}$ & $\begin{array}{l}\text { Animal } \\
\text { model }\end{array}$ & $\begin{array}{c}\text { Cultured } \\
\text { human } \\
\text { cells }\end{array}$ & $\begin{array}{c}\text { Cultured } \\
\text { animal } \\
\text { cells }\end{array}$ \\
\hline $\begin{array}{c}\text { No } \\
\text { interaction }\end{array}$ & $\begin{array}{l}\text { - CARB+ } \\
\text { Pyridine } \\
\text { (Cicchetti, } \\
\text { Lapointe et } \\
\text { al. 2005) } \\
\text { - OP (Ojha, }\end{array}$ & & $\begin{array}{l}-\mathbf{O P +} \\
\text { PYR } \\
\text { (Flaskos, } \\
\text { Harris et al. } \\
\text { 2007) } \\
\text { - CARB+ }\end{array}$ & $\begin{array}{l}\text {-OP+OC } \\
\text { +TRIA } \\
\text { (Demur, } \\
\text { Metais et al. } \\
\text { 2013) } \\
\text { - }\end{array}$ & & $\begin{array}{l}\text { - OP (Ojha } \\
\text { and } \\
\text { Srivastava } \\
2014)\end{array}$ & $\begin{array}{l}\text { - TRIA+OP } \\
\text { +OC } \\
\text { (Rouimi, } \\
\text { Zucchini- } \\
\text { Pascal et al. } \\
\text { 2012) }\end{array}$ & & & $\begin{array}{l}\text { - OP+OC+ } \\
\text { PYR } \\
\text { (Perobelli, } \\
\text { Martinez et } \\
\text { al. 2010) } \\
\text {-DTCARB } \\
\end{array}$ & $\begin{array}{l}\text { - OC } \\
\text { (Mumtaz, } \\
\text { Tully et al. } \\
\text { 2002) }\end{array}$ & $\begin{array}{l}\text { - A-PYR+ } \\
\text { TriAZ } \\
\text { (Prutner, } \\
\text { Nicken et al. } \\
\text { 2013) }\end{array}$ \\
\hline
\end{tabular}


Table 5a:Chemical families of pesticides specifically involved in each type of interaction. Mixtures in bold have been proven to induce their specific corresponding effects by mathematical modeling.

\begin{tabular}{|c|c|c|c|c|c|}
\hline & Synergy & Antagonism & Potentialization & Addition & No interaction \\
\hline $\begin{array}{l}\text { Cultured } \\
\text { human cells }\end{array}$ & $\begin{array}{c}\text { AZ+Dicarbo } \\
\text { OC+ CARB } \\
\text { A-PYR+ phenylpyrrole }\end{array}$ & & & $\begin{array}{c}\text { PYR+2TriAZ } \\
\text { A-PYR+Dicarb } \\
\text { 3IMI }\end{array}$ & \\
\hline $\begin{array}{c}\text { Cultured } \\
\text { animal cells }\end{array}$ & OP+PYR+2TriAZ+TRIA & & $O C+D T C A R B$ & $\begin{array}{c}\text { PYR+2AZ } \\
\text { OP+CARB } \\
\text { PYR }\end{array}$ & \\
\hline $\begin{array}{l}\text { In vivo } \\
\text { animal } \\
\text { models }\end{array}$ & $\begin{array}{c}\text { PYR+NEO } \\
\text { NEO+Phenylamide }\end{array}$ & TriAZ+pyridine & & $\begin{array}{c}\text { CARB+AZ+IMI+Dicarbo } \\
\text { PYR+BenzIMI } \\
\text { 2OP+DTCARB }\end{array}$ & $\begin{array}{c}\text { CARB+BI-Pyr } \\
\text { OP+OC+TRIA } \\
\text { DTCarb+AZ+Dicarbo }\end{array}$ \\
\hline
\end{tabular}




\begin{tabular}{|c|c|c|c|}
\hline Function & Insecticide & Fongicide & Herbicide \\
\hline \multicolumn{4}{|l|}{ Chemical family } \\
\hline $\begin{array}{l}\text { Organophosphorus } \\
\text { (OP) }\end{array}$ & $\begin{array}{c}\text { Azinphos } \\
\text { Chlorpyrifos } \\
\text { Diazinon } \\
\text { Dichlorvos } \\
\text { Dimethoate } \\
\text { Malathion } \\
\text { Monocrotophos } \\
\text { Parathion } \\
\text { Pirimiphos }\end{array}$ & & \\
\hline $\begin{array}{c}\text { Carbamate (CARB) } \\
\text { and Dithiocarbamate } \\
\text { (DTCARB) }\end{array}$ & $\begin{array}{l}\text { Carbaryl } \\
\text { Carbofuran } \\
\text { Flubendazole } \\
\text { Formetanate } \\
\text { Mebendazole } \\
\text { Methiocarbe } \\
\text { Methomyl } \\
\text { propoxur } \\
\end{array}$ & $\begin{array}{c}\text { Benomyl } \\
\text { Carbendazime } \\
\text { Zinebe } \\
\text { Thiram (DTCARB) } \\
\text { Manèbe (DTCARB) } \\
\text { Mancozeb (DTCARB) }\end{array}$ & Chlorpropham \\
\hline $\begin{array}{l}\text { Organochlorin } \\
\text { (OC) }\end{array}$ & $\begin{array}{c}\text { Aldrine } \\
\text { Beta-HCH Dieldrine } \\
\text { DDE } \\
\text { DDT } \\
\text { Dicofol } \\
\text { Endosulfan } \\
\text { Endrine } \\
\text { Lindane }\end{array}$ & & \\
\hline $\begin{array}{c}\text { Azole (AZ) } \\
\text { triazole (TriAZ) } \\
\text { Imidazole (IMI) } \\
\text { Benimidazole } \\
\text { (BenzIMI) }\end{array}$ & & $\begin{array}{c}\text { Bitertanol (TriAZ) } \\
\text { Cyproconazole(AZ) } \\
\text { Epoxiconazole(TriAZ) } \\
\text { Fluconazole(AZ) } \\
\text { Flusilazole(AZ) } \\
\text { Myclobutanil(AZ) } \\
\text { Propiconazole(TriAZ) } \\
\text { Tebuconazole(TriAZ) }\end{array}$ & $\begin{array}{l}\text { Thibendazole (BenzIMI) } \\
\text { Carbendazim (BenzIMI) }\end{array}$ \\
\hline
\end{tabular}




\begin{tabular}{|c|c|c|c|}
\hline & & Triadimefon(TriAZ) & \\
\hline $\begin{array}{l}\text { Pyrethrinoïd } \\
\text { (PYR) }\end{array}$ & $\begin{array}{l}\text { Beta-cyfluthrine } \\
\text { Bifenthrine } \\
\text { Cypermethrine } \\
\text { Deltamethrine } \\
\text { Esfenvalérate } \\
\text { Fenpropathrine } \\
\text { Lambda- } \\
\text { cyhalothrine } \\
\text { Permethrine } \\
\text { Resmethrine } \\
\text { S-bioallethrine } \\
\text { Téfluthrine }\end{array}$ & & \\
\hline $\begin{array}{c}\text { Anilino pyrimidine } \\
\text { (A-Pyr) }\end{array}$ & & $\begin{array}{l}\text { Cyprodinil } \\
\text { Pyrimethanil }\end{array}$ & \\
\hline $\begin{array}{l}\text { Dicarboximide } \\
\text { (Dicarbo) }\end{array}$ & & $\begin{array}{c}\text { Captan } \\
\text { dimethomorph } \\
\text { Iprodione } \\
\text { Procymidone } \\
\text { Vinclozoline } \\
\end{array}$ & \\
\hline $\begin{array}{l}\text { Imidazole } \\
\text { (IMI) }\end{array}$ & & $\begin{array}{c}\text { Benomyl } \\
\text { Imazalil } \\
\text { ketoconazole } \\
\text { Prochloraz } \\
\end{array}$ & \\
\hline $\begin{array}{c}\text { Neonicotinoïde } \\
\text { (NEO) }\end{array}$ & $\begin{array}{l}\text { Imidaclopride } \\
\text { Thiaclopride }\end{array}$ & & \\
\hline Phenyl pyrrole & & Fludioxonil & \\
\hline Triazine & & 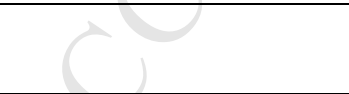 & $\begin{array}{c}\text { Atrazine } \\
\text { terbuthylazine }\end{array}$ \\
\hline $\begin{array}{l}\text { Unclassified } \\
\text { (UC) }\end{array}$ & & Fenhexamide & $\begin{array}{c}\text { Glyphosate } \\
\text { Linuron } \\
\text { Paraquat (Bi-Pyr ) } \\
\text { Metalaxil }\end{array}$ \\
\hline
\end{tabular}

Table 5b : some examples of the various chemical families of pesticides and the corresponding compounds used in this study 
Astiz, M., M. J. de Alaniz, et al. (2009). "Antioxidant defense system in rats simultaneously intoxicated with agrochemicals." Environ Toxicol Pharmacol 28(3): 465-73.

Axelrad, J. C., C. V. Howard, et al. (2002). "Interactions between pesticides and components of pesticide formulations in an in vitro neurotoxicity test." Toxicology 173(3): 259-68.

Battaglia, C. L., R. M. Gogal, Jr., et al. (2010). "Malathion, lindane, and piperonyl butoxide, individually or in combined mixtures, induce immunotoxicity via apoptosis in murine splenocytes in vitro." Int J Toxicol 29(2): 209-20.

Blystone, C. R., C. S. Lambright, et al. (2009). "Cumulative and antagonistic effects of a mixture of the antiandrogens vinclozolin and iprodione in the pubertal male rat." Toxicol Sci 111(1): 179-88.

Cao, Z., T. J. Shafer, et al. (2011). "Additivity of pyrethroid actions on sodium influx in cerebrocortical neurons in primary culture." Environ Health Perspect 119(9): 1239-46.

Christen, V., P. Crettaz, et al. (2014). "Additive and synergistic antiandrogenic activities of mixtures of azol fungicides and vinclozolin." Toxicol Appl Pharmacol 279(3): 455-466.

Christen, V., P. Crettaz, et al. (2014). "Additive and synergistic antiandrogenic activities of mixtures of azol fungicides and vinclozolin." Toxicol Appl Pharmacol 279(3): 455-66.

Cicchetti, F., N. Lapointe, et al. (2005). "Systemic exposure to paraquat and maneb models early Parkinson's disease in young adult rats." Neurobiol Dis 20(2): 360-71.

Coleman, M. D., J. D. O'Neil, et al. (2012). "A preliminary investigation into the impact of a pesticide combination on human neuronal and glial cell lines in vitro." PLoS One 7(8): e42768.

Crepet, A., F. Heraud, et al. (2013). "The PERICLES research program: an integrated approach to characterize the combined effects of mixtures of pesticide residues to which the French population is exposed." Toxicology 313(2-3): 83-93.

Das, P. P., A. P. Shaik, et al. (2007). "Genotoxicity induced by pesticide mixtures: in-vitro studies on human peripheral blood lymphocytes." Toxicol Ind Health 23(8): 449-58.

Demsia, G., D. Vlastos, et al. (2007). "Assessment of the genotoxicity of imidacloprid and metalaxyl in cultured human lymphocytes and rat bone-marrow." Mutat Res 634(1-2): 32-9.

Demur, C., B. Metais, et al. (2013). "Dietary exposure to a low dose of pesticides alone or as a mixture: the biological metabolic fingerprint and impact on hematopoiesis." Toxicology 308: 74-87.

Dikic, D., I. Landeka, et al. (2012). "Carbendazim impends hepatic necrosis when combined with imazalil or cypermethrin." Basic Clin Pharmacol Toxicol 110(5): 433-40.

Ermler, S., M. Scholze, et al. (2013). "Seven benzimidazole pesticides combined at sub-threshold levels induce micronuclei in vitro." Mutagenesis 28(4): 41726.

Flaskos, J., W. Harris, et al. (2007). "The effects of diazinon and cypermethrin on the differentiation of neuronal and glial cell lines." Toxicol Appl Pharmacol 219(2-3): 172-80. 
Greenlee, A. R., T. M. Ellis, et al. (2004). "Low-dose agrochemicals and lawn-care pesticides induce developmental toxicity in murine preimplantation embryos." Environ Health Perspect 112(6): 703-9.

Hass, U., J. Boberg, et al. (2012). "Adverse effects on sexual development in rat offspring after low dose exposure to a mixture of endocrine disrupting pesticides." Reprod Toxicol 34(2): 261-74.

Heusinkveld, H. J., J. Molendijk, et al. (2013). "Azole fungicides disturb intracellular Ca2+ in an additive manner in dopaminergic PC12 cells." Toxicol Sci 134(2): 374-81.

Heusinkveld, H. J. and R. H. Westerink (2012). "Organochlorine insecticides lindane and dieldrin and their binary mixture disturb calcium homeostasis in dopaminergic PC12 cells." Environ Sci Technol 46(3): 1842-8.

Jia, Z. and H. P. Misra (2007). "Exposure to mixtures of endosulfan and zineb induces apoptotic and necrotic cell death in SH-SY5Y neuroblastoma cells, in vitro." J Appl Toxicol 27(5): 434-46.

Josse, R., A. Sharanek, et al. (2014). "Impact of isomalathion on malathion cytotoxicity and genotoxicity in human HepaRG cells." Chem Biol Interact 209: 6876.

Kjaerstad, M. B., C. Taxvig, et al. (2010). "Mixture effects of endocrine disrupting compounds in vitro." Int J Androl 33(2): 425-33.

Kjeldsen, L. S., M. Ghisari, et al. (2013). "Currently used pesticides and their mixtures affect the function of sex hormone receptors and aromatase enzyme activity." Toxicol Appl Pharmacol 272(2): 453-64.

Meijer, M., T. Hamers, et al. (2014). "Acute disturbance of calcium homeostasis in PC12 cells as a novel mechanism of action for (sub)micromolar concentrations of organophosphate insecticides." Neurotoxicology.

Meijer, M., T. Hamers, et al. (2014). "Acute disturbance of calcium homeostasis in PC12 cells as a novel mechanism of action for (sub)micromolar concentrations of organophosphate insecticides." Neurotoxicology 43: 110-6.

Moser, V. C., S. Padilla, et al. (2012). "Impact of chemical proportions on the acute neurotoxicity of a mixture of seven carbamates in preweanling and adult rats." Toxicol Sci 129(1): 126-34.

Mumtaz, M. M., D. B. Tully, et al. (2002). "Gene induction studies and toxicity of chemical mixtures." Environ Health Perspect 110 Suppl 6: 947-56.

Mwanza, J. C., D. F. Lyke, et al. (2012). "Cholinesterase inhibition and depression of the photic after discharge of flash evoked potentials following acute or repeated exposures to a mixture of carbaryl and propoxur." Neurotoxicology 33(3): 332-46.

Nawaz, A., A. Razpotnik, et al. (2013). "Cellular impact of combinations of endosulfan, atrazine, and chlorpyrifos on human primary hepatocytes and HepaRG cells after short and chronic exposures." Cell Biol Toxicol 30(1): 17-29.

Ohlsson, A., N. Cedergreen, et al. (2010). "Mixture effects of imidazole fungicides on cortisol and aldosterone secretion in human adrenocortical H295R cells." Toxicology 275(1-3): 21-8.

Ojha, A. and N. Srivastava (2011). "Redox imbalance in rat tissues exposed with organophosphate pesticides and therapeutic potential of antioxidant vitamins." Ecotoxicol Environ Saf 75(1): 230-41.

Ojha, A. and N. Srivastava (2014). "In vitro studies on organophosphate pesticides induced oxidative DNA damage in rat lymphocytes." Mutat Res 761: $10-7$.

Ojha, A., S. K. Yaduvanshi, et al. (2011). "Evaluation of DNA damage and cytotoxicity induced by three commonly used organophosphate pesticides individually and in mixture, in rat tissues." Environ Toxicol 28(10): 543-52. 
Olgun, S. and H. P. Misra (2006). "Pesticides induced oxidative stress in thymocytes." Mol Cell Biochem 290(1-2): 137-44.

Orton, F., E. Rosivatz, et al. (2012). "Competitive androgen receptor antagonism as a factor determining the predictability of cumulative antiandrogenic effects of widely used pesticides." Environ Health Perspect 120(11): 1578-84.

Overgaard, A., K. Holst, et al. (2013). "The effect of perinatal exposure to ethinyl oestradiol or a mixture of endocrine disrupting pesticides on kisspeptin neurons in the rat hypothalamus." Neurotoxicology 37: 154-62.

Payne, J., M. Scholze, et al. (2001). "Mixtures of four organochlorines enhance human breast cancer cell proliferation." Environ Health Perspect 109(4): 3917.

Perobelli, J. E., M. F. Martinez, et al. (2010). "Decreased sperm motility in rats orally exposed to single or mixed pesticides." J Toxicol Environ Health A 73(1314): 991-1002.

Pruett, S. B., R. Fan, et al. (2006). "Greater than additive suppression of TLR3-induced IL-6 responses by administration of dieldrin and atrazine." $\underline{\mathrm{J}}$ Immunotoxicol 3(4): 253-62.

Prutner, W., P. Nicken, et al. (2013). "Effects of single pesticides and binary pesticide mixtures on estrone production in H295R cells." Arch Toxicol.

Rana, I. and T. Shivanandappa (2010). "Mechanism of potentiation of endosulfan cytotoxicity by thiram in Ehrlich ascites tumor cells." Toxicol In Vitro 24(1): 40-4.

Reeves, R., M. Thiruchelvam, et al. (2003). "Interactions of paraquat and triadimefon: behavioral and neurochemical effects." Neurotoxicology 24(6): 839-50.

Richardson, J. R., H. W. Chambers, et al. (2001). "Analysis of the additivity of in vitro inhibition of cholinesterase by mixtures of chlorpyrifos-oxon and azinphos-methyl-oxon." Toxicol Appl Pharmacol 172(2): 128-39.

Rouimi, P., N. Zucchini-Pascal, et al. (2012). "Impacts of low doses of pesticide mixtures on liver cell defence systems." Toxicol In Vitro 26(5): 718-26.

Savary, C. C., R. Josse, et al. (2014). "Interactions of endosulfan and methoxychlor involving CYP3A4 and CYP2B6 in human HepaRG cells." Drug Metab Dispos 42(8): 1235-40.

Scelfo, B., M. Politi, et al. (2012). "Application of multielectrode array (MEA) chips for the evaluation of mixtures neurotoxicity." Toxicology 299(2-3): 172-83.

Sekeroglu, V., Z. A. Sekeroglu, et al. (2011). "Effects of commercial formulations of deltamethrin and/or thiacloprid on thyroid hormone levels in rat serum." Toxicol Ind Health 30(1): 40-6.

Takakura, N., P. Sanders, et al. (2013). "In vitro combined cytotoxic effects of pesticide cocktails simultaneously found in the French diet." Food Chem Toxicol 52: 153-62.

Thiruchelvam, M., E. K. Richfield, et al. (2000). "The nigrostriatal dopaminergic system as a preferential target of repeated exposures to combined paraquat and maneb: implications for Parkinson's disease." J Neurosci 20(24): 9207-14.

Timchalk, C., T. S. Poet, et al. (2005). "Pharmacokinetic and pharmacodynamic interaction for a binary mixture of chlorpyrifos and diazinon in the rat." Toxicol Appl Pharmacol 205(1): 31-42.

Tuzmen, M. N., N. Candan, et al. (2007). "The evaluation of altered antioxidative defense mechanism and acetylcholinesterase activity in rat brain exposed to chlorpyrifos, deltamethrin, and their combination." Toxicol Mech Methods 17(9): 535-40.

Valeron, P. F., J. J. Pestano, et al. (2009). "Differential effects exerted on human mammary epithelial cells by environmentally relevant organochlorine pesticides either individually or in combination." Chem Biol Interact 180(3): 485-91. 
Wang, D., M. Kamijima, et al. (2012). "Evidence for diazinon-mediated inhibition of cis-permethrin metabolism and its effects on reproductive toxicity in adult male mice." Reprod Toxicol 34(4): 489-97.

Wang, P., H. P. Wang, et al. (2014). "Combined subchronic toxicity of dichlorvos with malathion or pirimicarb in mice liver and serum: a metabonomic study." Food Chem Toxicol 70: 222-30.

Wolansky, M. J., C. Gennings, et al. (2009). "Evidence for dose-additive effects of pyrethroids on motor activity in rats." Environ Health Perspect 117(10): 1563-70.

Yaduvanshi, S. K., N. Srivastava, et al. (2012). "Evaluation of micronuclei induction capacity and mutagenicity of organochlorine and organophosphate pesticides." Drug Metab Lett 6(3): 187-97. 


\begin{tabular}{|c|c|c|c|c|}
\hline \multicolumn{5}{|c|}{ Thiruchelvam M., 2000} \\
\hline C57BL/6 mice & Paraquat and Maneb & $\begin{array}{l}\cdot 5-10 \mathrm{mg} / \mathrm{kg} \\
\text { paraquat } \\
15-30 \mathrm{mg} / \mathrm{kg} \\
\text { maneb } \\
\bullet \text { IP once a week } \\
\text { for } 4 \text { weeks }\end{array}$ & $\begin{array}{l}\text { Nigrostriatal } \\
\text { dopamine } \\
\text { system }\end{array}$ & $\begin{array}{l}\text { No effect of pesticide } \\
\text { alone; effect of the } \\
\text { mixture. Sustained } \\
\text { decreases in motor } \\
\text { activity levels for } \\
\text { dopamine and } \\
\text { metabolites and } \\
\text { dopamine turnover } \\
\text { increased. Reductions } \\
\text { in tyrosine } \\
\text { hydroxylase } \\
\text { immunoreactivity }\end{array}$ \\
\hline \multicolumn{5}{|c|}{ Castillo C.G., 2002} \\
\hline $\begin{array}{l}\text { In vivo, male } \\
\text { Wistar rats }\end{array}$ & $\begin{array}{l}\text { Endosulfan and methyl } \\
\text { parathion and commercial } \\
\text { preparation of the mixture }\end{array}$ & $\begin{array}{l}(25 \mathrm{mg} / \mathrm{kg}) \mathrm{E} \\
(2 \mathrm{mg} / \mathrm{kg}) \mathrm{P} \\
\text {-SC } 10 \text { days }\end{array}$ & $\begin{array}{l}\text { Neurological } \\
\text { renal and hepatic } \\
\text { marker functions }\end{array}$ & $\begin{array}{l}\text { When given in } \\
\text { combination, the } \\
\text { commercial } \\
\text { formulation of ES and } \\
\text { MP can produce } \\
\text { behavioral alterations }\end{array}$ \\
\hline \multicolumn{5}{|c|}{ De la Rosa, P., 2003} \\
\hline $\begin{array}{l}\text { In vivo } \\
\text { female C57 } \\
\text { BL/6 mice }\end{array}$ & $\begin{array}{l}\text { 3,4-dichloro } \\
\text { propionanilide (propanil) } \\
\text { and 2,4-dichloro } \\
\text { phenoxyacetic acid (2,4- } \\
\text { D) }\end{array}$ & $\begin{array}{l}-14,50 \text { to } 200 \\
\mathrm{mg} / \mathrm{kg} \text { bw } \\
\cdot 2 \text { consecutive IP } \\
\text { - extraction bone } \\
\text { marrow at day } 1 \text {, } \\
2,7 \text { and } 14 \text { post } \\
\text { treatment }\end{array}$ & $\begin{array}{l}\text { alterations to } \\
\text { bone marrow B- } \\
\text { cell populations } \\
\text { after in vivo } \\
\text { exposure }\end{array}$ & $\begin{array}{l}\text { Exposure to the } \\
\text { mixture had greater } \\
\text { toxic effects than the } \\
\text { individual herbicides } \\
\text { on bone marrow pre- } \\
\text { B and IgM(+) B-cell } \\
\text { populations, }\end{array}$ \\
\hline \multicolumn{5}{|c|}{ Karanth s 2004} \\
\hline $\begin{array}{l}\text { In vivo rat } \\
\text { Sprague dawley }\end{array}$ & $\begin{array}{l}\text { Methyl parathion and } \\
\text { chlorpyrifos }\end{array}$ & $\begin{array}{l}\text { - Oral exposure } \\
\text { gavage. } \\
\text { - Effect of } \\
\text { concurrent an } \\
\text { sequential } \\
\text { exposure to } \\
\text { Acute exposure } \\
\text { to LD 96H of } \\
\text { CPF and MPS }\end{array}$ & $\begin{array}{l}\text { Lethality, } \\
\text { cholinergic signs } \\
\text { and biochemical } \\
\text { endpoints }\end{array}$ & $\begin{array}{l}\text { Sequence of exposure } \\
\text { to OP that elicits } \\
\text { toxicity through a } \\
\text { common mechanism } \\
\text { of action can } \\
\text { markedly influence } \\
\text { the cumulative action } \\
\text { at the targeted site } \\
\text { (AChE and } \\
\text { consequent functional } \\
\text { toxicity). No } \\
\text { information on the } \\
\text { nature of interaction }\end{array}$ \\
\hline \multicolumn{5}{|c|}{ Cory-Slechta D.A., 2005} \\
\hline $\begin{array}{l}\text { In vivo, mice } \\
\text { C57/B16 }\end{array}$ & $\begin{array}{l}\text { Paraquat (PQ) and Maneb } \\
\text { (MB) } \\
\mathrm{H}+\mathrm{F} \\
\mathrm{OP}+\mathrm{CARB}\end{array}$ & $\begin{array}{l}\text { - Subcutaneous } \\
\text { administration } \\
\text { - From postnatal } \\
\text { days } 5-19,0.3 \\
\mathrm{mg} / \mathrm{kg} \mathrm{PQ}, 1 \\
\mathrm{mg} / \mathrm{kg} \mathrm{MB} \\
\text { - From gestational } \\
\text { day } 10-17,1 \\
\mathrm{mg} / \mathrm{kg} \mathrm{MB}, \text { and } \\
\text { at weeks } 7-8,5 \\
\mathrm{mg} / \mathrm{kg} \mathrm{PQ} \text { or } 15 \\
\mathrm{mg} / \mathrm{kg} \mathrm{MB} \text { for } 8 \\
\text { days }\end{array}$ & $\begin{array}{l}\text { Dopamine } \\
\text { systems of the } \\
\text { nigrostriatal } \\
\text { pathway }\end{array}$ & $\begin{array}{l}\text { Cumulative } \\
\text { neurotoxicity; effects } \\
\text { of PQ and MB were } \\
\text { greater those of either } \\
\text { pesticide alone } \\
\text { (postnatal model) }\end{array}$ \\
\hline \multicolumn{5}{|l|}{ Jiaz Z., 2007} \\
\hline Invitro, Briand, & Endosulfan, zinebt $\mathrm{Pa}$ & $.100 \mu \mathrm{M}(\mathrm{LC} 25)$ & IODH & Toxicity of mixture \\
\hline
\end{tabular}




\begin{tabular}{|c|c|c|c|c|}
\hline $\begin{array}{l}\text { neuroblastoma } \\
\text { SH-SY5Y cells }\end{array}$ & & $16 \mathrm{~h}$ & necrosis & $\begin{array}{l}\text { greater than that of } \\
\text { individual compounds }\end{array}$ \\
\hline \multicolumn{5}{|c|}{ Metzdorff SB 2007} \\
\hline $\begin{array}{l}\text { In vivo Female } \\
\text { wistar rats }\end{array}$ & $\begin{array}{l}\text { Vinclozolin, } \\
\text { procymidone flutamide } \\
\text { Flutamide is not a } \\
\text { pesticide }\end{array}$ & $\begin{array}{l}\text { Oral exposure } \\
\text { from GD } 7 \text { to PND } \\
16 \\
\text { mixture ratio of } \\
\text { vinclozolin, } \\
\text { flutamide, and } \\
\text { procymidone was } \\
0.62: 0.02: 0.36 \text {, } \\
\text { and the master } \\
\text { mixture contained } \\
22.026 \mathrm{mg} \\
\text { vinclozolin, } 696.6 \\
\text { mg flutamide, and } \\
12.675 \mathrm{mg} \\
\text { procymidon in } 600 \\
\text { ml corn oil. }\end{array}$ & $\begin{array}{l}\text { Reproductive } \\
\text { organ weight, } \\
\text { androgen } \\
\text { regulated gene } \\
\text { expression in } \\
\text { prostates from } \\
\text { male rat pups }\end{array}$ & Additive effects \\
\hline \multicolumn{5}{|c|}{ Gomez J., 2009} \\
\hline $\begin{array}{l}\text { In vivo, } \\
\text { male and female } \\
\text { TO strain mice }\end{array}$ & $\begin{array}{l}\text { Pesticide formulations } \\
\text { of OP: Salut, Selecron, } \\
\text { Dursban, Acetllic, } \\
\text { Hosthation, Nogos }\end{array}$ & $\begin{array}{l}\cdot 3 \%, 10 \% \text { LD50 } \\
\text { - Gavage } \\
\text { - } 7 \text { weeks before } \\
\text { premating and } \\
\text { preconception }\end{array}$ & $\begin{array}{l}\text { Gestational and } \\
\text { litter outcomes }\end{array}$ & Positive Interaction \\
\hline \multicolumn{5}{|c|}{ Yavuz 0,2010} \\
\hline $\begin{array}{l}\text { In vivo: } \\
\text { male Wistar } \\
\text { Rats }\end{array}$ & $\begin{array}{l}\text { Tetramethrin a- } \\
\text { Cypermethrin, } \\
\text { Deltamethrin, } \\
\text { Cypermethrin, piperonyl } \\
\text { butoxide (BPO)(inhibition } \\
\text { Various mixture }\end{array}$ & $\begin{array}{l}\bullet 1 / 5 \text { LD50 } \\
\text { Dermal exposure } \\
\bullet 14 \text { days }\end{array}$ & $\begin{array}{l}\text { hematologic and } \\
\text { biochemical } \\
\text { parameters }\end{array}$ & $\begin{array}{l}\text { their findings showed } \\
\text { that although } \\
\text { pyrethroids are } \\
\text { considered to be of } \\
\text { low acute toxicity, } \\
\text { they become more } \\
\text { toxic when combined } \\
\text { with piperonyl } \\
\text { butoxide or } \\
\text { tetramethrin in certain } \\
\text { doses }\end{array}$ \\
\hline \multicolumn{5}{|c|}{ Sharma H 2010.} \\
\hline $\begin{array}{l}\text { immortalized rat } \\
\text { N27 DA } \\
\text { neurons }\end{array}$ & dieldrin and lindane & $\begin{array}{l}5 \text { to } 25 \mu \mathrm{M} \\
48 \mathrm{H}\end{array}$ & $\begin{array}{l}\text { Cell viability, } \\
\text { mitochondria } \\
\text { membrane } \\
\text { potential, } \\
\text { caspase ROS }\end{array}$ & $\begin{array}{l}\text { dieldrin and lindane } \\
\text { work cooperatively to } \\
\text { induce neurotoxicity. } \\
\text { Dieldrin and lindane } \\
\text { interacts via different } \\
\text { manner: they interact } \\
\text { on neuronal gaba } \\
\text { receptor (increase ca } \\
\text { and OS) L and D } \\
\text { interact on } \\
\text { mitochondrial } \\
\text { membrane potential }\end{array}$ \\
\hline \multicolumn{5}{|c|}{ Chatterjee S., 2011} \\
\hline $\begin{array}{l}\text { Bone marrow } \\
\text { explants In vitro } \\
\text { from albino } \\
\text { Swiss mice }\end{array}$ & $\begin{array}{l}\text { Alphamethrin, } \\
\text { cypermethrine, } \\
\text { profenofos, } \\
\text { chloropyrofos }\end{array}$ & $\begin{array}{l}\bullet 10 \%(\mathrm{w} / \mathrm{v}) \text { alpha, } \\
9 \% \text { Cyper, } 40 \% \\
\text { Profenofos, } 50 \% \\
\text { Chloropyrofos } \\
25 \text { days } \\
\end{array}$ & $\begin{array}{l}\text { CFU, colony } \\
\text { forming assay, } \\
\text { cell cycle, } \\
\text { apoptosis }\end{array}$ & $\begin{array}{l}\text { Toxicity of the } \\
\text { mixture }\end{array}$ \\
\hline
\end{tabular}




\begin{tabular}{|c|c|c|c|c|}
\hline \multicolumn{5}{|l|}{ Aubé M. 2011} \\
\hline $\begin{array}{l}\text { In vitro } \\
\text { Mammary } \\
\text { cancerous cell } \\
\text { line CAMA-1, } \\
\text { MCF-7, T47D, } \\
\text { MDAMB231 } \\
\text { and normal } \\
\text { mammary cells } \\
\text { CV-1 }\end{array}$ & $\begin{array}{l}\text { OC } \\
\text { PC,B p,p0-DDE, a-HCH, } \\
\text { p,p0-DDT, toxaphene, } \\
\text { Aldrin, Dieldrin, Tetra- } \\
\text { chlorobenzene, b-HCH, } \\
\text { p,p0-DDD, } \\
\text { Hexachlorobenzene, } \\
\text { Pentachlorobenzene, g- } \\
\text { HCH, Mirex }\end{array}$ & $\begin{array}{l}- \text { dilutions } 100 \times 10^{3} \\
\text { and } 50 \times 10^{3}\end{array}$ & $\begin{array}{l}\text { Proliferative } \\
\text { activity }\end{array}$ & $\begin{array}{l}\text { Differential effects } \\
\text { according to the cell } \\
\text { line and the estrogenic } \\
\text { or anti-androgenic } \\
\text { activity of the } \\
\text { compounds }\end{array}$ \\
\hline \multicolumn{5}{|l|}{ Yang J., 2012} \\
\hline $\begin{array}{l}\text { In vivo, male } \\
\text { Wistar rats }\end{array}$ & $\begin{array}{l}\text { Dichlorvos, acephate, } \\
\text { dimethoate, and phorate }\end{array}$ & $\begin{array}{l}\cdot 1 \mathrm{x}, 3 \mathrm{x}, \text { and } 9 \mathrm{x} \\
\text { NOAEL } \\
\text { - Drinking water } \\
24 \text { weeks }\end{array}$ & $\begin{array}{l}\text { Oxidative } \\
\text { damage in liver }\end{array}$ & $\begin{array}{l}\text { The responses to the } \\
\text { mixture did not } \\
\text { constitute the sum of } \\
\text { the responses } \\
\text { produced by each } \\
\text { pesticide }\end{array}$ \\
\hline \multicolumn{5}{|c|}{ Dubey N., 2013} \\
\hline $\begin{array}{l}\text { In vivo, male } \\
\text { and female adult } \\
\text { Wistar rats }\end{array}$ & Deltamethrin, fluoride & $\begin{array}{l}\cdot 1 / 100 \text { LD50 and } \\
20 \text { ppm } \\
\cdot \text { Daily gavage } \\
28 \text { days }\end{array}$ & $\begin{array}{l}\text { Oxidative stress } \\
\text { in liver, } \\
\text { biochemical } \\
\text { parameters }\end{array}$ & Positive interaction \\
\hline \multicolumn{5}{|c|}{ Wang H.P., 2013} \\
\hline $\begin{array}{l}\text { In vivo, male } \\
\text { Wistar rats }\end{array}$ & Dichlorvos, deltamethrin & $\begin{array}{l}\cdot 1 / 20,1 / 50, \text { and } \\
1 / 125 \text { LD50 } \\
\cdot \text { Daily gavage } \\
\cdot 90 \text { days }\end{array}$ & $\begin{array}{l}\text { Metabonomic } \\
\text { analysis of the } \\
\text { serum and urine }\end{array}$ & $\begin{array}{l}\text { Changes in serum } \\
\text { TMAO, alanine, } \\
\text { choline, and acetone } \\
\text { in this treatment } \\
\text { group } \\
\text { were higher than in } \\
\text { rats treated with either } \\
\text { dichlorvos or } \\
\text { deltamethrin } \\
\end{array}$ \\
\hline \multicolumn{5}{|l|}{ Du L., 2013} \\
\hline $\begin{array}{l}\text { In vivo, } \\
\text { male Wistar rats }\end{array}$ & $\begin{array}{l}\text { Dichlorvos, acéphate } \\
\text { dimethoate, phorate }\end{array}$ & $\begin{array}{l}\cdot 1 \mathrm{x}, 3 \mathrm{x}, \text { and } 9 \mathrm{x} \\
\text { NOAEL } \\
\text { - In drinking } \\
\text { water, the } \\
\text { amount of OP } \\
\text { pesticides was } \\
\text { adjusted twice a } \\
\text { week for the first } \\
8 \text { weeks and then } \\
\text { once a week until } \\
\text { the end of the } \\
\text { experiment } \\
.24 \text { weeks }\end{array}$ & $\begin{array}{l}\text { Metabonomic } \\
\text { profiles of rat } \\
\text { urine }\end{array}$ & Joint toxic action \\
\hline \multicolumn{5}{|l|}{ Pant N., 2013} \\
\hline $\begin{array}{l}\text { In vitro, human } \\
\text { semen }\end{array}$ & $\begin{array}{l}\square \text { and } \square- \\
\text { hexachlorocyclohexane } \\
\text { (HCH), DDE, DDD, } \\
\text { plomb, cadmium }\end{array}$ & $\begin{array}{l}\cdot \square-\mathrm{HCH}(76.94 \\
\mu \mathrm{g} / \mathrm{L}), \square-\mathrm{HCH} \\
(39.04 \mu \mathrm{g} / \mathrm{L}), \mathrm{pp}- \\
\mathrm{DDE}(53.89 \\
\mu \mathrm{g} / \mathrm{L}), \mathrm{pp}-\mathrm{DDD} \\
(57.49 \mu \mathrm{g} / \mathrm{L}), \mathrm{Pb} \\
\text { acetate }(33.2 \\
\mu \mathrm{g} / \mathrm{L}), \mathrm{Cadmium} \\
\mathrm{Cl}(35.6 \mu \mathrm{g} / \mathrm{L}) \\
.30 \mathrm{~min} \text { at } 96 \mathrm{~h} \\
\end{array}$ & $\begin{array}{l}\text { Sperm viability } \\
\text { and motility }\end{array}$ & Positive interaction \\
\hline 113 & & & & \\
\hline
\end{tabular}




\begin{tabular}{|c|c|c|c|c|}
\hline $\begin{array}{l}\text { In vivo, male } \\
\text { Sprague-Dawley } \\
\text { rats }\end{array}$ & $\begin{array}{l}\text { Dichlorvos/ dimethoate } \\
\text { /malathion }\end{array}$ & $\begin{array}{l}\text { - } 1 / 5,1 / 10,1 / 20 \\
\text { LD50 } \\
\text { - Daily by oral } \\
\text { gavage from the } \\
15 \text { th to the } 28 \text { th } \\
\text { day of lactation }\end{array}$ & $\begin{array}{l}\text { Uterus } \\
\text { pathology, } \\
\text { neonatal } \\
\text { development, } \\
\text { reproductive } \\
\text { function in } \\
\text { offspring }\end{array}$ & $\begin{array}{l}\text { Mixture is more } \\
\text { potent than pesticide } \\
\text { alone }\end{array}$ \\
\hline \multicolumn{5}{|c|}{ Taxvig C., 2013} \\
\hline $\begin{array}{l}\text { In vitro, H295R } \\
\text { cells; in vivo, } \\
\text { pregnant rats }\end{array}$ & $\begin{array}{l}\text { Mix } 1 \text { bitertanol } \\
\text { propiconazole } \\
\text { cypermethrine and } \\
\text { Mix } 2 \text { bitertanol } \\
\text { propiconazole } \\
\text { cypermethrine malathion } \\
\text { and terbuthylazine }\end{array}$ & $\begin{array}{l}\text { Oral exposure, } \\
\text { gavage from GD7 } \\
\text { GD21 } \\
3 \text { to } 50 \mathrm{mg} / \mathrm{kg} \\
\text { In vitro } 1.6 \text { to } 100 \\
\mu \mathrm{M}\end{array}$ & $\begin{array}{l}\text { Hormone level } \\
\text { steroidogenesis }\end{array}$ & $\begin{array}{l}\text { Pesticide alone and } \\
\text { mixture affect } \\
\text { steroidogenesis }\end{array}$ \\
\hline \multicolumn{5}{|c|}{ Mishra V, 2013} \\
\hline $\begin{array}{l}\text { In vivo: } \\
\text { male albino } \\
\text { Wistar Rats }\end{array}$ & $\begin{array}{l}\text { Monocrotophos, } \\
\text { quinalphos, }\end{array}$ & $\begin{array}{l}\text { - } 0.25 \text { LD50 each } \\
\text { single pesticide, } \\
1 / 8^{\mathrm{e}} \text { LD50of each } \\
\text { pesticide in the } \\
\text { mixture } \\
\text { - gavage } \\
\text { - } 2 \text { consecutive } \\
\text { days }\end{array}$ & $\begin{array}{l}\text { Redox status of } \\
\text { tissues }\end{array}$ & $\begin{array}{l}\text { No synergistic effect } \\
\text { compared to single } \\
\text { compound }\end{array}$ \\
\hline \multicolumn{5}{|l|}{ Mwila K, 2013} \\
\hline $\begin{array}{l}\text { In vitro assay: } \\
\text { enzymatic } \\
\text { detection } \\
\text { method using }\end{array}$ & $\begin{array}{l}\text { In vitro assay : enzymatic } \\
\text { detection method using }\end{array}$ & $\begin{array}{l}\text { In vitro assay: } \\
\text { enzymatic } \\
\text { detection method } \\
\text { using }\end{array}$ & & \\
\hline \multicolumn{5}{|l|}{ Du L., 2014} \\
\hline $\begin{array}{l}\text { In vivo, } \\
\text { male Wistar rats }\end{array}$ & $\begin{array}{l}\text { Dichlorvos, dimethoate, } \\
\text { acephate, phorate }\end{array}$ & $\begin{array}{l}\cdot 1 \mathrm{x}, 3 \mathrm{x}, \text { and } 9 \mathrm{x} \\
\text { NOAEL } \\
\text { - Drinking water } \\
\text { - } 24 \text { weeks }\end{array}$ & $\begin{array}{l}\text { Metabonomics } \\
\text { in plasma }\end{array}$ & $\begin{array}{l}\text { Joint toxic action at } \\
\text { the NOAEL of each } \\
\text { pesticide }\end{array}$ \\
\hline \multicolumn{5}{|c|}{ Baskar R., 2014} \\
\hline $\begin{array}{l}\text { In vivo, albino } \\
\text { Swiss mice }\end{array}$ & $\begin{array}{l}\text { Commercial formulation } \\
\text { Tatamida ( } 17.8 \% \\
\text { Imidacloprid), Uthane M- } \\
45 \text { ( } 75 \% \text { Mancozeb) }\end{array}$ & $\begin{array}{l}\text { - } 0.5 \% \text { LD50 } \\
\text { - Diet exposure } \\
\text { through lactation } \\
\text { - Analysis in } \\
\text { offspring at PND } \\
28 \text { and } 63 \\
\end{array}$ & $\begin{array}{l}\text { Metabolic } \\
\text { impact, weight } \\
\text { gain, cholesterol, } \\
\text { TG, thyroid } \\
\text { hormone }\end{array}$ & $\begin{array}{l}\text { Cumulative response } \\
\text { of the mixture }\end{array}$ \\
\hline \multicolumn{5}{|c|}{ Roustan A., 2014} \\
\hline $\begin{array}{l}\text { In vitro, } \\
\text { CHOK1 cells }\end{array}$ & $\begin{array}{l}\text { Glyphosate atrazine } \\
\text { AMPA DEA }\end{array}$ & $\begin{array}{l}5,10,50, \text { and } 100 \\
\mu \mathrm{g} / \mathrm{ml} \\
3 \mathrm{H}\end{array}$ & $\begin{array}{l}\text { Cytogenetic } \\
\text { potential }\end{array}$ & $\begin{array}{l}\text { Enhanced } \\
\text { cytogenetic activities }\end{array}$ \\
\hline
\end{tabular}


Figure 1

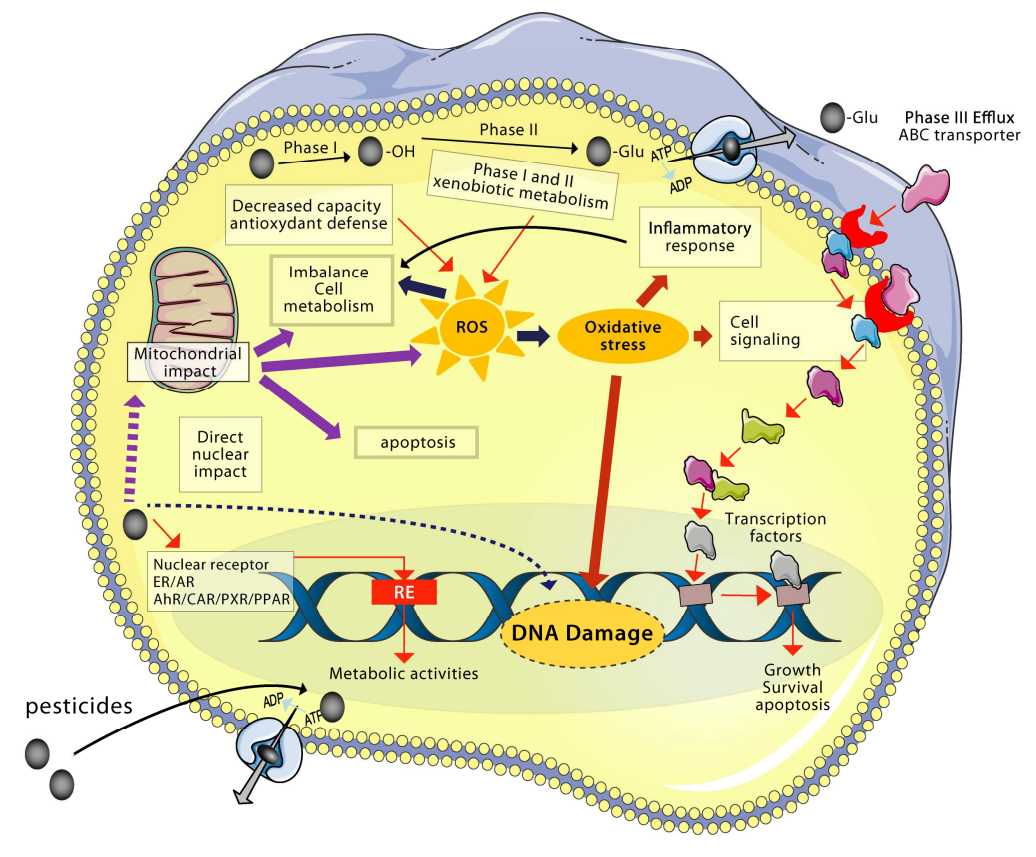

